\title{
A C. G. Jung Bibliography A Selection of Books, Articles and Reviews (1970-2018)
}

\author{
Compiled by Florent SERINA
}

This essay, which lists the main publications dedicated to the history of C. G. Jung's psychology, does not claim to be exhaustive. Nevertheless, it aims to provide a very broad overview of the historiography, from 1970 - the year Henri F. Ellenberger's reference work was published - to the present. This selection, which is to be updated annually, is likely to contain errors and possible gaps. Readers are invited to report them by sending us an email at the following address:

Dieser Aufsatz, der die wichtigsten Veröffentlichungen zur Geschichte der Psychologie von C. G. Jung auflistet, erhebt keinen Anspruch auf Vollständigkeit. Dennoch soll ein sehr breiter Überblick über die Geschichtsschreibung zu diesem Thema von 1970 - dem Jahr der Veröffentlichung des Nachschlagewerks von Henri F. Ellenberger - bis heute gegeben werden. Diese Auswahl, die jährlich aktualisiert werden soll, dürfte dennoch Fehler und mögliche Lücken enthalten. Die Leser sind eingeladen, sich mit Ergänzungen und Korrekturen zu melden, indem sie uns eine EMail an die folgende Adresse senden:

Cet essai qui recense les principales publications dédiées à l'histoire de la psychologie de C. G. Jung n'a pas de prétention à l'exhaustivité. Il n'en dresse pas moins un très large panorama de l'historiographie sur la question, de 1970 - date de la publication de l'ouvrage de référence d'Henri F. Ellenberger - à aujourd'hui. Cette sélection, appelée à être mise à jour annuellement, est malgré tout susceptible de comporter des erreurs, de même que d'éventuelles lacunes. Les lecteurs et lectrices sont invité.es à les signaler en nous adressant un courriel à l'adresse suivante:

Questo saggio, che elenca le principali pubblicazioni dedicate alla storia della psicologia di C. G. Jung, non pretende essere esaustivo. Tuttavia, si propone di fornire un'ampia panoramica della storiografia sull'argomento, dal 1970 - data di pubblicazione dell'opera di riferimento di Henri F. Ellenberger - fino ai giorni nostri. Questa selezione, che sarà aggiornata annualmente, può tuttavia contenere errori e possibili lacune. I lettori sono invitati a segnalarli inviandoci un'e-mail al seguente indirizzo: 


\section{0}

Books

ELLENBERGER, Henri F. The Discovery of the Unconscious. The History and Evolution of Dynamic Psychiatry, 1970.

Italian translation: La scoperta dell'inconscio. Storia della psichiatria dinamica, Torino: Boringhieri, 1972, translated by F. Mazzone

German translation: Die Entdeckung des Unbewussten, Bern, Stuttgart, Wien: Hans Huber, 1973, translated by G. Theusner-Stampa.

French translation: Histoire de la découverte de l'inconscient, Paris: Fayard, 1994, translated by J. Feisthauer.

WEHR, Gehrard. C. G. Jung in Selbstzeugnissen und Bilddokumenten. Reinbek: Rowohlt, 1970.

English translation: Portrait of Jung: an illustrated biography, New York: Herder and Herder, 1971.

Articles

CARLSSON, Allan. 'Jung on meaning and symbols in religion', The Journal of General Education 22, 1 (1970): 29-40.

Hillmann, James. 'A introductory note: C. G. Carus - C. G. Jung.' Carl Gustav Carus.' In CARus, Carl Gustav. Psyche. On the Development of the Soul, Dallas, Spring Publications, 1970: VII-XIV.

KRAWIEC, Theophile Stanley. 'A talk with (or listening to) Carl Jung.' Journal of Clinical Psychology 26, 4 (October 1970): 547.

MCCLINTOCK, James I. 'Jack London's use of Carl Jung's psychology of the unconscious.' American Literature 42, 3 (1970): 336-47.

QuiSPEL, Gilles Christiaan. 'Jung und die Gnosis: Die Septem sermones ad mortuos und Basilides.' Eranos Jahrbuch 1968, 37 (1970): 277-98.

\section{1}

$\underline{B o o k s}$

JAFFé, Aniela. From the Life and Work of C. G. Jung. New York: Harper \& Row, 1971.

Articles

MCGuire, William. 'Footnotes on Jung and transcendentalism.' Spring: An Annual Journal for Archetypal Psychology and Jungian Thought (1971): 136-140. 
BALMER, Heinrich. Die Archetypentheorie von C. G. Jung. Eine Kritik, Berlin, Heidelberg: Springer, 1972.

BENNET, Edward A. What Jung Really Said. New York: Schocken Books, 1972.

French translation: Ce que Jung a vraiment dit, Paris: Stock, translated by M. Salzmann, 1973.

VON FrAnZ, Marie-Louise, C. G. Jung: sein Mythos in unserer Zeit, Frauenfeld, Stuttgart:

Verlag Huber, 1972.

Italian translation: Il mito di Jung, Torino: Boringhieri, 1972, translated by E. Schanzer and L. Aurigemma.

Kennedy.

English translation: C. G. Jung: His Myth in Our Time, New York: Putnam, 1975, translated by W. H.

French translation: C. G. Jung. Son mythe en notre temps, Paris: Buchet/Chastel, 1975, translated by É. Perrot.

Olney, James. Metaphors of Self. A Theory of Autobiography, Princeton: Princeton University Press, 1972; London: Oxford University Press, 1972.

WEHR, Gerhard. C. G. Jung und Rudolf Steiner: Konfrontation und Synopse. Frankfurt am Main: Ullstein, 1972.

English translation: Jung \& Steiner: the Birth of a New Psychology. London: Temple Lodge, 1993; Great Barrington: Anthroposophic Press, 2002, translated by H. Erhard Lauer.

Articles

HeISIG, James W. 'The Septem Sermones: Play and theory.' Spring: An Annual Journal for Archetypal Psychology and Jungian Thought (1972): 206-18.

Hillmann, James. 'Dionysos in Jung's writings.' Spring: An Annual Journal for Archetypal Psychology and Jungian Thought (1972): 191-205.

JAFFÉ, Aniela. 'The creative phases in Jung's life.' Spring: An Annual Journal for Archetypal Psychology and Jungian Thought (1972): 162-90.

KELLER, Tina. 'C. G. Jung. Some memories and reflections.' Inward Lights 35, (1972): 118.

1973

$\underline{B o o k s}$

JAFFÉ, Aniela. Die schöpferischen Phasen im Leben von C. G. Jung. Leiden: Brill, 1973.

Progroff, Ira. Jung's Psychology and Its Social Meaning. New York: Anchor Books, 1973. 
Progroff, Ira. Jung, Synchronicity, E Human Destiny Noncasual Dimensions of Human Experience, New York: Julian Press, 1973.

Serrano, Miguel. El circulo hermético: de Hermann Hess a C. G. Jung, Buenos Aires: Editorial Kier, 1973.

Singer, June. Boundaries of the Soul: The Practice of Jung's Psychology, Garden City, New York: Anchor Press, 1973.

StORR, Anthony. C. G. Jung. New York: Viking Press, 1973; London: Fontana/Collins, 1973.

$\underline{\text { Articles }}$

Arens, Robert. 'C. G. Jung and some far Eastern Parallels.' CrossCurrents 23, 1 (1973): 73-91.

AurigemmA, Luigi. 'Carl Gustav Jung. Esquisse d'une œuvre.' Annales. Économies, Sociétés, Civilisations 28, 2 (1973): 343-67.

CARLSSON, P. Allan. 'Jung and James on the typology of world views.' The Journal of General Education 25, 2 (1973): 113-19.

HeIsig, James W. 'Jung and Theology: A Bibliographical essay.' Spring: An Annual of Archetypal Psychology and Jungian Thought (1973): 204-255.

ODAJNyk, Walter. 'The political ideas of C. G. Jung.' The American Political Science Review 67, 1 (1973): 142-52.

WALSER, Hans. 'Johann Jakob Honegger (1885-1911): Ein Beitrag zur Geschichte der Psychoanalyse.' Schweizer Archiv für Neurologie, Neurochirugie und Psychiatrie 112 (1973): 107-13.

\section{4}

Books

FreY-RoHn, Liliane. From Freud to Jung: A Comparative Study of the Unconscious. New York: Putnam, 1974.

KAST, Verena. Kreativität in der Psychologie von C. G. Jung. Zürich: Juris-Verlag, 1974.

MCGuIRE, William. 'Introduction.' In The Freud/Jung Letters. The Correspondence between Sigmund Freud and C. G. Jung. Princeton, Princeton University Press, Bollingen Series XCIV, 1974: xiii-xxxvii. 
German translation: 'Einleitung.' In Sigmund Freud, C. G. Jung. Briefwechsel. Frankfurt Am Main: S. Fischer Verlag: XI-XXXVII, 1974, translated by W. Sauerländer.

Italian translation: 'Introduzione.' In Lettere tra Freud e Jung 1906-1913. Torino, Paolo Boringhieri, 1974: XIVXXXIV, translated by M. Montinari, and S. Daniele.

French translation: 'Introduction.' In Correspondance Sigmund Freud - Carl Gustav Jung. Paris, Gallimard, 1975: 7-33, translated by R. Fivaz-Silbermann.

Rovigatti, Franca and Simonetta BetTi, Giorgio Petrocchi. Jung e la cultura europea: convegno tenuto a Roma dal 21 al 24 maggio 1974. Roma: Istituto della enciclopedia italiana, 1974.

WeHR, Gerhard. Wege zu religiöser Erfahrung: analytische Psychologie im Dienste der Bibelauslegung. Olten : Walter, 1974.

\section{Articles}

DOURLEY, John P. 'Trinatarian Models and Human Integration: Jung and Tilich Compared.' Journal of Analytical Psychology 19, 2 (July 1974): 131-50.

FitZPATRicK, William P. 'The Myth of Creation: Joyce, Jung, and Ulysses.' James Joyce Quarterly 11, 2 (1974): 123-44.

FoOTE, Edward. 'Who was Mary Foote.' Spring. An Annual of Archetypal Psychology and Jungian Thought (1974): 256-68.

FORDHAM, Michael. 'Jung's conception of transference.' Journal of Analytical Psychology 19, 1 (January 1974): 1-21.

SPICER, Malcolm. 'La Trinité: essai sur Jung.' Studies in Religion/Sciences Religieuses 3, 4 (1974): 299-319.

WALSER, Hans. 'An early psychoanalytic tragedy: J. J. Honegger and the beginnings of training analysis.' Spring: An Annual of Archetypal Psychology and Jungian Thought (1974): 243-55.

WheElWright, Joseph J., 'Jung and Freud speak to each other.' Psychological Perspectives 5, 2 (1974): 171-76.

\section{5}

$\underline{B o o k s}$

CoHEn, Edmund D., C. G. Jung and the scientific attitude, New York: Philosophical Library, 1975.

Stich, Hans. C. G. Jung und die Transzendenz. München: Ludwig-MaximiliansUniversitat, 1975. 
VAN DER POST, Laurens. Jung and the Story of Our Time, New York: Pantheon Books/RandomHouse, 1975.

WenR, Gerhard. C. G. Jung und das Christentum. Olten, Freiburg im Breisgau: Walter, 1975.

Odajnyk, Wolodymyr Walter. C. G. Jung und die Politik. Stuttgart: Ernst Klett Verlag, 1975 .

Zumstein-Preiswerk, Stephanie. C. G. Jungs Medium: Die Geschichte der Helly Preiswerk. Munich: Kindler Verlag, 1975.

\section{Articles}

ADLER, Gerhard. 'Aspects of Jung's personality.' Psychological Perspectives 6, 1 (Spring 1975): 11-21.

FORDHAM, Michael. 'Memories and Thoughts about C. G. Jung.' Journal of Analytical Psychology 20, 2 (1975): 102-13.

HARDING, Esther. 'Conversations with Jung: 1922-1961.' Quadrant: The Journal of the C. G. Jung Foundation 8, 2 (Winter 1975): 7-20.

Henderson, John L. 'C. G. Jung: a reminiscent picture of his method.' Journal of analytical psychology 20, 2 (July 1975): 114-21.

KIRSCH, James. 'Remembering C. G. Jung.' Psychological Perspectives 6, 1 (Spring 1975): $54-63$.

ScHWYZER, Hans-Rudolf. 'The intellect in Plotinus and the archetypes of C. G. Jung.' Kephalaion: studies in Greek philosophy (1975): 214-22.

SloAne, William. 'Jung and Rhine.' Quadrant: The Journal of the C. G. Jung Foundation 8, 2 (Winter 1975): 73-5.

VEIT, Ilza. 'Freud, Jung and Paracelsus: Historical Reflections.' Perspectives in Biology and Medicine 18, 4 (1975): 513-21.

Wolff-WindegG, Philip. 'C. G. Jung, Bachofen Burckhardt, and Basel.' Spring: An Annual for Archetypal Psychology and Jungian Thought (1975): 137-47.

WheElWright, Joseph B. 'A personal experience of Jung.' Psychological Perspectives 6, 1 (Spring 1975): 64-73.

ZELler, Max. 'The task of the analyst.' Psychological Perspectives 6, 1 (Spring 1975): 748. 


\section{6}

Books

HannAH, Barbara, Jung: His Life and Work. A Biographical Memoir. New York: G. P. Putnam's Sons, 1976.

Italian translation: Vita e opere di C. G. Jung, Milano: Rusconi, 1980, translated by F. Saba Sardi.

German translation: C. G. Jung. Sein Leben und Werk. Fellbach: Bonz Verlag, 1982, translated by L. Schwarz.

French translation: Jung sa vie et son œuvre. Paris: Dervy-Livres 1989, translated by M. Bacchetta.

Odajnyk, Walter. Jung and Politics: The Political and Social Ideas of C. G. Jung, foreword by Marie-Louise von Franz. New York: Harper \& Row, 1976.

VAN DER POST, Laurens. Jung and the History of Our Time. London: The Hogart Press, 1976.

Stern, Paul J. C. G. Jung: The Haunted Prophet. New York: George Braziller, 1976, NewYork: Delta Book/Dell Publishing, 1977.

German translation: C. G. Jung: Prophet des Unbewussten: eine Biographie. München, Zurich: Piper, 1977.

\section{Articles and reviews}

Ellenberger, Henri F. 'Review of Edmund D. Cohen, C. G. Jung and the Scientific Atittude.' Canadian Psychiatric Association Journal 21, 2 (1976): 130-31.

GRINNEL, Robert. 'Jung at Yale.' Spring: An Annual for Archetypal Psychology and Jungian Thought (1976): 155-6.

HiLlmanN, James. 'Some early background to Jung's ideas: Notes on C. G. Jung's medium, by Stefanie Zumstead-Preiswerk.' Spring: An Annual for Archetypal Psychology and Jungian Thought (1976): 128-36.

KIRSCH, Thomas B. 'The practice of multiple analyses in analytical psychology.' Contemporary Psychoanalysis 12, 2 (1976): 159-67.

PORTMAnN, Adolf. 'Jung's biology professor: some recollections.' Spring: An Annual for Archetypal Psychology and Jungian Thought (1976): 148-54.

ScotT-MaXwelL, Florida. 'Early Memories of Jung.' Inward Light 36 (1976): 30-4. 


\section{7}

Books

CAROtenuto, Aldo. Jung e la cultura italiana. Roma: Astrolabio, 1977.

JAFFÉ, Aniela. C. G. Jung: Bild und Wort. Olten: Walter Verlag, 1977.

English translation: C. G. Jung: Word and Image. Princeton: Princeton University Press, 1979.

KeInTZEL, Raimar. C. G. Jung: Ergebnisse seiner Psychologie: eine Kritik anhand des Begriffs der "psychischen Inflation". Bonn: Bouvier 1977.

Vincie, Joseph F. and Margarita Rathbauer-Vincie. C. G. Jung and Analytical Psychology: A Comprehensive Bibliography. New York, London: Garland, 1977.

\section{$\underline{\text { Articles }}$}

AvEns, Roberts. 'The image of the devil in C. G. Jung's psychology.' Journal of Religion and Health 16, 3 (1977): 196-222.

JAfFé, Aniela. 'Jung and the Eranos Conferences.' Spring: An Annual for Archetypal Psychology and Jungian Thought (1977): 201-12.

SMITH, Robert C., 'Empirical science and value assumptions: Lessons from C. G. Jung.' Journal of Religion and Health 16, 2 (1977): 102-09.

VON DER HEYDT, Vera. 'Jung and religion.' Journal of Analytical Psychology 22, 2 (April 1977): $175-83$.

VAN DER LEEUW, Pieter Jakob. 'The impact of Freud-Jung correspondence on the history of ideas.' International Review of Psychoanalysis 4 (1977):349-62.

English translation: 'Uber die wissenschaftsgeschichtliche Bedeutung des Briefwechsels zwischen Freud und Jung.' Psyche 31, 11 (November 1977): 1021-1044.

\section{8}

$\underline{B o o k s}$

BROME, Vincent. Jung: Man and Myth, London: Macmillan; New York: Atheneum, 1978.

Articles

COWARD, Harold G. 'Jung's encounter with yoga.' Journal of Analytical Psychology 23, 4

(October 1978): 339-57. 
McGuire, William. 'Jung in America, 1924-1925.' Spring: An Annual for Archetypal Psychology and Jungian Thought 9 (1978): 37-53.

WeHR, Gerhard. 'Carl Gustav Jung: die Frage nach der "Wirklichkeit der Seele”.' Mann bis Johannes XXIII (1978): 474-91.

\section{9}

$\underline{\text { Books }}$

HeISIG, James W. Imago Dei. A Study of C. G. Jung's Psychology of Religion. Lewisburg: Bucknell University Press; London: Associated University Press, 1979.

Homans, Peter. Jung in Context: Modernity and the Making of Psychology. Chicago, London: University of Chicago Press, 1979.

JAfFÉ, Aniela. Aus C. G. Jungs Welt: Gedanken und Politik. Zurich: Classen, 1979.

\section{$\underline{\text { Articles }}$}

COCKS, Geoffrey. 'C. G. Jung and the German Psychotherapy, 1933-1940. A research note.' Spring. An Annual of Archetypal Psychology and Jungian Though (1979): 221-27.

Grossman, Stanley. 'C. G. Jung und National Socialism.' Journal of European Studies 9, 36 (1979): 231-59.

\section{0}

$\underline{B o o k s}$

Carotenuto, Aldo. Diario di una segreta simmetria. Sabina Spielrein tra Jung e Freud. Roma, Astrolabio, 1979.

French translation: Sabina Spielrein: entre Freud et Jung. Paris: Aubier Montaigne, 1981, translated by M. Armand, M. B. de Launay et P. Rusch.

English translation: A Secret Symmetry: Sabina Spielrein Between Jung and Freud. The Untold Story of the Woman Who Changed the Early History of Psychoanalysis. New York: Pantheon Books, 1982; London: Routledge, 1984. German translation: Tagebuch einer heimlichen Symmetrie. Sabina Spielrein zwischen Jung und Freud. Freiburg im Breisgau: Kore, 1986.

Champernowne, Irene. A Memoir of Toni Wolff. San Francisco: C. G. Jung Institute of San Francisco, 1980. 
BOE, John. 'Jack London, the Wolf and Jung.' Psychological Perspectives 11, 2 (1980): 133-6.

TAYLOR, Eugene. 'Jung and William James.' Spring: A Journal for Archetypal Psychology and Jungian Thought 20 (1980): 157-69.

\section{1}

Books

ReChSteineR, Peter. Carl Gustav Jung und die Geschichte. Zürich: Zentralstelle der Studentenschaft, 1981.

Articles

GRAS, Vernon W. 'Myth and the reconciliation of opposites: Jung and Lévi-Strauss.' Journal of the History of Ideas 42, 3 (July-September 1981): 471-88.

JARRETT, James. 'Schopenhauer and Jung.' Spring: A Journal of Archetype and Culture (1981): 193-205.

SCHeidHAueR, Marcel. 'Un problème épineux entre Freud et Jung: le rêve.' Revue d'histoire et de philosophie religieuse LXI, 4 (1981): 413-25.

\section{2}

$\underline{B o o k s}$

FERNE, Jensen (ed.). C. G. Jung, Emma Jung, and Toni Wolff. A Collection of Remembrances. San Francisco: Analytical Psychology Club of San Francisco, 1982.

HoElLER, Stefan. The Gnostic Jung and the Seven Sermons to the Dead. Wheaton, 1982. German translation: Der gnostische Jung und die Sieben Reden an die Toten. Calw: Schatzkammer-Verlag, 1984, translated by H. Ullrich.

SteELE, Robert S. Freud and Jung: Conflicts of Interpretation. London, Boston: Routledge \& Kegan Paul, 1982.

WeHR, Gerhard, Portrait of Jung: an Illustrated Biography. Bundoora: Borchardt Library, 1982; republished as An Illustrated Biography of C. G. Jung. Boston, Shaftesbury: Shambhala Publications, 1989. 
GunTER, Pete A. Y. 'Bergson and Jung.' Journal of the History of Ideas 43, 4 (1982): 63552.

Humbert, Élie Georges. 'Jung et l'interrogation religieuse.' Cahiers de psychologie jungienne $34\left(3^{\mathrm{e}}\right.$ trimestre 1982): 27-46.

RITTMEISTER, John. 'Voraussetzungen und Konsequenzen der Jungschen Archetypenlehre.' Psyche-Zeitschrift für Psychoanalyse 36, 11 (1982): 1032-44.

WITZIG, James S. 'Théodore Flournoy, a friend indeed.' The Journal of Analytical Psychology 27, 2 (1982): 131-48.

Points out that in addition to introducing uniquely Jungian concepts, Flournoy provided Jung with the moral support and professional contact for the crucial period following the break with Freud. It is suggested that Flournoy deserves attention as being a major factor in the development of analytical psychology.

\section{3}

$\underline{B o o k s}$

Hogenson, George B. Jung's Struggle with Freud. Notre Dame, London: University of Notre Dame Press, 1983.

Rollins, Wayne G. Jung and the Bible. Atlanta: John Knox Press, 1983.

$\underline{\text { Articles }}$

GoODrich, Chauncey S. Jr., 'Transatlantic Dispatches From and About Zurich' Spring: A Journal of Archetype and Culture (1983): 183-90.

HoHL, Reinhold. 'C. G. Jung on Picasso (and Joyce).' Source: Notes in the History of Art 3, 1 (1983): 10-8.

MCGuIRE, William. 'Jung's seminars.' Quadrant: The Journal of the C. G. Jung Foundation 16, 1 (Spring 1983): 29-37.

Jung's seminars, in which he expounded his psychological ideas and his analytical methods as well as his views on society, the individual, religion, history and much more, have been known to only a few even among Jung's followers. The classes of auditors were limited, and the multigraphed transcripts, prepared by devoted seminar members, were not published but were circulated privately to a restricted list of subscribers. The volumes of Seminar Notes (as they are properly caled) in special Jungian libraries have customarily been withheld from any reader not having an analyst's approval. Jungian publications contain occasional references to the Notes but seldom quotations. Although the policy of restriction had Jung's consent, he eventually agreed to the inclusion of the Seminar Notes among his published works.

MCGuIRE, William. 'Jungian New York.' Quadrant: The Journal of the C. G. Jung Foundation 16, 1 (Spring 1983): 39-44

When did it all begin? I believe that the first tiny spark, the prima scintilla, was struck around 189o, when a Basel schoolboy named Carl Jung first studied English. Then, in early 1903, Dr. C. G. Jung took leave of his post at the Burghölzli Hospital and spent two months in London, practicing the language and haunting the art galleries. That was 
a wise decision: American and British psychiatrists were turning up in Zürich for postgraduate study. Burghölzli, with its association tests, psychoanalysis, and remarkable collection of Swiss psychotics, was the place for a refresher course. The first Americans Jung met were probably the New Yorkers Peterson and Brill, who had residencies at the hospital, and a New York delegation including Dr. Smith Ely Jelliffe that came to the American Congress in 1907. Jung invited the New York doctors to drop in later at the Burghölzli, and so they did. Over the sober teacups of Dr. Bleuler's establishment, one can imagine young Carl listening eagerly as the visitors talked of New York and its stimulations.

\section{4}

$\underline{B o o k s}$

JAFFÉ, Aniela. Jung's Last Years and Other Essays. Dallas: Spring Publications, 1984.

Papadopoulos, Renos K., and Graham S. SaAyman (eds.). Jung in Modern Perspective. Hounslow: Wildwood House, 1984.

Articles, and introductions

CHANG, M. Joseph, 'Jung and Lévi-Strauss: Whose Unconscious?' Mankind Quarterly 25, 1-2 (1984): 101-14.

CifALI, Mireille. 'Le fameux couteau de Lichtenberg.' Le Bloc-notes de la psychanalyse 4 (1984): 171-88.

HAULE, John. R. 'From somnambulism to the archetypes: the French roots of Jung's split from Freud.' Psychoanalytic Review 71, 4 (December 1984): 635-59.

JAFFÉ, Aniela. 'Details about C. G. Jung's family.' Spring: A Journal of Archetype and Culture (1984): 35-44.

McGuire, William. 'Introduction.' In JunG, C. G. Dream Analysis. Notes of the Seminar given in 1928-1930. Princeton, Princeton University Press, 1984: vii-xvi.

German translation: 'Einleitung.' In JUNG, C. G. Traumanalyse: nach Aufzeichnungen der Seminare 1928-1930, Olten: Walter Verlag, 1991: 7-17, translated by B. Stein.

French translation: 'Introduction.' In JUNG, C. G. L'Analyse des rêves. Notes du séminaire de 1928-1930, vol. 1. Paris: Albin Michel, 2005: 17-29, translated by J.-P. Cahen.

MCGUIRE, William. 'Jung's complex reactions (1907). Word association experiments performed by Binswanger.' Spring: A Journal of Archetype and Culture (1984): 134 .

Contends that L. Binswanger administered 2 word-association tests to Jung in 1907. A translation is reproduced of the tests, with Binswanger's comments preceding, interpolated in, and following the association lists. A repentance complex, a love of travel, a wish for a son, the father's death, concern over money, restlessness with the asylum, and a complex about Goethe are revealed in the 1st test; in the 2nd test, Jung speaks of a female patient who had slandered him. 


\section{5}

Books

Bennet, Edward. A. Meetings with Jung: Conversations Recorded by During the Years 1946-1961. London: Anchor Press, 1982.

COWARD, Harold. Jung and Eastern Thought. Albany: State of University of New York Press, 1985 .

SAMUELS, Andrew. Jung and the Post-Jungians. London and Boston: Routledge \& Kegan Paul, 1985.

WeHR, Gerhard. Carl Gustav Jung: Leben, Werk, Wirkung. Munich: Kšsel Verlag 1985. English translation: Carl Gustav Jung A Biography. Boston, London: Shambhala Publications, 1987.

French translation: Carl Gustav Jung: sa vie, son oeuvre, son rayonnement. Paris: Librairie de Médicis, translated by Dominique Taffin-Jouhaud and Martine Blondel, 1993.

Articles

LEYS, Ruth. 'Meyer, Jung, and the limits of association.' Bulletin of the History of Medicine 59, 3 (Fall 1985): 345-6o.

\section{6}

$\underline{B o o k s}$

MoACANIN, Radmila. Jung's Psychology and Tibetan Buddhism: Western and Eastern Paths to the Heart. London, Wisdom Publications, 1986.

SAmuels Andrew and Bani Shorter, Fred Plaut. A Critical Dictionary of Jungian Analysis. Londres, New York: Routledge, 1986.

STEIN, Murray. Jung's Treatment of Christianity: the Psychotherapy of a Religions Tradition. Wilmette: Chiron Publications, 1986.

Book chapters

TAYLOR, Eugene. 'C. G. Jung and the Boston psychopathologists.' In LATHROP, Daniel E. Mark Stern, and Karen GiBSON (eds.). Carl Jung and Soul Psychology. New York: Haworth Press (1986): 131-44. 


\section{7}

Books

Evers, Tilman. Mythos und Emanzipation. Eine kritische Annäherung an C. G. Jung. Hamburg: Junius, 1987.

Articles and book chapters

Carotenuto, Aldo. 'Jung's shadow problem with Sabina Spielrein.' In Mattoon, Mary Ann (ed.). The Archetype of Shadow in a Split World. $10^{\text {th }}$ International Congress of Analytical Psychology, Berlin 1986. Zürich: Daimon Verlag, 1987: 241-6o.

DiecKmann, Hans. 'Die Analytische Psychologie im Institut für Psychotherapie von den Anfängen bis heute.' In Institut für Psychotherapie. Dokumentation 40Jahrfeier Institut für Psychotherapie E. V. Berlin. Berlin, 1987: 1-5.

HOPCKE, Robert H. 'Jung's attitudes toward homosexuality : a review.' Spring (1987): 154-61.

MCCully, Robert S., 'Remarks on the last contact between Freud and Jung. A letter to the editor', Quadrant: The Journal of the C. G. Jung Foundation XX (1987): 73-4.

\section{8}

$\underline{B o o k s}$

DonN, Linda. Freud and Jung: Years of Friendship, Years of Loss. New York: Charles Scribner's Sons/Macmillan Publishing Co., 1988.

German translation: Freud und Jung. Biographie einer Auseinandersetzung. Hamburg: Kabel Verlag, 1988, translated by M. Benthack.

Italian translation: Jung e Freud? Anni di amicizia, anni di distacco. Milano: Leonardo, 1989, translated by S. French translation: Freud et Jung, de l'amitié à la rupture. Paris, Presses Universitaires de France, 1995, translated by P.-E. Dauzat.

Hurwitz, Emanuel. Otto Gross, Paradies-Sucher zwischen Freud und Jung. Suhrkamp Taschenbuch: Zürich, 1988.

Trevi, Mario. L'altra lettura di Jung. Milano: Raffaello Cortina Editore, 1988. 
DALAL, Farhad. 'Jung: a racist.' British Journal of Psychotherapy 4, 3 (1988): 263-81.

The paper examines Jung's perception of the non-European. It is argued that his perception of black people is racist and that these same views permeate the entire fabric of Jung's psychological theory. Further, that these views are woven into the theoretical foundations of two major Jungian concepts: the Collective Unconscious and Individuation. Finally, the paper examines the consequences of these theories as perceived by Jung, in terms of the possibilities or otherwise of people of different races living together.

DitTrich, Karin A. 'Freud, Jung und die Psychoanalytische Bewegung.' Psyche Zeitschrift für Psychoanalyse 42 (1988): 19-43.

JARETT, James L. 'Introduction.' In JunG, C. G. Nietzsche’s Zarathustra. Notes of the Seminar given in 1934-1939, vol. 1. Princeton: Princeton University Press, Bollingen Series XCIX, 1988: ix-xxi.

NiLL, Peggy. 'Die Versuchung der Psyche: Selbstwerdung als schöpferisches Prinzip bei Nietzsche und C. G. Jung.' Nietzsche-Studien 17 (1988): 250-79.

\section{9}

$\underline{B o o k s}$

HOPCKE, Robert H. Jung, Jungians, and Homosexuality. Boston: Shambhala, 1989.

JAFFÉ, Aniela. Was C. G. Jung a Mystic? and Other Essays. Einsiedeln: Daimon Verlag, 1989.

ROLFE, Eugene. Encounter with Jung. Boston: Sigo Press, 1989.

Segaller, Stephen, and Merrill Berger. The Wisdom of the Dream: The World of C. G. Jung, Boston: Shambhala Publications, 1989.

WeHr, Gerhard. Carl Gustav Jung. Arzt - Tiefenpsychologe - Vsionär: eine Bibliographie. Zurich: Schweizer Verlaghaus, 1989.

\section{Articles and introductions}

Douglas, Claire. 'Christiana Morgan's visions reconsidered: a look behind the Vision Seminars.' The San Francisco Jung Institute Library Journal 8, 4 (1989): 5-27.

McGuire, William. 'Introduction.' In JunG, C. G. Analytical Psychology. Notes of the Seminar given in 1925. Princeton: Princeton University Press, 1989: vii-xvi.

German translation: 'Einleitung.' In JUNG, C. G. Analytische Psychologie: nach Aufzeichnungen des Seminars 1925. Solothurn, Düsseldorf: Walter Verlag, 1995: 7-18, translated by H. Egner.

French translation: 'Introduction.' In JUNG. C. G. Introduction à la psychologie jungienne. Le séminaire de psychologie analytique de 1925, Paris: Albin Michel, 2015: 31-46, translated by K. Hainsworth and V. Thibaudier. 
RovatTI, Pier Aldo. 'Metafora e simbolo nella lettura junghiana del testo onirico. Una discussione.' Aut-aut 229-230 (January-April 1989): 65-84.

RovatTI, Pier Aldo. 'Riflessioni sull'ombra.' Aut-aut 229-230 (January-April 1989): 99110.

\section{0}

Books

AzIz, Robert. C. G. Jung's Psychology of Religion and Synchronicity. Albany: State University of New York Press, 1990.

BARNABY, Karin, and Pellegrino D’ACIERnO (eds.). Jung and the Humanities. Princeton: Princeton University Press, 1990.

BouTtes, Jean-Louis. Jung. La puissance de l'illusion. Paris: Éditions du Seuil, 1990.

Douglas, Claire. The Woman in the Mirror: Analytical Psychology and the Feminine. Boston: Sigo Press, 1990.

MAGgY, Anthony. The Valkyries: The Women Around Jung. Shaftesbury: Element Books, 1990.

SchulTZ, Duane. Intimate Friends, Dangerous Rivals: The Turbulent Relationship between Freud and Jung. Los Angeles: Jeremy P. Tarcher, 1990.

Articles

NAGY, Marilyn. 'Self and Freedom in Jung's Lecture on Ritschl.' Journal of Analytical Psychology 35 (October 1990): 443-57.

Pietist and Kantian themes asserting the priority and authority of individual experience over all kinds of public regulation of that experience informed Jung's psychological thinking about the self in its earliest phase. They remained central to his psychology, and may find new relevance in the late twentieth century, as increasing institutionalisation of all sectors of society threatens our freedom. Recent work by Michel Foucault parallels Jung's thinking in this respect. While Jung must be credited with being the first to describe the experience of the self in psychological terms, most of the features of his concept are richly available in the historical and cultural materials of his own immediate background. I have focused in this paper on just those sources which were used by Jung in his earliest work on the self, and have attempted to provide ample textual evidence. But I have counted on the reader's own familiarity with Jung's theory in its later phases to supply the exact parallels, so as not to be too lengthy. We should not overlook the fact that Ritschl's goal of 'priestly lordship over the world', which is achieved by an act of obedience and identification with social institutions is another type of self theory. Though such a theory would be highly unpopular today, Ritschl's theory has roots going back through the history of western spirituality to the Stoic doctrine of apatheia. The literature contains many reports attesting to the success of these methods. This is an open field for research. Although Jung would later in his life write about the emergence of the self as the result of the product of meaningful relationship, and here I think especially of his profound monograph, Psychology of the transference, it is even here the moment of death in the symbolic imagery of the Rosarium series which is the significant turning point in the development of the individual. The inevitable failure of relationships marked by projective identification makes it possible for the self to emerge. We must of course, said Jung, be projectively connected to each other and to social institutions at certain periods of our lives, and in order to get psychological processes going in the first place. But the real self appears only when we become estranged from collective institutions, when we have to struggle to be free, to be ourselves. 
Shamdasani, Sonu. 'A Woman called Frank.' Spring: A Journal of Archetype and Culture 50 (1990): 26-56.

\section{1}

$\underline{B o o k s}$

Maidenbaum, Aryeh, and Stephen A. MArTin (eds.). Lingering Shadows: Jungian, Freudians, and Anti-Semitism. Boston, London: Shambhala, 1991.

NaGY, Marilyn. Philosophical Issues in the Psychology of C. G. Jung. Albany: State University of New York Press, 1991.

NANNEN, Els. Carl Gustav Jung der getriebene Visionär. Berneck: Schwengeler-Verlag, 1991.

VON DER TANn Matthias, and Arvid ERLENMEIER (eds.). C. G. Jung und der Nationalsozialismus. Texte und Daten. Im Auftrag der Deutschen Gesellschaft für Analyt-ische Psychologie. Berlin: Deutschen Gesellschaft für Analytische Psychologie, 1991.

Articles

Ellenberger, Henri F. 'The story of Helene Preiswerk. A critical study with new documents.' History of Psychiatry 5, 1 (March 1991): 41-52.

Reconsiders the life of H. Preiswerk, the young medium who was the subject of Jung's (1902) dissertation, Zur Psychologie und Pathologie sogenannter occulter Phänomene. Jung observed that the young woman's possessing spirits represented 2 opposed aspects of her personality, between which she oscillated. Jung described Preiswerk as struggling against the barriers that impeded the development of her personality. This was the early formulation of the process he later called individuation. The story of Jung and Preiswerk's relationship as revealed in a more recent biography of Preiswerk by her niece, S. Zumstein-Preiswerk (1975), as well as in the intertwined family histories of the Jungs and Preiswerks, is quite different from Jung's account. The importance of placing Preiswerk's mediumistic performances in the sociocultural context and occult milieu of the late 19th century is emphasized.

INNAMORATI, Marco. 'La presenza dello Zarathustra di Nietzsche nelle opere di Jung.' Giornale storico di psicologia dinamica 29 (1991): 73-93.

MaIllard, Christine. 'L'idée d'un dépassement du christianisme dans l'œuvre de Carl Gustav Jung. Des Sept Sermons aux Morts (1916) à Mysterium coniunctionis (1955-1956).' Le Texte et l'Idée 6 (1991): 107-22.

TAYLOR, Eugene. 'C. G. Jung in his intellectual setting: the Swedenborgian connection.' Studia Swedenborgiana 7 (1991): 47-69. 
TILANDER, Ake. 'Why did C. G. Jung write his autobiography?' Journal of Analytical Psychology 36, 4 (1991): 111-24.

Discusses Jung's autobiography and considers its usefulness as an analysis of the psycho-history of Jung and his psychological development. It is noted that the autobiography contains subjective experiences and not facts about Jung's psycho-history. An accurate picture of Jung's life and psychological development can be obtained only when his autobiography is combined with other biographies. The value of the autobiography is reduced by certain obstacles that have to be taken into account during such analysis. Jung's work is 'contaminated' by his theories, and his description of his relationship with Freud is one-sided. Also, Jung wrote only a part of the aubiography himself.

1992

$\underline{B o o k s}$

CLARKE, John J. In Search of Jung: Historical and Philosophical Enquiries. London, New York: Routledge, 1992.

Dyer, Donald R. Cross-Currents of Jungian Thought: An Annotated Bibliography, Shambhala Publications, 1991.

RosenzWeIG, Saul. Freud, Jung, and Hall the King-Maker: The Historic Expedition to America, 1909. St Louis: Rana House Press, 1992.

UlANOV, Barry. Jung and the Outside World. Wilmette: Chiron, 1992.

\section{Articles}

Cunningham, Adrian. 'Victor White, John Layard and C. G. Jung.' Harvest: Journal for Jungian Studies 38 (1992): 44-57.

DiTTRICH, Karin A. 'Der "Heldenmythos” Hitler. Jungs späte Auseinandersetzung mit Freud und der Psychoanalyse.' Luzifer-Amor. Zeitschrift zur Geschichte der Psychoanalyse 5, 9 (1992): 57-69.

ERlenmeyer, Arvid. 'Jung und die Deutschen.' Analytische Psychologie 23 (1992): 133161.

Hoffer, Peter T. 'The concept of phylogenetic inheritance in Freud and Jung.' Journal of the American Psychoanalytic Association 40, 2: (1992): 517-30.

At the height of their collaboration in late 1911, Freud had succeeded in persuading Jung of the role of phylogenetic factors in the etiology of neuroses and psychoses. Phylogenetic considerations play an important part in the formulation of Jung's genetic standpoint of psychology with its conception of a desexualized primal libido, which figured prominently in the dispute which ended the relations between Freud and Jung. Freud's unpublished draft of 'Overview of the Transference Neuroses' was in part an attempt to counter Jung's revisions of libido theory by using phylogenetic considerations to reaffirm his original conception of a unified sexual libido. Despite the sharp divergence of many aspects of their respective psychologies after the break, a conception of phylogenetic inheritance continued to play an important role in their developing theoretical formulations.

MaILlard, Christine. 'Le divin et la féminité. À propos de la sophiologie de Carl Gustav Jung.' Revue d'histoire et de philosophie religieuses 72, 4 (1992): 427-44. 
Noll, Richard. 'Jung the Leontocephalus.' Spring: An Annual of Archetypal Psychology and Jungian Thought 53 (1992): 12-6o.

SAmuels, Andrew. 'National Psychology, National Socialism, and Analytical Psychology. Reflections on Jung and anti-semitism.' Journal of Analytical Psychology 37 (1992): 3-28.

The paper is a critical study of the intellectual relations of analytical psychology and national socialism. I try to show that it was Jung's attempt to establish a psychology of nations that brought him into the same frame as Nazi anti-semitic ideology. In addition, Jung was absorbed by the question of leadership, also a pressing issue during the 1930s. Exploring these ideas as thoroughly as possible leads to a kind of reparation, for I think that post-Jungians do have reparation to make. Then it is possible to revalue Jung's overall project in more positive terms. By coupling a less simplistic methodology and a more sensitive set of values to Jung's basic intuitions about the importance of a psychology of cultural difference, analytical psychology has something to offer a depth psychology that is concerned with processes of political and social transformation.

French translation: 'Psychologie nationale, national-socialisme et psychologie analytique: réflexions sur Jung et l'antisémitisme.' Revue d'histoire internationale d'histoire de la psychanalyse 5, 1992, 183-219.

SHAmDASANI, Sonu. 'Two unknown early cases of Jung.' Harvest: Journal for Jungian Studies 38 (1992): 38-43.

1993

Books

CHARET, Francis Xavier. Spiritualism and the Foundations of C. G. Jung's Psychology. Albany: State University of New York Press, 1993.

Douglas, Claire. Translate this Darkness: The Life of Christiana Morgan. New York: Simon \& Schuster, 1993.

Fordham, Michael. The Making of an Analyst. A Memoir. London: Free Association Books, 1993.

HÖFER, Renate. Die Hiobsbotschaft C. G. Jungs, Folgen sexuellen Missbrauchs. Lüneburg: Zu Klampen Verlag, 1993.

KERR, John. A Most Dangerous Method. The Story of Jung, Freud, and Sabina Spielrein. New York: Knopf, 1993.

German translation: Eine höchst gefährliche Methode. Freud, Jung und Sabina Spielrein. München: Kindler, 1994, translated by C. Broermann and U. Schäfer.

MaIllard, Christine. Les Sept Sermons aux Morts. Du plérome à l'Étoile. Nancy: Presses Universitaires de Nancy, 1993.

BISHOP, Paul. 'The Jung/Förster-Nietzsche Correspondence.' German Life and Letters 46 (1993): 319-30. 
ELMS, Alan. 'The auntification of Jung.' Uncovering Lives: The Uneasy Alliance of Biography and Psychology. New York: Oxford University Press, 1993: 51-70.

MindER, Bernard. 'Jung an Freud 1905: ein Berich über Sabina Spielrein.' Gesnerus: Swiss Journal of the history of medicine and sciences 50, 1-2 (1993): 113-20.

SAmuels, Andrew, with the collaboration of Sonu Shamdasani, Gottfried HeUer, and Matthias VON DER TANN. 'New material concerning Jung, anti-Semitism and the Nazis.' Journal of Analytical Psychology 38, 4 (October 1993): 463-70.

SHAMDASANI, Sonu. 'Spielrein's associations: A newly identified word association protocol.' Harvest: Journal for Jungian Studies 39 (1993): 164-68.

SHAMDASANI, Sonu. 'Automatic writing and the discovery of the unconscious.' Spring: A Journal of Archetype and Culture 54 (1993): 100-31.

\section{4}

$\underline{B o o k s}$

Clarke, John James. Jung and Eastern Thought: A Dialogue with the Orient. London, New York: Routledge, 1994.

COnRAD Lammers, Ann. In God's Shadow: The Collaboration of Victor White and C. G. Jung. New York, Mahwah: Paulist Press, 1994.

McGowAN, Don. What is Wrong with Jung. Amherst: Prometheus Books, 1994.

Ljunggren, Magnus. The Russian Mephisto: A Study of the Life of Emilii Medtner. Stockholm, Almqvist \& Wiksell International, 1994.

Noll, Richard. The Jung Cult: Origins of a Charismatic Movement. Princeton: Princeton University Press, 1994.

RYCE-MenuHIN, Joel. Jung and the Monotheisms: Judaism, Christianity and Islam. London, New York: Routledge, 1994.

\section{$\underline{\text { Articles }}$}

BISHOP, Paul. 'Jung's annotation of Nietzsche's works: an analysis.' Nietzsche-Studien 24 (1995): 271-314.

BISHOP, Paul. 'The members of Jung's seminar on Zarathustra.' Spring: A Journal of Archetype and Culture 56 (1994): 92-122. 
DONAT, James G. 'Is depth psychology really deep? Reflections on the history of Jungian psychology.' Harvest: Journal for Jungian Studies 40, 1994: 193-208.

Dourley, John P. 'The implications of C. G. Jung's critique of the symbole of trinity.' Studies in Religion/Sciences Religieuses 23, 4 (1994): 441-55.

MAILlard, Christine. 'C. G. Jung et la pensée allemande. L'intégration de l'impensée : les Sept Sermons aux Morts (1916).' Cahiers jungiens de psychanalyse 79 (1994): $75-88$.

Minder, Bernard. 'Sabina Spielrein. Jungs Patientin am Burghölzli.' Luzifer-Amor Zeitschrift für Geschichte der Psychoanalyse 7 (1993): 55-127.

English translation: 'Sabina Spielrein: Jung's patient at the Burghölzli.' Journal of Analytical Psychology, 46 (1) (January 2001): 43-66.

SAmuels, Andrew. “A Jung Club is not enough”: the professionalisation of Analytical Psychology 1913-1957 and its implications for today.' Harvest: Journal for Jungian Studies 40 (1994): 155-67.

SAmuels, Andrew. 'Jung and antisemitism.' The Jewish Quarterly 41, 1 (Spring 1994): 5963.

SHAMDASANI, Sonu. 'Reading Jung backwards? The correspondence between Michael Fordham and Richard Hull concerning "The type problem in poetry" in Jung's Psychological Types.' Spring: A Journal of Archetype and Culture 55 (1994): 11027.

\section{5}

$\underline{B o o k s}$

De Angulo, Gui. The Old Coyote of Big Sur: The Life of Jaime de Angulo. Berkeley: Stonegarden Press, 1995.

Bishop, Paul, The Dionysan Self: C. G. Jung's Reception of Friedrich Nietzsche. Berlin, New York: Walter de Gruyter, 1995.

CArotenuto, Aldo. Jung e la cultura del XX secolo. Milano: Bompiani, 1995.

ROBERTSON, R. Jungian Archetypes: Jung, Gödel and the History of Archetypes. York Beach: Nicolas-Hays, 1995.

WEHR, Gerhard. Selbsterfahrung mit C. G. Jung. Freiburg im Breisgau: Verlag Herder, 1995 . 
Aeschbacher, Urs. 'C. G. Jung, das “Dritte Reich” und die Gewalt der Seele.' In MAtTioli, Aram (ed.). Intellektuelle von rechts Ideologie und Politik in der Schweiz 1918-1939. Zürich: Orell Füssli Verlag, 1995: 73-89.

GaILlard, Christian. 'Le regard presbyte de C. G. Jung.' Cahiers jungiens de psychanalyse 82 (printemps 1995): 103-18.

MAILlaRD, Christine. 'Fondation d'une psychologie sur des bases interculturelles: Vision et apport de l'Autre dans l'œuvre de C. G. Jung.' La Vouivre. Cahiers de psychologie analytique 5 (1995): 107-22.

MCGUiRE, William. 'Firm Affinities. Jung's relations with Britain and the United States.' Journal of Analytical Psychology 40 (1995): 301-26.

SHAmdasani, Sonu. 'Memories, dreams, omissions.' Spring: A Journal of Archetype and Culture 57 (1995): 115-37.

TAYLOR, Eugene. 'Transcendence and the intrapsychic universe.' San Francisco Jung Institute Library Journal 14, 1 (1995): 41-7.

Wilhelm, Hans Rudolf. 'Carl Gustav Jung: Promotionsakten. Dokumente aus dem Staatsarchiv des Kantons Zürich.' Sudhoffs Archiv 79, 2 (1995): 231-233.

Two documents dated 1902 show Eugen Bleuler as the supervisor of Carl Gustav Jung's thesis. In his expert opinion Bleuler declares himself convinced of the high scientific qualities of Jung.

\section{6}

$\underline{B o o k s}$

BrockWAY, Robert W. Young Carl Jung. Wilmette: Chiron Publications, 1996.

Gallant, Christine. Tabooed Jung: Marginality as Power. London: Macmillan, 1996.

MCLynN, Franck. Carl Gustav Jung. A Biography. New York: St. Martin’s Press, 1996.

PezzelLA, Mario. Lo spirito e l'ombra: i seminari di Jung su Nietzsche. Bergamo: Moretti \& Vitali, 1996.

Schoent, William. Major Issues in the Life and Work of C. G. Jung. Lanham: University Press of America, 1996.

TougAS, Gérard. C. G. Jung, de l'helvétisme à l'universalisme. Montréal: XYZ, Documents, 1996. 
WeHR, Gerhard. 'C. G. Jung und Eugen Böhler. Eine Begegnung in Briefen.' C. G. Jung und Eugen Böhler. Eine Begegnung in Briefen. Zürich: VDF Hochschulverlag AG an der ETH Zürich, 1996: 3-32.

Articles and book chapters

BisHOP, Paul. 'The use of Kant in Jung's early psychological works.' Journal of European Studies 26, 2 (1996): 107-40.

BishOP, Paul. 'C. G. Jung, Hans Trüb und die "Psychosynthese". Analytische Psychologie 27 (1996): 119-37.

MaIllard, Christine. 'L'apport de l'Inde à la pensée de Carl Gustav Jung.' Hulin Michel, and Christine MAILlARD (eds.). L'Inde inspiratrice. Réception de l'Inde en France et en Allemagne (XIX-XXe siècle). Strasbourg: Presses Universitaires de Strasbourg, 1996: 71-82.

MAILlard, Christine. 'Phénoménologie du psychisme et vision du réel chez C. G. Jung.' Cahiers philosophiques de Strasbourg (mars 1996): 71-82.

NEWMAN, William R. “Decknamen or pseudochemical language?" Eirenaeus Philalethes and Carl Jung.' Revue d'histoire des sciences 49, 2 (1996): 159-88.

Rosen, David. 'If only Jung had had a rabbi.' Journal of Analytical Psychology 41 (1996): 245-56.

SAmuels, Andrew. 'Jung's return from banishment.' The Psychoanalytic Review 83, 4 (1996): 469-89.

SHAMDASANI, Sonu. 'De Genève à Zurich: Jung et la Suisse romande.' Revue médicale de la Suisse romande 116 (1996): 917-22.

SHAMDASANI, Sonu. 'Should this remain? Anna Freud's misgivings concerning the Freud-Jung Letters', in MAHONY Patrick, Carlo BonOMI, and Jan STEnson. Behind the Scenes: Freud in Correspondence. Oslo: Scandinavian University Press, 1996: 357-68.

TAYLOR, Eugene. 'The New Jung Scholarship.' The Psychoanalytic Review 83, (1996): 547-68.

Wilhelm, Hans Rudolf. 'Carl Gustav Jung's Curriculum Vitae from the Year 1902.' Bulletin of the History of Medicine 70, 2 (Summer 1996): 296-302. 
GEBHARDT, Richard, Jung und der deutsche Faschismus. München: GRIN Verlag Gmb, 1997.

Noll, Richard. The Aryan Christ: The Secret Life of Carl Jung. New York: Random House, 1997.

PALMER, Michael. Freud and Jung on Religion. London, New York: Routledge, 1997.

SchmitT, Gerhart. Zyklus und Kompensation. Zur Denkfigur bei Nietzsche und Jung, Frankfurt am Main: Peter Lang, 1997.

Young-Eisendrath, Polly, and Terence Dawson (eds.). The Cambridge Companion to Jung. Cambridge: Cambridge University Press, 1997; $2^{\text {nd }}$ edition 2008.

Articles and introductions

BISHOP, Paul. 'The Descent of Zarathustra and the Rabbits: Jung's Correspondence with Elisabeth Förster-Nietzsche.' Harvest 43, 1, 1997: 108-23.

Douglas, Claire. 'Introduction.' In JunG, C. G. Visions. Notes of the Seminar given in 1930-1934. London: Routledge, 1997, ix-xxxiii.

French translation: 'Introduction.' In JUNG, C. G. L'Analyse des visions. Le séminaire de 1930-1934. Paris: La Compagnie du Livre Rouge, Imago, 2018: 13-40, translated by B. Eveno.

KINGS, Steven. 'Jung's Hermeneutics of Scripture.' The Journal of Religion 77, 2 (April 1997): 233-51.

MAIllard, Christine. 'De la Nature de l'inconscient. Carl Gustav Jung et le paracelsisme.' Cahiers jungiens de psychanalyse 88 (printemps 1997): 1-13.

TACEY, David. 'Jung in the academy: devotions and resistances.' Journal of Analytical Psychology 42, 4 (October 1997): 269-83.

Jung's position in the contemporary mainstream English-speaking university is problematical indeed. For various historical and ideological reasons, Jung is generally not included in the courses in academic psychology, and in the humanities and social sciences his reception is lukewarm to say the least. He has only a marginal place in religious studies. This notorious academic resistance to Jung is compensated, some would say overcompensated, by student interest and enthusiasm, which sometimes seeks to make a religious dogma out of Jung's psychology. In a sense, cynical resistance to Jung and fanatical devotion to Jung can be seen to generate each other in a sort of binary opposition. This situation is unfortunate because neither extreme presents a fair or balanced view of Jung's thought or of his contribution to intellectual history. These and other problems associated with the teaching of Jung in a university setting are briefly outlined in this paper. 


\section{8}

Books

Schoent, William. C. G. Jung : his Friendship with Mary Mellon and J. B. Priestley, Wilmette: Chiron Publications, 1998.

SHAmDASAni, Sonu. Cult fictions. C. G. Jung and the Founding of Analytical Psychology. London, New York: Routledge, 1998.

Italian translation: Fatti e artefatti. Su C. G. Jung, sul Club Psicologico e su un culto che non è mai esistito, Roma: Magi Edizioni, 2004.

Articles and book chapters

Bishop, Paul. 'On the History of Analytical Psychology: C. G. Jung and the Rascher Verlag.' Seminar 34, 3 (September 1998): 256-79; Ibid. 34, 4 (November 1998): 364-87.

LYONS, Roger. 'My experience with C. G. Jung.' Harvest 44, 2 (1998): 137-57.

MAILlaRD, Christine. 'Le rêve dans la psychologie analytique de Carl Gustav Jung.' Cahiers de la FNEY (1 ${ }^{\mathrm{er}}$ trimestre 1998): 125-44.

MAILlard, Christine. 'La fin des mondes divins, de Schiller à Jung.' La Vouivre. Cahiers de psychologie analytique 8 (1998): 3-14.

MAIllard, Christine. 'Présence de la mystique baroque dans l'œuvre de Carl Gustav Jung.' PAUl, Jean-Marie (ed.) : L'Homme baroque. Nancy: Presses Universitaires de Nancy, 1998: 211-22.

MARTINEZ, Thomas J., and Eugene TAYLOR. "Yes, in You the Tempest Rages": the archetypal significance of America in Jung's own process of individuation.' Spring: A Journal of Archetype and Culture 64 (Fall/Winter 1998): 32-56.

PIETIKÄINEN, Petteri. 'National typologies, races and mentalities in C. G. Jung's Psychology.' History of European Ideas 24, 6 (1998): 359-73.

RouDinESCO, Elisabeth. 'Carl Gustav Jung: de l'archétype au nazisme. Dérives d'une psychologie de la difference.' L'Infini 63 (1998): 73-94.

SHAMDASANI, Sonu. 'The lost contributions of Maria Moltzer to analytical psychology: two unknown papers.' Spring: A Journal of Archetype and Culture 64 (1998): 10320.

SPRINGER, Anne. 'Jung in Berlin. Geschichtliche und gruppendynamische Anmerkungen.' Analytische Psychologie 29 (1998): 1-17. 
TACEY, David. 'Jung and the New Age: a study in contrasts.' The Round Table Press Review (April 1998): 1-11.

TAYLOR, Eugene. 'Jung before Freud, not Freud before Jung: the reception of Jung's work in American psychotherapeutic circles between 1904 and 1909.' Journal of Analytical Psychology 43, 1 (January 1998): 97-114.

A review is first presented of the new Jung scholarship - that Jung is to be properly understood, not as a disciple of Freud, but as the twentieth century exponent of the symbolic hypothesis in the tradition of the late nineteenth century psychologies of transcendence. This is followed by an outline of the so-called French-Swiss-English and American psychotherapeutic alliance, of which Jung was a part, and the cross-cultural mediumistic psychology of the subconscious it promoted, chiefly through the works of William James, F. W. H. Myers, and Théodore Flournoy. Focusing on the experimental work of the Swiss-American pathologist Adolph Meyer and the American neurologist Frederick Peterson, evidence is then produced to show that Jung, before Freud, was more important in American psychotherapeutic circles. His experimental researches into the association method and the psychogalvanic reflex, his study of mediums and connection to Swiss psychiatry had numerous unique alliances with the American scene, particularly because of their similar historical relation between psychology and religion. Therefore, to understand Jung, one must consider the archetypal significance which America held for Jung's own individuation process, as well as the Americanization of Jungian ideas that followed.

\section{9}

$\underline{B o o k s}$

Bishop, Paul (ed.). Jung in Contexts. London, New York: Routledge, 1999.

DIXON, Patricia E. Nietzsche and Jung: Sailing a Deeper Night. New York, Washington D.C., Baltimore, Boston, Bern, Frankfurt am Main, Berlin, Wien, Paris: Peter Lang, 1999.

EllwoOD, Robert S. The Politics of Myth: A Study of C. G. Jung, Mircea Eliade, and Joseph Campbell. Albany: State University of New York Press, 1999.

HAYMAN, Ronald. A Life of Jung, London: Bloomsbury, 1999.

PietikëInen, Petteri. C. G. Jung and the Psychology of Symbolic Forms. Helsinki: Finnish Academy Sciences, 1999.

RoccI, Giovanni. La maschera e l'abisso. Una lettura junghiana di Nietzsche. Roma: Bulzoni Editore, 1999.

Rowland, Susan. C. G. Jung and Literary Theory. Basingstoke: Macmillan, 1999.

YATES, Jenny. Encountering Jung. Jung on Death and Immortality. Princeton: Princeton University Press, 1999. 
BISHOP, Paul. 'Estrangement from the Deed and the Memory thereof: Freud and Jung on the pale criminal in Nietzsche's Zarathustra.' Orbis Litterarum 54 (1999): 424-38.

Lothane, Zvi. 'Tender love and transference: unpublished letters of C. G. Jung and Sabina Spielrein.' International Journal of Psycho-Analysis 8o, 6 (1999): 11891204.

PARKeS, Graham. 'Nietzsche and Jung: Ambivalent Appreciations.' In GolOMB, Jacob, Weaver SANTANiEllo, and Ronald LeHrer (eds.). Nietzsche and Depth Psychology, Albany: SUNY Press, 1999: 69-213.

SEGAL, Robert A. 'Is analytical psychology a religion? Rationalist and romantic approaches to religion and modernity.' Journal of Analytical Psychology 44, 4 (October 1999) 547-60.

The relationship between analytical psychology and religion is part of the larger issue of the relationship between modernity and religion. There are three main views on the issue. The fundamentalist position sets religion against modernity and opts for religion over modernity. What I call the 'rationalist' position likewise sets religion against modernity but opts for modernity over religion. By contrast to both views, what I call the 'romantic' position reconciles religion with modernity. Rationalists maintain that religion can exist only in so far as it serves as an explanation of the physical world, which the rise of science now precludes. Romantics maintain that religion, while serving as an explanation of the physical world till dislodge by science, is at heart anything but an explanation. The toppling of the religions explanation by the scientific one, far from dooming religion, prods religion into making explicit what it has in fact been all along. By this categorization, Jung is overwhelmingly a romantic. For him, the function of religion has always been more psychological than explanatory, and the rise of science does not preclude the continuing existence of religious myths as a psychological rather than an explanatory phenomenon. For those for whom science does spell the demise of religion, secular myths can replace religious ones, and those secular myths are more secular versions of religions myths than secular alternatives to religions myths. Yet even if for Jung religion can still exist today because religion is in fact psychology, it does not follow that psychology is therefore a religion.

SHAMDASANI, Sonu. 'Is analytical psychology a religion? In statu nascendi.' Journal of Analytical Psychology 44, 4 (October 1999): 539-45. and religion.

This paper elucidates and discusses Jung's conceptions of the relation between psychology, psychotherapy

STORR, Anthony. 'Is analytical psychology a religion? Jung's search for a substitute for lost faith.' Journal of Analytical Psychology 44, 4 (October 1999): 531-37.

Analytical psychology does not aim at curing neurotic symptoms, but at bringing about a change in the patient's attitude to him or her self, and therefore to life in general. This new attitude can be described as religious, but it has nothing to do with creeds or conventional forms of worship. Analytical psychology is not a religon, but can be described as a prolegomenon to religion or religion in statu nascendi.

2000

$\underline{B o o k s}$

BISHOP, Paul. Synchronicity and Intellectual Intuition in Kant, Swedenborg and Jung, Lampeter: Edwin Mellen Press Ltd, 2000.

CABOt ReID, Jane, Jung, My Mother and I: The Analytic Diaries of Catharine Rush Cabot, Einsiedeln: Daimon Verlag, 2000. 
Desvecovi, Pier Claudio. Il giovane Jung e il periodo universitario. Bergamo: Moretti \& Vitali, 2000.

DunE, Claire. Carl Jung Wounded Healer of the Soul: an Illustrated Biography, London: Parabola Books, 2000.

HAUKE, Christopher. Jung and the Postmodern: The Interpretation of Realities. London: Routledge, 2000.

KIRSCH, Thomas B. The Jungians. A Comparative and Historical Perspective, London: Routledge, 2000.

SPRECHER, Thomas (ed.). Das Unbewusste in Zürich. Literatur und Tiefenpsychologie um 1900 - Sigmund Freud, Thomas Mann und C. G. Jung. Zürich: Neue Zürcher Zeitung Verlag, 2000.

\section{Articles}

CHARET, Francis Xavier. 'Understanding Jung: recent biographies and scholarship.' Journal of Analytical Psychology 45, 2 (2000): 195-216.

The tendency to associate Jung with Freud has undergone a change and both are increasingly perceived as founders of depth psychological schools whose exact relationship is unclear. The separation of the two was largely due to Jung's rejection by the psychoanalytic community because of his perceived spiritual inclinations. Recent scholarship has emphasized these spiritual inclinations in both a positive and negative way and brought to light Jung's nonFreudian sources, while other Jungian practitioners are seeking a closer association with psychoanalysis. This conflicting development is related to tendencies in Jung himself that are evident in his own life and in research conducted into the writing and publication of Memories, Dreams, Reflections. Though the status of the latter as Jung's autobiography has been called into question there remains the necessity to explain the myth of Jung's life enshrined there and the impact this has had on a public looking for meaning in a time of considerable change.

PietikÄInen, Petteri. 'The Volk and its Unconscious: Jung, Hauer and the "German Revolution”.' Journal of Contemporary History 35, 4 (October 2000): 523-39.

This article examines the relationship between the Swiss psychiatrist and psychotherapist C.G. Jung and the German Indologist and volkisch scholar J.W. Hauer, with whom Jung collaborated in the early 1930s. In the latter part of the decade, Jung became increasingly wary of the political implications of volkisch doctrines and Hauer's volkisch ambitions, which reached their apotheosis in the founding of the German Faith Movement. There are two main reasons for Jung's increasing reluctance to co-operate with Hauer. First, as his public image was that of a neutral Swiss, Jung did not want to associate too closely with an openly National-Socialist scholar, whose racial ideas he no longer shared and whose influence in Germany was negligible anyway. Second, Jung had become more widely known in the AngloAmerican world during the 1930s, and he did not want to risk his growing reputation there by adhering too closely to openly volkisch doctrines. Yet, although the more explicit elements of volkisch ideology disappeared from his writings, in his infatuation with mythical archetypes, he retained some of the more invisible volkisch elements in his psychology.

SEGAL, Robert A. 'Jung's very twentieth-century view of myth.' Journal of Analytical Psychology 48, 5 (November 2000): 593-617.

It is commonly assumed that Jung's view of myth, like his view of everything else, is best understood vis-à-vis Freud's. I argue that Jung in fact positions himself much more broadly, not merely against other psychologists of myth but more fundamentally against non-psychologists altogether. Undeniably, Jung pits his theory against Freud's, but only after pitting both his theory and Freud's against those theories that assume the subject matter of myth to be the external world rather than the human mind and that assume the function of myth to be either the explanation or the description of the external world rather than the expression of the human mind. The theorists whom Jung challenges are called 'nature mythologists', for whom myth is either a literal explanation or a symbolic description of the natural world. Which element of the natural world myth is about varies from nature mythologist to nature mythologist. The two leading nature mythologists, both of whom Jung cites, were Edward Tylor and James Frazer. Their theories epitomize the nineteenth-century approach to myth. For them, myth is the 'primitive' counterpart to science, which is entirely modern. For them, myth and science are incompatible, science is true and myth false, and myth must therefore 
go when science comes. Jung's rejection of the external world as the referent of myth and of explanation or description of that world as the function of myth epitomizes the twentieth-century response to nineteenth-century theories. For not merely Jung and Freud but also twentieth-century theorists generally, myth is anything but the 'primitive' counterpart to modern science. Consequently, myth and science are not rivals, so that myth need not go when science comes.

SHAMDASANI, Sonu. 'The magical method that works in the dark.' Journal of Jungian Theory and Practice V, 3 (2000): 15-8.

Italian translation: 'Il metodo magico che lavora in segreto: C. G. Jung, ipnosi e suggestione.' Rivista di psicologia analitica 75 (2007): 13-26.

SHAMDASANI, Sonu. 'Misunderstanding Jung: the afterlife of legends.' Journal of Analytical Psychology 45, 3 (July 2000): 459-72.

F. X. Charet's article, 'Understanding Jung: recent biographies and scholarship', is full of errors and legends. In this article, I demonstrate the tendentiousness of his criticisms of the historical work of Eugene Taylor and myself concerning Jung's linkages with the subliminal psychology of Théodore Flournoy, William James, and F. W. H. Myers, and the fallaciousness of his criticism of my claim that Memories, Dreams, Reflections was not Jung's autobiography.

\section{1}

\section{$\underline{B o o k s}$ and doctoral dissertations}

CABOt ReID, Jane. Jung, My Mother and I. The Analytic Diaries of Catharine Rush Cabot. Einseldeln: Daimon, 2001.

Casement, Ann. Carl Gustav Jung. London, Thousand Oaks, New Delhi: Sage Publications, 2001.

Puccioni Marasco, Patricia (ed.). Jung e l'ebraismo. Firenze: Giuntina, 2001.

TACEY, David. Jung and the New Age. London, New York: Brunner-Routledge, 2001.

WIESER, Annatina. Zur frühen Psychoanalyse in Zürich 1900-1914. Inaugural Dissertation Zur Erlangung der Doktorwürde der Medizinischen Fakultät der Universität Zürich, Medizinhistorisches Institut und Museum der Universität Zürich, 2001.

Articles, introductions, and book chapters

LUDWIG-KÖRNER, Christiane. 'Das Kinderheim in Kallinchen. Milla von Prosch geb. von Mücke.' In BernhardT, Heike, and Regine LOckOt (eds.). Mit ohne Freud. Zur Geschichte der Psychoanalyse in Ostdeutschland. Gießen: PsychosozialVerlag, 2000: 132-69.

GRAF-NOLD, Angela. 'The Zurich School of psychiatry in theory and practice. Sabina Spielrein's treatment at the Burghölzli Clinic in Zurich.' Journal of Analytical Psychology 46, 1 (January 2001): 73-104.

The remarkably caring and privileged treatment of Sabina Spielrein at the Burghölzli Hospital 1904/05 (as shown by the records) exemplifies the standards and key concepts of the Zürich School of Psychiatry, founded by Auguste Forel and represented by the then current director Eugen Bleuler, as well as the specific dynamics between Bleuler, his first assistant C. G. Jung, and Spielrein herself. Bleuler, in accordance with the trauma theory of hysteria, stead- 
fastly promoted the separation from her traumatizing family and supported her scientific education. Jung, deeply and emotionally involved, revealed how she had been traumatized, but in focusing on her masochistic feelings rather than on the victimization, he established a rather conflicted personal relationship with her, foreshadowing his later ambivalent attitude to Freud's sexual theory. Thus Sabina was discharged with a reasonable psychiatric and scientific education but an unreasonable need for personal dependency.

French translation: 'Sabina Spielrein à la Clinique psychiatrique du Burghölzli. Faits et fictions d'un traitement.' Le Coq-Héron 197 (2009): 41-62.

Heuer, Gottfried. 'Jung's twin brother. Otto Gross and Carl Gustav Jung. With an hitherto unpublished letter by C. G. Jung.' Journal of Analytical Psychology 46, 4 (October 2001): 655-88.

This paper is a preliminary communication of several years of research into the life and work of the Austrian psychoanalyst and anarchist Otto Gross (1877-1920). Although he played a pivotal role in the birth of modernity, acting as a significant influence upon psychiatry, psychoanalysis, ethics, sociology and literature, he has remained virtually unknown to this day. Following a biographical sketch and an overview of his main theoretical contributions, the impact of Gross' life and work on the development of analytical theory and practice is described. His relationship with some of the key figures in psychoanalysis is presented, with particular emphasis on his connections to Jung. The paper concludes with an account of relevant contemporary interest in his work: the founding of the International Otto Gross Society, the first edition of The Collected Works of Otto Gross on the Internet, and the ist and 2nd International Otto Gross Congresses which took place in Berlin in 1999 and at the Burghölzli Clinic, Zürich, in October 2000.

French translation: 'Otto Gross entre Freud et Jung. Histoire secrète du frère jumeau de Jung.' La Vouivre. Cahiers de psychologie analytique 13 (2003): 87-101.

Hogenson, George B. 'The Baldwin effect: a neglected influence on C. G. Jung's evolutionary thinking.' Journal of Analytical Psychology 46, 4 (October 2001): 591-611.

This paper considers the claim that C. G. Jung used a Lamarckian model of evolution to underwrite his theory of archetypes. This claim is challenged on the basis of Jung's familiarity with and use of the writings of James Mark Baldwin and Conway Lloyd Morgan, both of whom were noted and forceful opponents of neo-Lamarckian theory from within a neo-Darwinian framework. The paper then outlines the evolutionary model proposed by Baldwin and Lloyd Morgan, which has come to be known as Baldwinian evolution or the Baldwin effect. This model explicitly views psychological factors as central to the evolutionary process. Finally, the use of Baldwinian thinking in contemporary theorizing regarding language and other symbolic systems is reviewed and suggestions are made regarding the implications of Baldwinian models for theory building in analytical psychology.

Liebscher, Martin. “Wotan” und "Puer Aeternus”. Die Zeithistorische Verstrickung von C. G. Jungs Zarathustrainterpretation.’ Nietzsche-Studien 30 (2001): 329-50. English translation : "Wotan" and "Puer Aeternus": The historical context of C. G. Jung's interpretation of Zarathustra.' New Nietzsche Studies, 6, 3/4, 7, 1/2 (2006): 99-115.

LiEBSCHER, Martin. 'Jungs Abkehr von Freud im Lichte seiner Nietzsche-Rezeption.' Zeitenwende-Wertewende. Internationaler Kongreß der Nietzsche-Gesellschaft zum 100. Todestag Friedrich Nietzsches vom 24.-27. August 2000 in Naumburg, Protokollband des Naumburger Nietzsche-Kongresses. Berlin: Akademie Verlag, 2001: 255-60.

MAILlaRD, Christine. 'Aion. Zur Vorstellung einer nachchristlichen Zeit im Spätwerk C. G. Jungs.' In KNOBLOCH, Hans-Jörg, and Helmut KoOPMANN (eds.). Endzeitstimmungen in der deutschen Literatur. Tübingen: Stauffenburg-Verlag, 2001: 135-45.

MAILlaRD, Christine. 'Autobiographie als persönlicher Mythos: C. G. Jungs "Erinnerungen”.' In KNOBLOCH, Hans-Jörg, and Manfred Misch (eds.). Autobiographien als Zeitzeugen. Tübingen: Stauffenburg-Verlag, 2001: 61-75.

Traditional narratives of life appear either as a discourse of unveiling or as a discourse of mystification : the autobiographical subject breaks free from the past by giving it a shape and a boundary in discourse, and by hiding, sometimes deliberately, the unbearable or the shameful, if only by omission. This article offers a reading of Jung's biography (Memories, Dreams, Reflections, 1961) informed primarily by the question of the purpose and intentionality 
of writing, with an eye to how the autobiographical subject's purposes may have competed or collided with editor Aniéla Jaffé's, producing a complex web of intentionality seeking legitimacy and justification on the one hand, and a forum for a radical view of the tenets of Jung's work on the other.

French translation: “Le livre de Madame Jaffé”. Ma Vie de C. G. Jung: remémoration, légitimation, monumentalisation." Cahiers jungiens de psychanalyse 104 (automne 2002): 79-97.

MinDER, Bernard. 'Sabina Spielrein. Jung's patient at the Burghölzli.' Journal of Analytical Psychology 46, 1 (January 2001): 43-66.

MinDER, Bernard. 'A document. Jung to Freud 1905: a report on Sabina Spielrein.' Journal of Analytical Psychology 46, 1 (January 2001): 67-72.

A recently discovered letter, dated September 25, 1905, proves that Jung's first attempt to get in contact with Freud had taken place earlier than it had been assumed on the basis of their published correspondence. The letter contains a brief case history of Sabina Spielrein's illness. It was addressed to Freud and handed over to Sabina Spielrein's mother who intended to remove her daughter from Jung with whom the girl had fallen in love. However, the letter was never passed on to Freud.

SORGE, Giovanni. 'Prefazione. Divagazioni minime intorno al carteggio.' Lettere tra Ernst Bernhard e Carl Gustav Jung 1934/1959, Rivista di Psicologia Analitica. La biblioteca di Vivarium, 2001: 7-21.

2002

Books

Maidenbaum, Aryeh (ed.). Jung and the Shadow of Anti-Semitism. Berwick: NicolasHays, 2002.

RoAzen, Paul. The Trauma of Freud. Controversies in Psychoanalysis. New Brunswick: Transaction Publishers, 2002.

Lоскот, Regine. Erinnern und Durcharbeiten: zur Geschichte der Psychoanalyse und Psychotherapie im Nationalsozialismus. Gießen: Psychosozial-Verlag, 2002.

\section{Articles}

GAILlARD, Christian, 'L'“autobiographie” de Jung. Scènes, scénarios et lignes de force.' Topique. Revue freudienne 79 (été 2002): 153-73

English translation: "On defining words, some scenarios and vectors in the "autobiography" of C. G. Jung.' Journal of Analytical Psychology 48 (2003): 571-591.

LIEBSCHER, Martin. 'Zarathustra - Der Archetypus des "Alten Weisen".' Nietzscheforschung 9 (2002): 234-45.

Melanson, Steve. 'La thérapeutique jungienne, une voie de l'expérience religieuse.' Studies in Religion / Sciences Religieuses 31, 2 (2002): 159-70.

The factual experience of religion is of the utmost importance in Carl Gustav Jung's view. According to the psychoanalyst, comprehensive Psychotherapeutic healing requires the return to a 'religious attitude consistent with the individual.' Such an attitude is always consequential to an individual's inner religious experience. According to Jung, to experience religion is to undergo the union of the conscious and the unconscious, which lie at both ends of the psyche. The individual is led to this experience by a practice favouring the connection between the conscious and the uncons- 
cious. The effectiveness of this practice is governed by the law of enantiodromia, which describes the effect when a unilateral reality is pushed to its limit and reverses into its opposite. Thus, by assuming his or her unconscious, and the accompanying 'shadow,' the individual approaches the healing light. It is only when one is in the very darkness of the absolute evil carried by the 'shadow' that the individual is open to the experience of "meaning.'

MÖlLER, Arnulf, ScharfETter, Christian, Hell, Daniel. 'Development and termination of the working relationship of C. G. Jung and Eugen Bleuler, 1900-1909.' History of Psychiatry 13, 52 (2002): 445-53.

From 1900 to 1909 , C. G. Jung was on the staff of the University Psychiatric Clinic in Zurich ('Burghölzli'), headed by Eugen Bleuler, where he became a senior physician (Sekundararzt) in 1905. Jung received his doctorate (1902) and postdoctoral qualification as a university lecturer (Habilitation) based on Bleuler's reports to the department of medicine, and he continued to give lectures on certain recurring topics, such as the theory of hysteria, until summer semester 1914, well after his resignation. Minutes of department meetings that have not previously been evaluated appear to indicate that a major factor leading to Jung's resignation on 7 March 1909 was the department's rejection of the founding of the 'psychopathologic research laboratory' that he had expected. The importance of other events for Bleuler's relationship with Jung - the unsuccessful attempt at an analytical treatment of Otto Gross, and Jung's relationship with Sabina Spielrein - cannot be determined from current sources.

\section{3}

Books

BAIR, Deirdre. Jung. A biography. Boston: Little, Brown \& Co, 2003.

Covington, Coline, and Barbara Wharton (ed.). Sabina Spielrein Forgotten Pioneer of Psychoanalysis, Hove, New York, Brunner-Routledge, 2003.

MelansOn, Steve. Jung et la mystique. Vannes: Sully, 2003.

Shamdasani, Sonu. Jung and the Making of Modern Psychology. The Dream of a Science. Cambridge: Cambridge University Press, 2003.

Italian translation: Jung e la creazione della psicologia moderna. Il sogno di una scienza, Roma: Magi Edizioni, 2007.

$\underline{\text { Articles }}$

HAYNAL, André and Ernst FAlzEDER. 'Ferenczi and Jung: some parallel lines ?' Journal of Analytical Psychology 48, 4 (2003): 467-78.

In the complexity of the entangled interactions within the group of psychoanalytical pionneers, their divergent interests and views, the Ferenczi-Jung relationship is of particular interest given the importance that both had in the field of the history of ideas. It is striking to discover some parallel lines, but interpersonal, institutional and socio-cultural factors contributed to the fact that this peaceful and complementary collaboration was not possible in the long run. Perhaps for the present generation, in retrospective, it is easier to notice seminal strokes and also some deficiencies in all these thinkers.

KIRSCH, Thomas B., “Toni Wolff-James Kirsch correspondence.” Journal of Analytical Psychology 48, 4 (September 2003): 499-506.

This paper draws on the letters between Toni Wolff and James Kirsch from 1929-1933 and from 1949-1953 to highlight some aspects of Toni Wolff's relationship with her superviser and former analysand, James Kirsch. Her personality, her approach to her work as analyst, and her relationship with Jung and with colleagues are illustrated with selected quotes from the correspondence. 
KITANAKA, Junko. 'Jungians and the rise of psychotherapy in Japan: A brief historical note.' Transcultural Psychiatry 40, 2 (2003): 239-47.

LIARD, Véronique. 'C. G. Jung et le malaise social dans le monde occidental.' Sociétés 82, 4 (2003): 93-106.

LIEBSCHER, Martin. 'Die "unheimliche Ähnlichkeit”. Nietzsches Hermeneutik der Macht und analytische Interpretation bei Carl Gustav Jung.' Ecce Opus 81 (2003): 37-50.

MCGUIRE, William. 'Jung, Evans-Wentz and various other gurus.' Journal of Analytical Psychology 48, 4 (October 2003): 433-45.

How did Jung become deeply concerned with Asian religions and particularly with the Tibetan Buddhism of a Welshman from Trenton, New Jersey? Could that man be considered one of Jung's gurus? This essay begins six years after Jung, at twenty, was admitted to the medical school of Basel University and became a member of the Zofingiaverein, a student society. The next year he gave the first of a series of lectures on the interpretation of Christ as the model of the 'god-man', like the Apostle Paul, Confucius, Zoroaster and the Buddha, who was 'drummed into the Hindu boy'. (Jung's Zofingia Lectures were discovered only after his death, in 1961, and were published in English in 1983). The present essay discusses Jung's early Buddhist interest as displayed in The Psychology of the Unconscious (finally, in a revision, entitled Symbols of Transformation), in Psychological Types and later in his foreword of the Wilhelm translation of the I Ching. Jung was influenced by the gurus Richard Wilhelm and his son Hellmut, the scholar J. W. Hauer (with whom he later broke off relations because of Hauer's Nazi politics), the indologist Heinrich Zimmer, and the Zen master D. T. Suzuki. Walter Yeeling Wentz was born in Trenton in 1878 and brought up in his family's theosophist faith. The Wentzes moved to San Diego in 190o, and Walter added his mother's Celtic surname, Evans, to the German Wentz. He was educated at Stanford University and travelled in Europe, studying Celtic folklore, and widely in the Near East, Tibet, India, and Oxford - studying religions everywhere and editing Tibetan books. He lived his last decades in San Diego and conducted a correspondence with Jung, while living in a cheap hotel, or in an ashram.

Procesi, Lidia. 'C. G. Jung e l'imperialismo occidentale nel seminario sugli Esercizi Spirituali di Ignazio di Loyola.' Rivista di psicologia analitica 67, 15 (2003): 5984.

SANFORD, Drob. 'Towards a Kabbalistic Psychology: C. G. Jung and the Jewish Foundations of Alchemy.' Journal of Jungian Theory and Practice 5, 2 (2003): 77100.

Jung's use of Kabbalistic symbols and ideas as well as his personal Kabbalistic vision are critically examined. It is argued that as great as Jung's acknowledged affinity is to the Kabbalah, his unacknowledged relationship was even greater. Jung has been accused of being a contemporary Gnostic; however, the interpretations Jung placed on Gnosticism and the texts Jung referred to on alchemy were profoundly Kabbalistic, so much so that one would be more justified in calling the Jung of the Mysterium Coniunctionis and other late works a Kabbalist in contemporary guise. Although Jung, at least during the 1930s, appears to have had powerful motives that limited his receptivity to Jewish ideas, his highly ambivalent and at times reproachable attitude toward Judaism should not prevent one from appreciating the affinities between Jungian psychology and Jewish mystical thought.

\section{4}

$\underline{B o o k s}$

HUSKINSON, Lucy. Nietzsche and Jung, The Whole Self in the Union of Opposite. London, New York: Routledge, 2004.

VIELjeuX, Juliette (ed.). Jung. Catalogue chronologique des écrits. Paris: Cahiers jungiens de psychanalyse, 2004 . 
ZuCH, Rainer. Die Surrealisten und C. G. Jung: Studien zur Rezeption des analytischen Psychologie im Surrealismus am Beispiel von Max Ernst, Victor Brauner und Hans Arp. Weimar: VDG, 2004.

\section{Articles and books chapters}

LiNDENFELD, David. 'Two antimodern master narratives: Jung and Heidegger.' In MARChAnd, Suzanne, and David Lindenfeld (eds.). Germany at the fin de siècle. Culture, politics, and ideas. Baton Rouge: Louisiana State University Press, 2004: $287-311$.

NichOLS, M. 'A Bibliography of Jungian and Post-Jungian Literary Criticism: 1980200o.' In BAumlin, James S., Tina F. BAumlin, and George H. JEnSEN (eds.). PostJungian Criticism: Theory and Practice. Albany: State University of New York Press (2004): 263-95.

QuisPel, Gilles. 'Meetings with Jung.' In CowAN, Lyn (ed.). Barcelona 2004. Edges of Experience: Memory and Emergence. Proceedings of the 16th International IAAP Congress for Analytical Psychology. Einsiedeln : Daimon Verlag, 2004: 145-52.

WALDron, David, and Sharn WALDron. 'Jung and the Neo-Pagan Movement.' Quadrant: The Journal of the C. G. Jung Foundation XXXIV, 2 (2004): 29-46.

Neo-Paganism, one of the fastest-growing religious movements in the world today, has undergone a series of profound transformations in structure, belief, and symbolism over the past 50 years. One of the most significant is the appropriation of Jungian analytical psychology by broad sectors of the neo-Pagan movement and by some of its most eloquent proponents, such as Margot Adler, Miriam Simos, and Vivianne Crowley. However, the application of Jungian methodology as a means of legitimating religious belief is not as simple or unambiguous as neo-Pagan writers and conversely, critics of Jung such as Richard Noll, would attest. This paper explores the appropriation of Jungian theory by sectors of the neo-Pagan movement. It also examines the neo-Pagan movement's rather ambivalent relationship with Jung's interpretation of the human psyche within the broader context of western modernity.

Wolin, Richard. 'Prometheus Unhinged: C. G. Jung and the Temptations of Aryan Religion.' In Wolin, Richard (ed.). The Seduction of Unreason. The Intellectual Romance with Fascism, from Nietzsche to Postmodernism. Princeton, Oxford: Princeton University Press, 2004: 63-88.

\section{5}

Books

BERTIN, Georges, and Véronique LIARD. Les grandes images: lecture de Carl Gustav Jung. Laval, Les Presses de l’Université Laval, 2005.

Burleson, Blake Wiley. Jung in Africa. New York, London: Continuum, 2005.

GIESER, Suzanne. The Innermost Kernel: Depth Psychology and Quantum Physics. Wolfgang Pauli's Dialogue with C. G. Jung. Berlin, Heidelberg, New York: Springer 2005. 
Rowland, Susan. Jung as a Writer. Hove, New York: Routledge, 2005.

SHAMDASANI, Sonu. Jung Stripped Bare by his Biographers, Even. London: Karnac, 2005. Italian translation: Jung messo a nudo dai suoi biografi, Roma, Magi Edizioni, 2008.

\section{Articles and book chapters}

CAMBRAY, Joe. 'The place of the $17^{\text {th }}$ century in Jung's encounter with China.' Journal of Analytical Psychology 50, 2 (April 2005): 195-207.

After recounting several dreams and related alchemical interests of Jung's tied to the $17^{\text {th }}$ century, a contextualizing look at select scientific and philosophical developments of that century is presented. Several precursors of the contemporary debates on the mind/body relation are noted, with special reference to the work of Antonio Damasio. This in turn leads to a reconsideration of the work of the $17^{\text {th }}$ century polymath Gottfried Wilhelm Leibniz, which Jung read as a major precursor to his formulation of synchronicity (via Leibniz's concept of 'pre-established harmony'). Leibniz was the first philosopher to articulate the mind/body relationship in terms of supervenience, sharing an accord with those contemporary philosophers and scientists who see the mind as being an emergent property of the body-brain. Similarly, these ideas are also consistent with a reformulation of synchronicity in terms of emergence. Tracing Leibniz's interest in China reveals another set of links to Jung and to emergentism. Jung's use of Taoist concepts in developing the synchronicity principle is well known. According to scholars, Leibniz was the first major Western intellect to study the I-Ching, through the assistance of a Jesuit missionary in Beijing, Fr. Joachim Bouvet. Some details of the Leibniz-Bouvet correspondence are discussed here. Despite Helmut Wilhelm's presenting aspects of this correspondence at an Eranos conference, Jung does not appear to have integrated it into his writing on synchronicity - a possible reason for this omission is suggested.

DROB, Sanford. 'Jung's Kabbalistic Visions.' Journal of Jungian Theory and Practice 7, 1 (2005): 33-54.

Jung's 1944 kabbalistic visions are examined from the standpoint of Jung's earlier provocative remarks about Jewish psychology and National Socialism, his attitude towards the Jewish sources of his own theories, and from the perspective of both Jungian and kabbalistic dream theory. The author suggests that (1) Jung's visions signaled a change in his attitudes and personality that is critical to a full understanding of his complex relationship to Judaism, (2) the kabbalistic understanding of dreams highlights significant points of contact between Jewish mysticism and analytic psychology, and (3) Jung's own mystical interpretation of his kabbalistic visions raises important questions regarding his understanding of religious symbolism and the boundaries between psychological science and religious experience.

\section{Elms, Alan C. 'Jung's lives.' Journal of the History of the Behavioral Sciences 41, 4 (Fall 2005): 331-46. \\ Forty published life histories of C. G. Jung are grouped into eight categories: autobiography, hagiographies, pathographies, professional biographies, intellectual biographies, illustrated biographies, religious biographies, and joint Jung/Freud biographies. Each work is briefly reviewed in terms of its scope, its main contributions to the biogra- phical literature on Jung, and its principal shortcomings. A short list of selected readings on Jung's life is recommended.}

FALzeDER, Ernst. 'Sigmund Freud, Eugen Bleuler, C. G. Jung und das Burghölzli: Die Geschichte einer ambivalenten Beziehung.' In GÖTZ VON OlEnHUSEN, Albrecht and Gottfried Heuer (eds.). Die Gesetze des Vaters. 4. Internationaler Otto Gross Kongress. Marburg an der Lahn: LiteraturWissenschaft.de, 2005: 129-50.

Frosh, Stephen. 'Jung and the Nazis: Some Implications for Psychoanalysis.' Psychoanalysis E History 7 (2005): 253-70.

The involvement of Jung with German psychotherapy in the 1930s revealed a strong tendency to collaborate with the Nazis, even though his behaviour was more contradictory than has often been acknowledged. In part this was due to anti-Semitic sentiments; some of it was fueled by the apparent opportunity to make Jungian psychology dominant over its 'Jewish' Freudian rival; and in part Jung's admiration for the energy of the Nazi movement seems to have been genuine. This paper traces some of the elements in Jung's activities of that period in order to highlight the mixture of pragmatic and ideological investments that also applied to many other psychotherapists, and to some German psychoanalysts at the time. 
GRAF-NOLD, Angela. 'Swiss Federal Institute of Technology (ETH): Collating the text of the 'Modern psychology.' Jung History I, 1 (Spring 2005): 12-14.

Jeromson, Barry. 'Systema Munditotius and Seven Sermons: Symbolic collaborators in Jung's confrontation with the dead.' Jung History I, 2 (Winter 2005-2006): 7-10.

Liebscher, Martin: 'C. G. Jung. Die gedanklichen Werkzeuge des Unbewussten.' In BuchHolz, Michael B. and Günter GöDdE (eds.). Macht und Dynamik des Unbewussten. Berlin: Psychosozial-Verlag, 2005: 391-404.

De Moura, Vicente. 'Some critical issues about Jungian analysis.' Jung History I, 2 (Winter 2005-2006): 20-3.

SHAmDASANI, Sonu. 'Modern psychology.' Jung History I, 1 (Spring 2005): 8-11.

STEIN, Murray. 'Some reflections on the influence of Chinese thought on Jung and his psychological theory.' Journal of Analytical Psychology 50, 2 (April 2005): 20922.

Jung claimed that Richard Wilhelm, whose masterful translations of Chinese wisdom literature into a European language (German) and thence into Western consciousness have brought Chinese modes of thinking to so many, was one of the most important influences on his own life and work. The contacts between the two men, which took place from the early 1920's until Wilhelm's death in 1930, were few but intense and for Jung decisive in several ways. Wilhelm's translations of the I Ching and The Secret of the Golden Flower opened new avenues for Jung that had far-reaching consequences on his research and writing after 1930. The latter opened the door to the study of alchemy as a key to the archetypal process of individuation as rooted in the collective unconscious. 'Synchronicity' is a term that grew out of his contact with Chinese thought, in particular with the I Ching. From his contact with Chinese thought, additionally, he received confirmation of the view, independently arrived at, that adult psychological development is not linear but rather circular and spiral-like. The letters between Jung and Wilhelm illuminate the great importance Jung ascribed to Wilhelm's contribution toward bridging East and West and the potential value of Chinese philosophy for psychotherapy.

SwAn, Wendy. 'Tina Keller's analyses with C. G. Jung and Toni Wolff.' Jung History I, 2 (Winter 2005-2006): 11-5.

ZABRISKIE, Beverley. 'Synchronicity and the I Ching: Jung, Pauli, and the Chinese Woman.' Journal of Analytical Psychology 50 (April 2005): 223-35.

The capacity of the human mind to discover and invent both imagistic analogies and mathematical structures to represent reality is strikingly juxtaposed in the ancient Chinese text of the I Ching. Its emphasis on containing all sorts of opposites and its plastic appeal to multi-valenced experience has kept it alive through millennia and across cultures. Jung was introduced to its Taoist wisdom by the Sinologist Richard Wilhelm. The Nobel Laureate quantum physicist Wolfgang Pauli became familiar with its philosophy and mathematics through his reading of Schopenhauer and Leibniz. In their correspondence about the nature of the unconscious and synchronicity, Pauli and Jung also exchanged their musings on Pauli's dreams of a Chinese woman, her role in his psyche and his scientific theories 
Gundry, Marc R. Beyond Psyche: Symbol and Transcendence in C. G. Jung. New-York: Peter Lang, 2006.

Quaglino, Gian Piero, and Augusto Romano. A colazione da Jung. Milano: R. Cortina, 2006.

Articles

LiEBSCHER, Martin. 'Nietzsche und Jung, review of Lucy HusKinson, The Whole Self in the Union of Opposites.' Nietzsche-Studien 35 (2006): 393-397.

SwAN, Wendy. 'Tina Keller's analyses with C. G. Jung and Toni Wolff, 1915-1928.' Journal of Analytical Psychology 51, 5 (November 2006): 493-511.

This historical essay documents the clinical practices of C. G. Jung and Toni Wolff with their analysand Tina Keller, a Swiss physician and psychotherapist, during the formative years of analytical psychology (1915-1928). The topic is investigated through an examination of primary documents, largely unpublished, in English and German, based on Keller's autobiographical writings. It presents biographical information on Keller's life and details of her analyses with Jung and Wolff, emphasizing the technique of active imagination and describing the clinical practices of Jung and Wolff in Keller's analyses.

2007

Books

CASEMENT, Ann (ed.). Who Owns Jung? London: Karnac Books, 2007.

LiarD, Véronique. Carl Gustav Jung 'Kulturphilosoph'. Paris: Presses de l'Université Paris-Sorbonne, 2007.

PIETIKÄInEN, Petteri. Alchemists of Human Nature: Psychological Utopianism in Gross, Jung, Reich and Fromm. London: Pickering \& Chatto, 2007.

SwAN, Wendy. C. G. Jung and Active Imagination: a Case Study of Tina Keller. Saarbrücken: Verlag Dr. Müller, 2007.

Articles, introductions and book chapters

Conrad Lammers, Ann and Adrian Cunningham. 'Introduction.' In The Jung-White Letters. London, New York, Routledge, Philemon Series (2007): xxi-xxxi. 
DANIEL, Michele. 'Jung's Affinity for Buddhism: Misunderstandings and Clarifications.' Psychological Perspectives 50 (2007): 220-34.

Much of the West's understanding of Jung's thinking about Buddhism comes from reading his essays on Tibetan and Zen Buddhism, in which his commentary focuses upon particular doctrinal teachings of these two forms of Mahayana Buddhism. However, his writings about the figure of the Buddha and the Buddha's earliest sermons, as they are collected in the Pali Canon, are less well known. By looking closely at what Jung had to say about the Buddha, his early discourses, and his comments in other works that have a correspondence with these discourses, we can clarify some common misconceptions about Jung's thinking in this area. Such an examination offers a better understanding of Jung's depth of feeling for the essential teachings of the Buddha. In order to accomplish these aims, the article begins with a discussion of the historical and cultural background in which Jung was writing and his concerns about the West's infatuation with Eastern ideas. Moving from this discussion to an examination of Jung's reflections on Buddhism, taken directly from Jung's writings, conclusions are drawn regarding Jung's hermeneutic method of approaching the Buddhist canon.

DOURLEY, John P. 'The Jung-White dialogue and why it couldn't work and won't go away.' Journal of Analytical Psychology 52 (2007): 275-95.

White's Thomism and its Aristotelian foundation were at the heart of his differences with Jung over the fifteen years of their dialogue. The paper examines the precedents and consequences of the imposition of Thomism on the Catholic Church in 1879 in order to clarify the presuppositions White carried into his dialogue with Jung. It then selects two of Jung's major letters to White to show how their dialogue influenced Jung's later substantial work, especially his Answer to Job. The dialogue with White contributed to foundational elements in the older Jung's development of his myth which simply outstripped White's theological imagination and continues to challenge the worlds of contemporary monotheistic orthodoxy in all their variants.

GRAF-NOLD, Angela. 'C. G. Jung's position at the Eidgenössische Technische Hochschule Zürich (ETH Zürich) - the Swiss Federal Institute of Technology Zurich.' Jung History 2, 2 (2007): 12-5.

Jeromson, Barry. 'The sources of Systema Munditotius: Mandalas, myths and a misinterpretation.' Jung History 2, 2 (Fall 2007): 20-6.

MAILlARD, Christine. 'Structures triadiques et figures du tiers dans la pensée de Carl Gustav Jung.' In DAHAN-GAIDA, Laurence (ed.). Le Tiers dans tous ses états. Besançon: Presses Universitaires de Franche-Comté, 2007: 17-29.

\section{Segal, Robert A. 'Jung and Lévy-Bruhl.' Journal of Analytical Psychology 52, 5} (November 2007): 635-58.

For his knowledge of 'primitive' peoples, C. G. Jung relied on the work of Lucien Lévy-Bruhl (1857-1939), a French philosopher who in mid-career became an armchair anthropologist. In a series of books from 1910 on, LévyBruhl asserted that 'primitive' peoples had been misunderstood by modern Westerners. Rather than thinking like moderns, just less rigorously, 'primitives' harbour a mentality of their own. 'Primitive' thinking is both 'mystical' and 'prelogical'. By 'mystical', Lévy-Bruhl meant that 'primitive' peoples experience the world as identical with themselves. Their relationship to the world, including to fellow human beings, is that of participation mystique. By 'prelogical', Lévy-Bruhl meant that 'primitive' thinking is indifferent to contradictions. 'Primitive' peoples deem all things identical with one another yet somehow still distinct. A human is at once a tree and still a human being. Jung accepted unquestioningly Lévy-Bruhl's depiction of the 'primitive' mind, even when Jung, unlike Lévy-Bruhl, journeyed to the field to see 'primitive' peoples firsthand. But Jung altered Lévy-Bruhl's conception of 'primitive' mentality in three key ways. First, he psychologized it. Whereas for Lévy-Bruhl 'primitive' thinking is to be explained sociologically, for Jung it is to be explained psychologically: 'primitive' peoples think as they do because they live in a state of unconsciousness. Second, Jung universalized 'primitive' mentality. Whereas for Lévy-Bruhl 'primitive' thinking is ever more being replaced by modern thinking, for Jung 'primitive' thinking is the initial psychological state of all human beings. Third, Jung appreciated 'primitive' thinking. Whereas for Lévy-Bruhl 'primitive' thinking is false, for Jung it is true-once it is recognized as an expression not of how the world but of how the unconscious works. I consider, along with the criticisms of Lévy-Bruhl's conception of 'primitive' thinking by his fellow anthropologists and philosophers, whether Jung in fact grasped all that Lévy-Bruhl meant by 'primitive' thinking.

SHAmDASAni, Sonu. 'Who is Jung's Philemon? An unpublished letter to Alice Raphael.' Jung History 2, 2 (Fall 2007): 5-7. 
STEIN, Murray. 'Of texts and contexts: reflections upon the publication of The JungWhite Letters.' Journal of Analytical Psychology 52 (2007): 297-319.

In addition to his many other personae, Jung was a writer and an author, which means a creator, whose written works underlie and authorize a field of thought and clinical work, i.e., analytical psychology. Not widely recognized is that many of his authored texts were stimulated by important and intense personal relationships. Freud and Victor White loom large, the first standing behind major early analytical texts like Wandlungen und Symbole der Libido and Psychological Types, the second behind later texts on culture, religion, and Christian theology. The publication of The Jung-White Letters reveals the significance of his relationship with Victor White for the authoring of Answer to Job.

TAYLOR, Eugene. 'Jung on Swedenborg, Redivivus.' Jung History 2, 2 (Fall 2007): 27-31.

WHAN, Michael. 'Figures of time and meaning in Jung's interpretation of dreams.' Jung History 2, 2 (Fall 2007): 2-5.

ZIPSER, Barbara. 'Jung's hermaphrodites and the absence of Ovid.' Jung History 2, 2 (Fall 2007): 12-5.

\section{8}

$\underline{B o o k s}$

Bishop, Paul. Analytical Psychology and German Classical Aesthetics: Goethe, Schiller and Jung. London: Routledge, 2008.

DOURLEY, John. Paul Tillich, Carl Jung and the Recovery of Religion. London, New York: Routledge, 2008.

Lawson, Thomas. Carl Jung. Darwin of the Mind. London: Karnac, 2008.

\section{Articles and book chapters}

BURLESON, Blake. 'Jung in Africa: the historical record.' Journal of Analytical Psychology 53 (May 2008): 209-23.

Blake Burleson's ninety-minute presentation was part one of 'A Passage to Africa' moderated by John Beebe. Eight individual filmed sequences from home movies taken by Helton Godwin Baynes during Jung's 1925 expedition to East Africa were shown. In addition to placing these clips in their historical, geographic, and cultural context, Burleson introduced the following cultural complexes revealed in the film and in travelling companion Ruth Bailey's commentary on the film: romantic primitivism, 'going black', self-conscious élite, 'furor Africanus', the 'black man's burden', racial inferiority, and the 'curse of Ham'.

BRUNDKE, Astrid. 'C. G. Jung und Friedrich Seifert. Zum Einfluss der analytischen Psychologie auf die deutsche Psychotherapie während der NS-Zeit.' In BAURIEDL Thea, and Astrid BRUndKe (ed.). Psychoanalyse in München: eine Spurensuche. Gießen: Psychosozial-Verlag, 2008: 343-6o. 
PIETIKÄInEN, Petteri. 'C. G. Jung's Psychoutopia and the “German Revolution” of 1933', in Junginger, Horst (ed.). The Study of Religion under the Impact of Fascism, Leiden, Boston: Brill, 2008: 591-611.

In this chapter, the author tries to practice what he preaches and uncovers some of Carl Gustav Jung's beliefs and intentions concerning Nazi Germany. Following Skinner and Wittgenstein, the author endorses the statement that 'words are also deeds' - we are always doing something as well as saying something. With regard to thinkers like Jung, who made sweeping statements about Hitler's Germany and the Jews, this argument about the performativity of texts is incontestable. The chapter briefly discusses a mentality and a worldview which clarifies the connection between Jung's beliefs (concerning the psychic functioning of people) and intentions (with regard to politics and culture). If antitemporalism was a 'mentality' that governed the way Jung approached issues he was interested in, German antipositivist holism was a worldview that shaped the way in which many scientists, physicians and scholars, Jung among them, looked at reality.

SHAMDASANI, Sonu. “The boundless expanse”: Jung's reflections on life and death.' Quadrant: The Journal of the C. G. Jung Foundation for Analytical Psychology 38 (2008): 9-32.

This article is a text version of the Inaugural Philip Zabriskie Memorial Lecture at the Jungian Psychoanalytic Association, New York, November 2, 2007, which was delivered extemporised. ... 'Boundless expanse' is an expression that Jung used to characterize the state after death in "Archetypes of the collective unconscious" CW 9, 1, § 45 .

Wendy, Swan. 'C. G. Jung's Psychotherapeutic Technique of Active Imagination in Historical Context." Psychoanalysis and History 10, 2 (2008): 185-204.

This essay in the history of psychoanalysis investigates C.G. Jung's psychotherapeutic technique of active imagination, a state of consciousness in which images from the unconscious are brought to conscious awareness and are expressed artistically in a number of different forms such as writing, painting, sculpting, or dance. This essay outlines the state of psychotherapeutics at the turn of the twentieth century and situates Jung's practice of active imagination in other researches concurrently being undertaken in France, England, Switzerland, Germany, and the United States.

\section{9}

$\underline{B o o k s}$

CHONÉ, Aurélie. Rudolf Steiner, Carl Gustav Jung, Hermann Hesse, passeurs entre Orient et Occident. Intégration et transformation des savoirs sur l'Orient dans l'espace germanophone (1890-1940). Strasbourg: Presses Universitaires de Strasbourg, 2009.

Jung, Andreas, Regula Michel, Arthur RüEgG, Judith Roher, and Daniel Ganz. Haus C.G. Jung: Entstehung und Erneuerung des Wohnhauses von Emma und Carl Gustav Jung-Rauschenbach, Zürich: Kommissionsverlag FO Print \& Media, 2009.

English translation: The House of C. G. Jung: The History and Restoration of the Residence of Emma and Carl Gustav Jung-Rauschenbach. Wilmette: Chiron Publications, 2009.

LEWIN, Nicholas Adam. Jung on War, Politics and Nazi Germany. Exploring the Theory of Archetypes and the Collective Unconscious. London: Karnac Books, 2009.

Miller, Arthur I. Deciphering the Cosmic Number: The Strange Friendship of Wolfgang Pauli and Carl Jung. New York, London: W. W. Norton \& Company, 2009.

Stephenson, Craig E. Possession: Jung's Comparative Anatomy of the Psyche. London, New York: Routledge, 2009. 
WILHelm, Hans Rudolf. Carl Gustav Jungs Vermächtnis : die Geburtsurkunde zur analytischen Psychologie aus dem Jahre 1897. Hürtgenwald : Pressler, 2009.

\title{
Articles and introductions
}

\begin{abstract}
ADDISON, Ann. 'Jung, vitalism and "the psychoid": an historical reconstruction.' Journal of Analytical Psychology 55, 1 (February 2009): 123-42.

This paper traces the history of Jung's ideas concerning the psychoid unconscious, from their origins in the work of the vitalist, Hans Driesch, and his concept of Das Psychoid, through the subsequent work of Eugen Bleuler, Director of the Burghölzli Asylum, and his concept of Die Psychoide, to the publication of Jung's paper On the Nature of the Psyche in 1947. This involves a review of Jung's early work and of his meeting with Freud, when apparently the two men discussed calling the unconscious 'psychoid', as well as a review of Jung's more mature ideas concerning a psychoid unconscious. I propose to argue that even at the time of their meeting, Jung had already formulated an epistemological approach that was significantly different from that of Freud and that clearly foreshadowed his later ideas as set out in On the Nature of the Psyche.
\end{abstract}

BISHOP, Paul. 'Jung looking at the stars: chaos, cosmos and archetype.' International Journal of Jungian Studies 1, 1 (March 2009): 12-24.

Taking as its starting-point an aphorism in The gay science, this paper examines Nietzsche's distinction between the (chaotic) 'total character of the world' and the (cosmic) 'astral order in which we live'. It relates this distinction, not only to Nietzsche's earlier claim in The birth of tragedy that 'it is only as an aesthetic phenomenon that existence and the world are eternally justified', but also, via Goethe's Wilhelm Meister, to Jung's concept of archetypal structures. Finally, it examines the case of one of Jung's patients, a young labourer suffering from schizophrenia; Jung's interest in Hölderlin; and his discussion of the Stoic concept of heimarmene.

\section{CLendenen, Avis. 'Encounter with the unconscious.' Jung Journal: Culture E Psyche 5, 3} (2009): 39-56.

Twelfth-century Hildegard of Bingen's lush interior life foreshadowed twentieth-century Jungian insight into the rich contents of the unconscious in human personality. "Encounter with the Unconscious: Hildegard in Jung" provides an overview of the seven references in Jung's Collected Works to Hildegard of Bingen, who, in Jung's own words, was "an outstanding personality quite apart from her mysticism" (CW 13, §42). Murray Stein contends that Jung was guided in his writings "by an unseen hand, a largely unconscious spiritus rector [guiding spirit]." Eight centuries earlier Hildegard was motivated by the same impulse and guided by a similar spirit-the umbra viventis lucis-the Living Light within her soul. This article offers an interpretation of Jung's interest in a woman from another era upon whom he could rely while pioneering the rich, colorful, and symbolic spiritual terrain of the unconscious. Both medieval Benedictine Abbess Hildegard and modern depth psychologist Jung sought to heal a Christianity in crisis. Each experienced a visionary life that gripped them from within with images and ideas that have outlived them. Jung found in twelfth-century Hildegard a scientific theorist supportive of his findings on the life of the unconscious in human personality, as well as a mystic able to experience the visionary life while retaining psychic integrity- or, expressed within his conceptual framework, as a woman who achieved individuation, an evolved individuality.

\section{Collins, Jo. “'Shadow Selves” Jung, Africa and the psyche.' Interventions 11, 1 (2009):} 69-8o.

Swiss psychologist, and erstwhile discipline of Freud, Carl Gustav Jung was excommunicated from the psychoanalytic movement in 1913 for delving into the occult and for challenging Freud's sexually based notion of the libido. He went on to develop his own psychological method - analytical psychology - in which 'Africa' was decisive. For Jung, Africa and its inhabitants represented the 'primitive', the unconscious, 'the other', which then enabled him to conjecture about the nature of the European psyche. Jung's visits to Tunisia and Algeria in 1920, and Kenya and Uganda in 1926, were, in effect, fact finding missions to enable him to consolidate his theories. These theories were premised on a polarization between the European and 'the other', where the dualisms of 'civilized' and 'primitive' societies were mapped onto the conscious and unconscious, respectively. Nevertheless, his autobiographical ruminations in Memories, Dreams, Reflections (published just after Jung's death in 1961) and his theoretical writings show that he found these African environments to be problematic, troubling and difficult to comprehend: the African surroundings are depicted as unnerving, disease-ridden, or swarming with hidden threats and would not sit comfortably with his theoretical postulates. This essay not only considers the shortcomings of Jung's realizations of Africa, but also questions the ramifications of such notions within Jungian thinking, when taking into account the imbrication of Jung's theories in contemporary imperial discourses. 
FALZEDER, Ernst. 'Paul Mellon (1907-1999), Mäzen der Jung- und der Freud-Forschung'. Luzifer-Amor 44 (2009): 165-66.

FAlZeDER, Ernst. 'Psychoanalyse und Psychiatrie 1908-1913. Freud, Bleuler, Jung und die geplante Eroberung der Psychiatrie'. Gemeindenahe Psychiatrie 30, 101, (2009): 7-25.

GARDNER, Leslie. 'Pathos in Jung's Answer to Job: anger as a mode of cognition and as a faculty of understanding.' International Journal of Jungian Studies 1, 1 (March 2009): 33-49.

Jung applies the classical rhetorical strategy of pathos in his long essay to drive his controversial arguments. In doing so, his innovative ideas about the faculty of emotion as an instrument of cognition are revealed. After a discussion of the reception of this work and Jung's intentions, I will follow with a brief history of emotion in persuasion. First I will outline how passion as a credible ploy of argumentation developed, shifting from pre-Socratic to Aristotelian concepts. I make reference to the traditional presence of anger in religious persuasion and its appearance in the Old Testament. Using rhetorical analysis, I trace Jung's specific and justifiable use of passional techniques in Answer to Job to make his case.

Herrmann, Steven B. 'Colloquy with the inner Friend Jung's religious feeling for Islam.' Jung Journal: Culture E Psyche 3, 4 (2009): 123-32.

This paper considers Marie-Louise von Franz's use of the words love, differentiated feeling, eros, and civilization in her lecture 'C. G. Jung's Rehabilitation of the Feeling Function in Our Civilization.' and explores how we might begin to acknowledge the reality of the Self, when the world-embracing spirit of God insists upon an awareness of the shadow and evil. What did Jung's grappling with the God-function-feeling-have to do with Islam? Jung's Auseinandersetzung with the "God-complex" (Jung CW 6) was pivotal to his arrival at a theory of the Self as a way of transcending doctrinal disputes in all three monotheisms. Religious splitting within Islam is a reality that Jung wrestled with in an important dream during his travels to the Muslim city of Tunis, on the northern tip of Africa in 1920; he continued to grapple with the problem of religious dualism in Persian Zoroastrianism, Mithraicism, Manichaeism, and Islam between 1934 and 1939. By the time his seminars on Nietzsche's Zarathustra ended on the eve of WW II, he had zeroed in on the pivotal role that the figure of Khidr plays in Islamic mysticism. Jung cites the 'colloquy with the friend of the soul,' Allah, or the Self, as a paradigm for a dialogical method of active imagination, which, if used with right feeling, and in an embodied way, can be employed as a technique for transcending splits within the historical Godimage. He exemplifies this technique in Answer to Job.

\section{Monahan, Paula A. 'C. G. Jung: Freud's heir or Janet's? The influence upon Jung of} Janet's dissociationism.' International Journal of Jungian Studies 1, 1 (March 2009): $33-49$.

'What Jung called 'complex' was originally nothing but the equivalent of Janet's "subconscious fixed idea", says Henri Ellenberger in his magisterial book The Discovery of the Unconscious, the work which first resurrected Pierre Janet's memory after decades of virtual oblivion. My purpose in this article will be to discuss the influence of Janet, with whom Jung studied in Paris in the winter semester of 1902-1903, upon the overall development of Jung's thought, and in particular upon his complex theory. Whilst the groundbreaking work of John Haule has gone some way to highlighting the importance of Janet's influence upon Jung, I hope to demonstrate that a further analysis of Janet's thought in the Jungian corpus gives promise of yielding many more insights into Jung's own thought, insights which might also contribute to the burgeoning research into dissociative disorders that has been taking place in recent decades.

\section{MYERS, Steve. 'The cryptomnesic origins of Jung's dream of the multi-storeyed house.' Journal of Analytical Psychology 54 (2009): 513-31.}

Jung first recounted his dream of the multi-storeyed house in the 1925 seminars to illustrate the concept of the collective unconscious and explain the influence of phylogeny on his split with Freud. However, his telling the story of the dream belies a cryptomnesic influence of the early writings of psychoanalysis because Josef Breuer used a similar image to illustrate the structure of the psyche which Édouard Claparède associated with a phylogenetic inheritance. When telling the story of the dream, Jung misrepresented Freud's position, creating the impression of there being a bigger difference between their theories than was actually the case, and giving the dream a fictional significance for the breakdown of their relationship. In fact, Jung followed Freud into the fields of mythology and phylogenetics, and their split was due primarily to their different attitudes towards sexuality rather than phylogeny. The dream image has therefore led to a misunderstanding of Freudian theory when viewed from within a Jungian perspective. Freud believed there was a phylogenetic layer in the psyche, though he held a different view to Jung on its nature and importance. 


\section{RuTTE, Joseph W. 'The White-Jung friendship: the untold story.' Psychological}

Perspectives 52 (2009): 292-314.

For decades Jung searched in vain for a theologian with whom he could deeply and openly converse about his new vision of Christianity. Only very late in his life did he find and form a deep friendship with Victor White, a Dominican theology professor, whose own psychic life was saved by Jung's teachings. Jung saw White as the first theologian he had met who truly understood his psychology. Jung wanted to use White's expertise in Catholic theology in his pioneering efforts to transform Christianity, through his psychology, into a living, breathing, vital faith in the divine. For his part, White wanted to resuscitate Thomistic theology by infusing its dry, cerebral character with the emotional vitality of the original Thomas Aquinas by using his newly discovered Jungian teachings combined with some of the original teachings of Aquinas. In the process of their work together, Jung and White became close, trusting friends. However, White was pushed beyond the limits of his psychological resources by political events within his order, whose superiors destroyed his career as a theologian and sent him into exile. In his scathing review of Answer to Job, White displaced his anger/rage onto Jung instead of the appropriate objects. This attack wounded their friendship deeply, and it was only toward the end of their lives that a partial reconciliation was possible. And yet, Jung's friendship with White was perhaps the closest and most trusting relationship he had with a man during his lifetime. Finally, I suggest that White's mission in this life was to resuscitate Thomism rather than help Jung achieve his purposes, and that White achieved his mission.

Shamdasani, Sonu. 'Liber Novus: The “Red Book” of C. G. Jung.' JunG, C. G. Liber Novus: The Red Book. New York, London: W. W. Norton \& Company, Philemon Series, 2009: 193-221.

German translation: 'Liber Novus: das “Rote Buch” C. G. Jung.' In JuNG, C. G. Liber Novus: Das Rote Buch. Ostfildern: Patmos Verlag, 2009: 195-223, translated by C. Hermes.

Italien translation: 'Liber Novus: il "Libro rosso" di C. G. Jung.' In JUNG, C. G. Il Libro rosso: Liber Novus, Bollati Boringhieri, 2010: 193-221, translated by G. Schiavoni, M. A. Massimello, and G. Sorge.

French translation: 'Liber Novus: le "Livre Rouge” de C. G. Jung.' In JUNG, C. G. Liber Novus. Le Livre Rouge. Paris: La Compagnie du Livre Rouge, L’Iconoclaste, 2011: 193-226, translated by B. Dunner, J. Vieljeux and P. Crouzet.

\section{SchoENL, William. 'The World War II attacks on Jung: Eleanor Bertine's and Esther} Harding's perspectives.' Quadrant: The Journal of the C. G. Jung Foundation 39, 1 (2009): 17-27.

\section{SchOENL, William. “BBC broadcasters” unpublished views on Jung: Priestley and} Freeman.' International Journal of Jungian Studies 1, 2 (September 2009): 158-62.

This article shows the unpublished views of J. B. Priestley and John Freeman, two significant BBC broadcasters on Jung. Priestley puzzled over individuation in Jung, but his most striking comment was that H. G. Baynes' death in 1943 had been an enormous loss to Jungians in Britain. Freeman strikingly commented on MarieLouise von Franz as the most important person in Jung's life after Emma Jung's death, on Jung's immediate entourage regarding him as a sort of demi-God in his last years, and on India perhaps being more than he could sustain. Freeman acted as co-ordinating editor of Jung's final book, Man and his symbols.

Wheelwright, Betty Coon. 'The Road to Zürich. Jane and Jo Wheelwright, 1929-1932.' Jung Journal: Culture E Psyche 5, 3 (2009): 10-38.

This is the story of how two first-generation Jungian analysts encountered C. G. Jung and made the decision to become Jungian analysts. Their story is embedded in and influenced by family history and circumstances, and it takes place during the years between the two World Wars of the twentieth century. In 1931, Joseph Balch Wheelwright and Jane Hollister Wheelwright were traveling around the world on an extended honeymoon, which was ended by rising political unrest while they were in China. Jane Wheelwright traveled from Beijing to California with her infant daughter, Lynda, and Joseph Wheelwright traveled north to Harbin, where he caught the Trans-Siberian Railway to Moscow. While visiting her family in California, family members asked Jane Wheelwright to accompany her aunt and uncle, Laura Steffens Suggett and Allen Holman Suggett, to a consultation with C. G. Jung in Zürich, Switzerland. Joseph Wheelwright joined the family group in Marseilles, and the Suggetts and Wheelwrights arrived in Zürich in early March 1932. Laura Suggett, who had suffered a severe mental breakdown, had several interviews with C. G. Jung, and the Wheelwrights met with Jung several times to discuss Jung's opinion of Laura's mental state. Joseph Wheelwright also met individually with Jung to discuss his marital relationship. Meeting Jung was a turning point in the Wheelwrights' lives. Joseph Wheelwright decided to embark on the long course of study that was necessary for him to become a physician and Jungian analyst, and for the following six years, both of the Wheelwrights returned many times to Zürich for analysis or to attend Jung's lectures. 
VAN DEN BERGH, Jean-Luc. Les rêves et les visions de Carl Gustav Jung. Paris: L'Harmattan, 2010.

Quaglino, Gian Pero. Nel giardino di Jung. Milano: R. Cortina, 2010.

NANTE, Bernardo. El Libro Rojo de Jung. Buenos Aires: Siruela, 2010.

SHERrY, Jay. Carl Gustav Jung. Avant-Garde Conservative. New York: Palgrave MacMillan, 2010.

SpILlmanN, Brigitte, and Robert StRUBel. C. G. Jung: Zerrissen zwischen Mythos und Wirklichkeit. Über die Folgen persönlicher und kollektiver Spaltung im tiefenpsychologischen Erbe. Gießen: Psychosozial-Verlag, 2010.

\section{Articles}

DoHe, Carrie B. 'Wotan and the 'archetypal Ergriffenheit': Mystical union, national spiritual rebirth and culture-creating capacity in C. G. Jung's "Wotan” essay.' History of European Ideas 37, 3 (2010): 344-56.

This article analyses the 1936 "Wotan" essay by Swiss psychologist Carl Gustav Jung in light of one of its reigning motifs, Ergriffenheit. First, this term is examined within the works of Protestant theologian Rudolf Otto and Indologist Jakob Wilhelm Hauer, who used it to describe what they claimed to be the original religious experience, a state of being deeply stirred or even seized by the 'the holy' or by 'the ultimate reality.' The article then examines antecedents in Jung's theory of states of psychic seizure, in which two halves of the psyche come into conflict, the resolution of which leads to an increased capacity to create the arts of culture. The analysis then moves to the 'Wotan' essay itself, where Jung brings together his own theory of psychic seizure with the theory of the original religious experience as proposed by the above-named scholars of religion in order to suggest that, under National Socialism, the Germans were in the midst of a collective confrontation with their own inner divinity, which should lead to a national spiritual rebirth. The article then investigates the works of several of the men Jung mentions in the essay, as well as his use of ancient Germanic mythology, to support his claim. Through his portrait of the Germanic archetype Wotan, Jung psychologizes and thereby essentializes the Romantic image of the Germans as "a people of poets and philosophers" as well as that of a Nietzschean 'master-race.' In conclusion, the article argues that, at least in 1936, Jung's attitude towards Hitler and National Socialism was much more favorable than has previously been recognized.

Giegerich, Wolfgang. 'Liber Novus, that is, The New Bible. A first analysis of C. G. Jung's Red Book.' Spring: A Journal of Archetype and Culture 83 (2010): 361-411.

GRAF-NOLD, Angela. 'Jung's ETH lectures on "Modern Psychology" 1933-44: Jung's contribution to the Social and Political Culture.' XVIIIth Congress of the International Association for Analytical Psychology: Facing Mulitplicity: Psyche, Nature, Culture. Einsiedeln: Daimon Verlag, 2010: 532-38.

Quaglino, Gian Piero, and Augusto Romano, Riccardo Bernardini, 'Opicinus de Canistris: some notes from Jung's unpublished Eranos Seminar on the medieval Codex Palatinus Latinus 1993." Journal of Analytical Psychology 55 (2010): 398422, translated by V. Marsicano. 
LiNDNER, Michael, “Ein tiefstes Erlebnis”. C. G. Jungs Lektüre von Nietzsches Also sprach Zarathustra anhand seiner Seminare von 1934-39.' In LESMEISTER, Roman and Elke METZNER (eds.). Nietzsche und die Tiefenpsychologie. Freiburg, Munich: Verlag Karl Alber, 2010: 107-20.

RowLAND, Susan. 'Jung's cultural writing and Modern man in search of a soul (1933): spiral essays and performing symbols.' International Journal of Jungian Studies 2, 1 (March 2010): 21-31.

C. G. Jung published in English, in 1933, Modern man in search of a soul. This book, I argue, is a response to related problems of psychologists writing cultural analysis, and to the difficulty of writing down the psyche itself. Given that Jung's most foundational belief is of the importance of the unconscious as source of creativity and of mystery, writing itself has to make room for 'other' voices and 'other' ways of arguing, in addition to rational abstract concepts, in order to fulfil Jung's vision. Symbol, myth, narrative and, crucially, spiral form embody and enact the psyche in culture.

VAN SchoOnHETEN, Anna Bentinck. 'Salzburg 1908. Karl Abraham in der Klemme zwischen Freud und Jung.' Luzifer-Amor. Zeitschrift zur Geschichte der Psychoanalyse 23 (2010): 1-23.

The first psychoanalytic congress in Salzburg has often been described as a great success with one blemish: a conflict between Jung and Abraham, mainly caused by the rivalry in Abraham's behaviour. A new study of the material, and taking Abraham's perspective, provides a different view. Abraham, still a beginner in psychoanalysis, got in the way of Freud and Jung who at that time had a deep theoretical disagreement. In the end they both blamed Abraham.

SEAGAL, Robert A. 'Jung as psychologist of religion and Jung as philosopher of religion.' Journal of Analytical Psychology 55, 3 (June 2010): 361-84.

Is it possible to be both a psychologist and a philosopher? Is it possible for a psychologist, or more generally a social scientist, to use social scientific findings to make philosophical claims? Specifically, is it possible for a social scientist to use social scientific findings to determine the existence of God? Did Jung profess to be only a psychologist or also a philosopher? If he professed to be both, did he enlist his psychological findings to make philosophical claims? Specifically, did he enlist his psychological findings to determine the existence of God?

Shamdasani, Sonu and John BeEbe. 'Jung becomes Jung: A dialogue on Liber Novus (The Red Book).' Psychological Perspectives 53 (2010): 410-36.

C. G. Jung's Liber Novus, his title for the long privately held work known familiarly as The Red Book, forms the subject of a dialogue between its editor, Jung historian Sonu Shamdasani, and Jungian analyst John Beebe. Conducted in the third month after the work's first publication in facsimile and English translation, their conversation touches on the book's importance within Jungian studies and its unexpected popularity with a wider audience as Jung's first best-seller. They discuss how a close reading of this book's text can help to dispel misconceptions about Jung and about the empirical ground of his later psychology. They note that the self-experiment with individual vision that Liber Novus records, without recourse to psychological jargon or preconception, reveals Jung's recognition of a need to sacrifice the hero archetype and accept responsibility for what he regarded as his complicity with the egoistic spirit that had shaped the lead-up to World War I. A sense of duty, driven by what he felt was necessary to reconnect with his soul, gave him the energy to participate actively in the imaginations that emerged through encounters with figures that appeared in his dreams and waking reveries. In a personal variation of medieval theology's imitatio Christi, Jung's "I" was led to make a fantasized descent to Hell and to take up "the lament of the dead." The meanings of the sacrifices involved are explored to reveal their role in helping Jung to realize the nature of human individuation beyond mere ego development. 
BERNARDINI, Riccardo. Jung a Eranos. Il progetto della psicologia complessa. Milano: Franco Angeli, 2011.

LIEBSCHER, Martin. Libido und Wille zur Macht: C. G. Jungs Auseinandersetzung mit Nietzsche. Basel: Schwabe, 2011.

METZNER Elke, and Martin SchIMKUS (eds.). Die Gründung der Internationalen Psychoanalytischen Vereinigung durch Freud und Jung. Gießen: PsychosozialVerlag, 2011.

REGINA, Vincenzo. Freud e Jung: il dibattito epistolare 1906-1913. Napoli: Vox, 2011.

Swan, Wendy K. (éd.), The Memoir of Tina Keller-Jenny. A Lifelong Confrontation with the Psychology of C. G. Jung, New Orleans: Spring Journal Books, 2011.

Tagliagambe, Silvano, and Angelo Malinconico. Pauli e Jung: un confronto su materie e psiche. Milano: R. Cortina, 2011.

VignA, Ferruccio (ed.). La depressione creativa. Dal Libro rosso di Jung alla modernità. Roma: Moretti \& Vitali, 2011.

Articles, introductions and book chapters

AIELLO, Angelo Gabriele. 'Il distacco di Jung da Freud.' Il Minotauro 38, 1 (giugno 2011): 11-13.

BAIER, Karl. 'Das Rote Buch im Kontext Europäischer Spiritualitätsgeschichte.' Recherches germaniques hors série 8 (2011): 13-40.

BERIVI, Sandra. 'L'apporto del sacro allo sviluppo psicologico del femminile nel Libro rosso di C. G. Jung.' Il Minotauro 38, 1 (giugno 2011): 146-65.

Bernardini, Riccardo, Gian Piero Quaglino, and Augusto Romano. 'A visit paid to Jung by Alwine von Keller.' Journal of Analytical Psychology 56, 2 (April 2011): 232-54. In the winter of 1943-1944, Jung had suffered a coronary thrombosis which almost cost him his life. During
his illness, Jung experienced a series of visions, described in his Memories, Dreams, Reflections, which were also to
influence significantly the development of his theoretical thinking. On 27 (th) September 1944, Alwine von Keller (1878-
1965) paid a visit to Jung, while he was still convalescing, in Zurich and documented her meeting with him in a series of
notes, recently discovered, which testify to the fact that, at the time of their meeting, Jung was engaged in writing the
'Salt' chapter of Mysterium coniunctionis and investigating the alchemistic symbolism of the 'sea'. This theme seems to
testify to a continuity of interests on Jung's part with the seminar he held at Eranos the previous year on the
cartographic art of Opicinus de Canistris (1296-c.1352). With its addition of many unpublished details, Alwine von
Keller's notes supplement the report which Jung made of his visions experienced during his sickness in MDR. In
particular, these attest to the fact that Jung had attributed the terrible experience which he had endured to the problem 
of the conjunctio, which was confronting him from the theoretical point of view in his writing of Mysterium coniunctionis.

Bishop, Paul. 'Sinn, Unsinn, Widersinn, Wahnsinn, Übersinn. Selbst- und Gottesvorstellungen im Roten Buch von C. G. Jung.' Recherches germaniques hors série 8 (2011): 135-52.

CAmbray, Joseph. 'L'influence d'Ernst Haeckel dans le Livre Rouge de Carl Gustav Jung.' Recherches germaniques hors série 8 (2011): 41-6o.

CAMBray, Joseph. 'Jung, science, and his legacy.' International Journal of Jungian Studies 3, 2 (October 2011): 110-124.

C. G. Jung's choice of a science-based career in medicine is examined beginning with his dreams at age 19. His first Zofinga lecture gives perspective on his views on the science of the time and helps clarify aspects of his education. The influence of Ernst Haeckel, the German scientist and artist, are drawn out in the context of images from Jung's Red book. After stopping work on the Red book, Jung again embraced aspects of science but these were now more directly put to use to support his own theoretical frame, which could be read as a visionary science or a science of the visionary. This has led to a legacy of ambivalence regarding science, but in this article some areas of mutual interest with contemporary neuroscience are noted.

Conrad Lammers, Ann. 'Introduction.' In The Jung-Kirsch Letters. The Correspondence ofC. G. Jung and James Kirsch. London, New York: Routledge, 2011: xxvii-xxxvii. German translation: C. G. Jung und James Kirsch. Die Briefe 1928-1961, Ostfildern, Patmos Verlag, Edition C. G. Jung, 2013: xxvii-xxxvii.

FABJ, Luca Valerio. 'Il Liber novus come archetipo del 'processo di individuazione' dell'opus alchemico.' Il Minotauro 38, 1 (June 2011): 14-43.

FABJ, Luca Valerio. 'Jung e la scienza del sacro.' Il Minotauro 38, 1, (June 2011): 44-72.

FABJ, Luca Valerio. 'L'immaginazione attiva: concetti generali teorico/pratici.' Il Minotauro 38, 1 (June 2011): 73-103.

FALZEDER, Ernst. 'Freud und Jung, Freudianer und Jungianer'. Zeitschrift des SAP 19, (July 2011): 5-31.

This article tries to throw new light on the Freud/Jung relationship. First, it studies the nature of the fundamental differences between the two theories. Second, it raises the question of what, and how much, each of them took over from the other, with the result that Freud let himself be more inspired by Jung than vice versa. Third, the stimulating effect of their conflicts and of their break on the respective development of their theories is underlined. Finally, some light is thrown on the differences between the respective developments of the Freudian and Jungian organizations.

43 .

English translation: 'Freud and Jung, Freudians and Jungians.' Jung Journal: Culture E Psyche 6, 3 (2012): 24-

French translation: 'Freud et Jung - Freudiens et Jungiens.' Psychothérapies 34, 1 (2014): 9-22.

FALZEDER, Ernst. 'Freud und Jung'. Luzifer-Amor 24, 48 (2011): 156-173.

FISCHER, Thomas. 'The alchemical rare book collection of C. G. Jung.' International Journal of Jungian Studies 3, 2 (October 2011): 169-80.

Following the publication of The Red Book, the Foundation of the Works of C. G. Jung is currently working on the preservation and accessibility of Jung's private library for further research purposes. In 2010, in collaboration with the library of ETH Zurich, the Foundation started a digitizing project with the aim to publish (on http://www.erara.ch) Jung's valuable rare book collection on alchemy, magic and the Kabbalah. This article provides background information on how and why Jung assembled his collection of rare books in the 1930s, and what the digitizing project offers to Jungian scholars. 
GAILlARD, Christian. 'À propos de quelques illustrations du Livre Rouge. D'Izdubar à Job.' Recherches germaniques hors série 8 (2011): 61-88.

GAILlARD, Christian. 'Jung 1928, entre cour et jardin, la perspective (introduction à C. G. Jung, “La psychologie de l'homme moderne” (1928).' Cahiers jungiens de psychanalyse 134 (septembre 2011): 159-64.

GrASSI, Antonio. 'Il Libro rosso di Jung: un grande interrogativo sul rapporto tra psicologia analitica e trascendenza.' Il Minotauro 38, 1 (giugno 2011): 108-45.

HARMS, Donald. 'The Geometry of C. G. Jung's Systema Munditotius Mandala.' Jung Journal: Culture E Psyche 5, 3 (2011): 145-59.

I have found the geometry of the mandala exists deep in the psyche as it appears in the Systema Munditotius mandala of C. G. Jung. In this article, I demonstrate the geometry of proportion, the Divine Proportion, the Golden Section, and the Extreme and Mean Ratio, which I have applied to Jung's Systema Munditotius mandala published in The Red Book. I analyze Jung's first mandala in its religious context and the philosophy of Immanuel Kant, an important influence on Jung's psychology.

HoERnI, Ulrich. 'The Foundation of the Works of C. G. Jung.' Spring: A Journal of Archetype and Culture 86 (Fall 2011): 183-92.

LAVALLEE, Jeanne. 'The Impress of Heinrich Zimmer's Teachings on C. G. Jung's Profession.' Quadrant: The Journal of the C. G. Jung Foundation XXXXI, 2 (Summer 2011): 25-43.

The influence of C. G. Jung's work on that of Indologist Heinrich Robert Zimmer (1890-1943) is well known to the English speaking world, but how important Zimmer's work was for Jung has, so far, not been highlighted. Zimmer's groundbreaking book on the function of mandalas, entitled Kunstform und Yoga im indischen Kultbild (Artistic Form and Yoga in the Sacred Images of India), published in 1926, was an important step along the way of Jung's own understanding of how the mandala was used in the East. The two men finally made each others' acquaintance in Zürich, Switzerland, on the occasion of a series of lectures on Kundalini Yoga at Jung's Analytical Psychology Club. Zimmer, a Sanskrit Scholar working as a Professor of Indology at the Ruprecht Karls Universität in Heidelberg at the time, lectured 'On the Various Forms of Yoga in the Indian Tradition.' Upon this first meeting, Zimmer and Jung began a professional friendship that would last until Zimmer's early death in 1943. This article traces the indirect collaboration of these two scholars-using as yet unpublished and untranslated letters that passed between them in the 1930s and '4os-with an emphasis on the importance of Zimmer's scholarship for the development of Jung's theories of the collective unconscious and archetypes.

LIARD, Véronique. 'Au commencement n'était pas le verbe. De l'importance de l'image dans le Livre Rouge.’ Recherches germaniques hors série 8 (2011): 89-98.

MAILlARD, Christine. 'Le Livre Rouge de Carl Gustav Jung, document autobiographique, document culturel.' Recherches germaniques hors série 8 (2011): 1-12.

MAILlARD, Christine. 'La pensée de Carl Gustav Jung et les courants néo-gnostiques de la première moitié du XXe siècle.' Recherches germaniques hors série 8 (2011): 99-116.

MAILlARD, Christine. 'Le Livre Rouge de Carl Gustav Jung dans le context de la crise de la connaissance et des valeurs des années 1910-1930.' Recherches germaniques hors série 8 (2011): 153-68. 
MAILlaRD, Christine. “La voie de l'à-venir”. Du discours prophétique dans le Livre Rouge de C. G. Jung.' Cahiers jungiens de psychanalyse 134 (septembre 2011): 11931.

In examining the importance in C.G. Jung's Red Book of the notion of "be-coming" (das Kommende) and of the representations associated to it - such as "the way of what is to come" (des Weg des Kommenden) and "the God yet to come" (der kommende Gott) - this article centers on the prophetic tone of the discourse in these texts, and examines what might be at stake for a Jungian conception of postchristianity and what that implies regarding the concept of a "symbolic life" and for the ideas of individuation and of the Self.

PuscedDU, Maria. 'Lo psicoide.' Il Minotauro 38, 1 (giugno 2011): 166-72.

\section{SCHWEIZER, Andreas. 'The Son of the Earth in C. G. Jung's The Red Book.' Jung Journal:} Culture E Psyche 5, 3 (2011): 78-93.

C. G. Jung's imaginations in The Red Book, the prima materia of his extraordinary creativity, are strongly rooted in cultural traditions, such as Hellenism, Ancient Egypt, the Far East, and others; and, at the same time, they point far ahead in time to future generations. The Red Book is like a flourishing tree : its roots reach far down into the history of the earth, whereas its blossoms already contain the fruits of a time to come. Toward the end of The Red Book, the Son of the Earth resembles more and more Philemon, becoming, as him, a lover of the Soul. At the end of his life, Jung entirely turned into the age-old son of the mother; he, too, became a true lover of the soul!

SERINA, Florent. 'Saisir "le mal de l'âme européenne" (introduction à C. G. Jung, "La psychologie de l'homme moderne” (1928).' Cahiers jungiens de psychanalyse 134 (septembre 2011): 153-57.

SHAMDASANI, Sonu. 'Introduction: Jung, New York, 1912.' In JunG, C. G. Jung contra Freud. The 1912 New York Lectures on the Theory of Psychoanalysis. Princeton: Princeton University Press, 2011: VII-XXI.

SHERRY, Jay. 'Faint voices from Greenwich Village: Jung's impact on the first American avant-garde." Journal of Analytical Psychology 56 (2011): 692-97.

In 1913 Jung made a trip to New York which was to have an important impact on the creation of modern American culture. At the invitation of Beatrice Hinkle, the first Jungian analyst in the country, he spoke to the Liberal Club, a forum for discussing progressive topics. Jung was the leading spokesman for psychoanalysis and his ideas about creative fantasy resonated with popular interest in the ideas of William James and Henri Bergson. This paper will document that visit and the influence that Hinkle had on the young people who had gravitated to Greenwich Village. She promoted Jungian psychology through her analytical practice and her translation of Jung's Wandlungen und Symbole der Libido as Psychology of the Unconscious. Her influence is evident in four key neighbourhood institutions: The Masses, a socialist magazine, The Seven Arts, an avant-garde literary magazine, the Provincetown Players theatre ensemble, and the Heterodoxy Club, America's first feminist group. Her influence is also evident at The New School where several pioneering anthropologists employed the theory of psychological types as a tool for understanding social behaviour. This paper will demonstrate that a cultural moment usually seen through a Freudian lens had, in fact, a remarkably Jungian character.

Solmi, Loris. 'L’interesse di Jung per i fenomeni paranormali.” Il Minotauro 38, 1 (June 2011): 102-07.

SORGE, Giovanni. 'Tra sintomatologia e simbologia. Sull'interpretazione junghiana del nazismo negli anni prebellici (1933-1936).' In WidMANN, Claudio (ed.). Simbolo e sintomo. Quando la psiche prende la via regressiva del sintomo o quella progressiva del simbolo. Roma: Edizioni Scientifiche Magi, 2011: 189-222.

STEIN, Murray. 'Jungian psychology and the spirit of Protestantism.' International Journal of Jungian Studies 3, 2 (2011): 125-43.

German translation: 'Die Psychologie von C. G. Jung und der Geist der Protestantismus.' In SCHWEIZER, Andreas, and Regine SCHWEIZER-VüLLERS (eds.), Baustein. Reflexionen zur Psychology von C. G. Jung, Einsiedeln: Daimon Verlag, 2017: 225-254. 
Drob, Sanford L. Reading the Red Book. An interpretative Guide to C. G. Jung's Liber Novus. New Orleans: Spring Journal, 2012.

LE QuELLEC, Jean-Loïc. Jung et les archétypes. Un mythe contemporain. Paris: Éditions Sciences Humaines, 2012.

LiEBSCHER, Martin. Libido, und Wille zur Macht. C. G. Jungs Auseinandersetzung mit Nietzsche. Basel: Schwabe, 2012.

MAROZZA, Maria Ilena. Jung dopo Jung: saggi critici. Bergamo: Moretti \& Vitali, 2012.

Shamdasani, Sonu. C. G. Jung, A Biography in Books. New York, London: W. W. Norton \& Company, 2012.

Jerotić, Vladeta. Jung entre l'Orient et l'Occident. Lausanne, Paris: L'Âge d'Homme, 2012.

\section{Articles, introductions and reviews}

BernARDini, Riccardo. 'Prospettive di ricerca storica in psicologia analitica.' Tempo d'analisi. Paradigmi junghiani comparati 1 (2012): 151-75.

BERNARDINI, Riccardo. 'Figure della trascendenza nelle culture dell'immanenza: Jung a Eranos.' Hiram 2 (2012): 93-106.

BISHOP, Paul. 'Jung's Red Book and its relation to aspects of German Idealism.' Journal of Analytical Psychology 57 (2012): 335-63.

The late nineteenth century saw a renaissance of interest in the thought of the German Romantic philosopher, F. W. J. Schelling. This paper takes Jung's engagement with Schelling and his awareness of Schellingian ideas and interests (notably, the mysterious Kabeiroi worshipped at Samothrace) as its starting-point. It goes on to argue that a key set of problematics in German Idealism - the relation between freedom and necessity, between science and art, and ultimately between realism and idealism - offers a useful conceptual framework within which to approach Jung's Red Book. For the problem of the ideal is central to this work, which can be read as a journey from eternal ideals to the ideal of eternity. (Although the term 'idealism' has at least four distinct meanings, their distinct senses can be related in different ways to Jung's thinking.) The eloquent embrace of idealism by F. T. Vischer in a novel, Auch Einer, for which Jung had the highest praise, reminds us of the persistence of this tradition, which is still contested and debated in the present day.

Cocks, Geoffrey. 'Psychotherapy in the Third Reich. The politics of a profession in a crisis.' Jung Journal: Culture E Psyche 6, 4 (2012): 25-30.

C. G. Jung's involvement in the professional politics of psychotherapy in Nazi Germany was not a matter only of sympathy for and collaboration with Nazism. Jung's participation in the affairs of professionally endangered and ambitious psychotherapists under the advantageous leadership of a relative of the powerful Hermann Göring was both significant and limited in time and space. While Jungians found a place at the German Institute for Psychological Research and Psychotherapy in Berlin between 1936 and 1945, psychoanalysts and other psychotherapists - purged of practitioners who were Jewish-advanced their interests and practice in ways that indirectly and directly supported the mobilization of German society for Nazi purposes of conquest and war. 
DROB, Sanford Lewis. 'Jung, Kirsch, and Judaism. Mystical and Paradoxical Transformations.' Jung Journal: Culture E Psyche 6, 1 (2012): 35-55.

In this article, the author explores several themes that emerge from the correspondence between C.G. Jung and his Jewish disciple, James Kirsch, focusing on their discussions of Jung's purported anti-Semitism, and their exchanges on the Lurianic Kabbalah and related developments in Jewish mystical theology. Letters between Jung and Kirsch that treat the relationship between the Jews and Christ are placed in the context of those that consider Jung's interpretation of the Kabbalah. The question of Kirsch's relationship to Jung, Jung's 1944 "Kabbalistic Visions," the ensuing transformation in Jung's attitude toward Judaism, and the reasons for his late-life claim that a Hasidic rabbi, the Maggid of Mezirich, anticipated his entire psychology, are explored. Finally, the author offers his reflections on Jung's "paradoxical affinity" to Judaism and the contemporary relationship between Judaism and Jungian psychology.

\section{EVENO, Bertrand. 'Les "arabesques multicolores" de Jung, expressions et significations} dans le vocabulaire pictural du Livre Rouge.' Cahiers jungiens de psychanalyse 136 (novembre 2012): 51-71.

Paintings say more than what they seemingly show. Jung's pictorial vocabulary as a painter is not gratuitous, and deserves closer study. After experimenting with several styles, both naive and academic, Jung developed his "multicolored arabesques" quite extensively. He enjoyed producing numerous virtuoso variations on the theme. Possibly, these paintings are a representation in figurative language of the unconscious and the archetypes, subjects that are impossible to describe or portray, in either words or images.

FAlzeder, Ernst. 'Review of Elke MEtzner and Martin Schimkus, Die Gründung der Internationalen Psychoanalytischen Vereinigung durch Freud und Jung. LuziferAmor 25, 49, (2012): 173-175.

\section{GaILlard, Christian. 'The egg, the vessels and the words. From Izdubar to Answer to} Job. Form an imaging thinking.' Journal of Analytical Psychology 57, 3 (June 2012): 299-334.

This essay on The Red Book seeks to underscore a characteristic specific to Jung's approach to psychoanalysis. In this book, and more generally, in all of his writings, Jung's thinking is based on his personal experience of the unconscious, in which he leaves himself open to progressive encounters. Some of them, in the years 1913-14 and 1929-30, particularly his meeting with the giant Izdubar, were quite threatening. As a result, he forged an original way of thinking that is qualified here as 'imaging' and 'emergent'. The Red Book served as the first vessel for theories Jung would later express. His way of thinking, with its failures and semi-successes, all of which are always temporary, of course, is compared to the art of the potter. The author shows the kinship between the formation of the main Jungian concepts and the teachings of the French poet, professor, and art critic Yves Bonnefoy. He also considers certain recurrent formal themes in the work of contemporary German painter and sculptor Anselm Kiefer. Lastly, this epistemological study, constantly aware of the demands of Jungian clinical practice, demonstrates the continuity in Jung's work, from The Red Book to Answer to Job, where Jung ultimately elaborated a conception of history that defines our ethical position today.

\footnotetext{
KIRSCH, Thomas. 'Jung and his relationship to Judaism.' Jung Journal: Culture E Psyche 6 (2012): 10-20.

Jung's relationship to Judaism and to Jewish psychology has been a subject of great controversy. In the last two years, four books have been published that have brought to light new primary documents on Jung's relationship to Judaism, showing a change in his view from the 1930 s to one more sympathetic to the mystical traditions within Judaism. This paper discusses the four books-Kabbalistic Visions, The Red Book, Carl Gustav Jung: Avant-Garde Conservative, and The Jung-Kirsch Letters-with special reference to the correspondence between the author's father, James Kirsch, and Jung.
}

\section{KREIS, Georg. 'Besichtigung eines Krisenkomplexes C. G. Jung im historischen Kontext} der 1930er Jahre.' Analytische Psychologie 168, 43, 2 (2012): 200-15.

English translation: 'Survey of a crisis complex: C. G. Jung in historical contexts of the 1930s.' Jung Journal: Culture \& Psyche 6, 4 (2012): 12-24.

This contribution aims at recalling the contemporary context of some statements made by C. G. Jung at a time that is considered problematic today. It is not about justifying these statements, since a strong personality and scholar like Jung is responsible for himself, but rather about focusing on the interplay between influences coming from the Zeitgeist on its contemporaries and the influences of the contemporaries on the Zeitgeist. For them, the diagnosis of crisis may have been not only alarming but also welcome because it allowed for the promulgation of a remedy for overcoming it. Several aspects of crisis potentially reinforced each other, but they are separately identifiable. One can distinguish among economic, political, and cultural crises, also among the diagnoses of crisis in these respective fields. 
Switzerland was successful in overcoming the sense of crisis in its society in the area of national defense before the outbreak of war in 1939.

LAmmers, Ann Conrad. 'Professional relationships in dangerous times: C. G. Jung and the Society for Psychotherapy.' Journal of Analytical Psychology 57 (2012): 99119 .

Relying in part on previously unpublished documents of the 1930s, this paper describes the origins and mission of the General Medical Society for Psychotherapy, both as it existed before Hitler's rise to power and as it was transformed afterward. Jung accepted the Society's presidency in 1933-34, on condition that it be restructured as an international, politically neutral organization, free from the laws of Gleichschaltung (Nazi conformity). The paper also contains a close study of Jung's collaboration with one interesting German colleague, Walter Cimbal. Cimbal, a neurologist, was briefly a member of the Nazi Party and, judging from his early letters to Jung, a Hitler enthusiast. Yet he also seems to have tried, together with Jung, to alleviate the difficulties of German Jewish colleagues whose lives were disrupted by the Hitler revolution. The paper includes translated passages from Cimbal's previously unpublished letters from 1933-36 and the post-war years. It also includes a first-person account by Wladimir Rosenbaum, the Zurich lawyer who assisted Jung in 1934, when Jung tried to mitigate the impact of anti-Jewish laws on his German Jewish colleagues. In the primary materials of this period one discovers more evidence of moral shadow-and also less-than is sometimes assumed.

LAmmers, Ann Conrad. 'James Kirsch's religious debt to C. G. Jung.' Jung Journal: Culture E Psyche 6, 1 (2012): 21-34.

Due in part to his published statements in 1933-1934, Jung fell into disrepute with many Jews in Europe and Palestine (Israel). In a series of essays and letters written from Tel Aviv in 1934, James Kirsch, one of Jung's first German-Jewish followers, defended him energetically against accusations of anti-Semitism. Kirsch argued that Jung's early encounters with Freud had given him a distorted, "exilic" view of Judaism. He maintained that Jung's psychology, not Freud's, offered healing to modern Jews tragically cut off from The Holy, which has always spoken in dreams and other communications from the unconscious.

LAMmers, Ann Conrad. 'Hoffnung in der Verbannung: James Kirschs Verteidigung von C. G. Jung, 1934' Analytische Psychologie 168, 43, 2 (2012): 182-99.

LuPO, Luca. “'Also spricht meine Seele”. Lo Zarathustra di Nietzsche nel Libro rosso di Jung: la verità come vita tra esperienza ed esperimento.' In GORI, Pietro and Paolo STELLINO (eds.). Teorie e pratiche della verità in Nietzsche. Pisa: ETS, 2012.

SHAmDaSAnI, Sonu. 'Introduction.' In Jung, C. G. Introduction to Jungian Psychoogy. Notes of the Seminar on Analytical Psychology Given in 1925. Princeton: Princeton University Press, 2012: ix-xxiii.

French translation: 'Introduction.' In JUNG. C. G. Introduction à la psychologie jungienne. Le séminaire de psychologie analytique de 1925, Paris: Albin Michel, 2015: 11-29.

\section{SORGE, Giovanni. 'Jungs Präsidentschaft in der Internationalen Allgemeinen Ärztlichen} Gesellschaft für Psychotherapie. Neue Erkenntnisse.' Analytische Psychologie 168, 43, 2 (2012): 152-81.

Jung's activities during the Thirties in the institutional field of psychotherapy as well as some affirmations concerning the Jewish and German collective mentality have given rise to a historiographical debate that is today still very live and controversial. Often the debate is polarized between accusers and defenders on the basis of a rather static historical investigation of the primary sources. This paper deals, with the help of some unpublished material, mainly with Jung's activity in the AAGP - the IAAGP (1933-1939/40). In his position as president of the Society, Jung faced difficulties due to the strong political presence of the German psychotherapeutic Society, and he tried to create other national groups in the framework of a Federal supernational or international and neutral Society. The main focus here is given to the initial phase of the Jung's presidency in 1933, his initial position when faced with the question of the Gleichschaltung of the German Group (DAAGP), and then to the Congresses of the following years and the development of psychotherapy in Europe before the Second World War.

English translation: 'Jung's Presidency of the International General Medical Society of Psychotherapy. New Insights' Jung Journal: Culture and Psyche 6, 4 (Fall 2012): 31-53. 
SMYTHE, William E. and Angelina BAYDALA. 'The hermeneutic background of C. G. Jung.' Journal of Analytical Psychology 57, 1 (February 2012): 57-75.

Hermeneutics has been central to the practice of Jung's psychology from the beginning, although he never fully and consistently developed a hermeneutic method of inquiry and the literature addressing this aspect of his psychology is not extensive. In this paper we undertake a critical re-examination of Jung's relationship to hermeneutic thought, based on his explicit references to hermeneutics in the Collected Works and his theoretical development of the notion of archetypes. Although Jung did not consistently formulate a hermeneutic approach to inquiry, his theoretical development of archetypes is rich in hermeneutic implications. In particular, his notion of the archetype as such can be understood hermeneutically as a form of non-conceptual background understanding. Some implications of this construal of archetypes for Jungian hermeneutics as a form of inquiry are considered.

RASCHE, Jörg. 'C. G. Jung in den 1930er Jahren. Nicht idealisieren, aber auch nicht verkleinern.' Analytische Psychologie 168, 43, 2 (2012): 216-37.

This article reflects on C. G. Jung's political behavior during the early years of Nazi dictatorship. Beginning with a consideration by Gershom Scholem, Jung's medical and therapeutic attitude in the 1933 Berlin seminar and the collective psychic disorientation during the Weimar period are analyzed. The article also focuses on German perfection, the dangerous mythologizing of politics, and Jung's relationship with Zionism. The author recommends reconsidering shadow projections.

English translation: 'C. G. Jung in the 1930s: not to idealize, neither to diminish.' Jung Journal: Culture E Psyche 6, 4 (2012): 54-73.

\section{SHAMDASANI, Sonu. 'After Liber Novus.' Journal of Analytical Psychology 57 (2012): 364-}

\section{7.}

This paper reflects on the conference question concerning the clinical and theoretical significance of Jung's Liber Novus, two years after its initial publication, and looks at how Jung himself reflected upon it and how it informed his turn to alchemy, with particular attention to the theme of opposites and their reconciliation in Liber Novus, later taken up in Mysterium Coniunctionis.

Schoent, William, and Danielle Peck. 'An Answer to the Question: was Jung, for a Time, a “Nazi Sympathizer" or not?' Jung Journal: Culture E Psyche 6, 4 (2012): 98-105.

In this paper, we show that it is untenable to hold that Jung was a 'Nazi sympathizer' after May 1934. Jung went through a decisive transition from March to May 1934 in which he became warier of the Nazis. It remains possible, however, to argue that between January 1933 and February 1934 he either was or was not in some degree a Nazi sympathizer. From 1934 to 1936, he became still warier of the Nazis. By March 1936, his attitude toward the Nazis took a further turn: it was clearly more pessimistic than in 1935. Thus, Jung's views of Nazi Germany changed from 1933 to 1936.

\section{3}

$\underline{B o o k s}$

Hillmann, James and Sonu ShamDaSAni. Lament of the Dead. Psychology after Jung's Red Book. New York: W. W. Norton \& Company, 2013.

RIBI, Alfred. The Search for Roots. C. G. Jung and the Tradition of Gnosis. Los Angeles, Salt Lake City: Archive Books, 2013.

StePhenson, Craig E. Jung and Moreno: Essays on the Theatre of Human Nature. London, New York: Routledge, 2013.

SENGUPTA, Sulagna. Jung in India. New Orleans: Spring Journal Books, 2013. 
BARROS GEWEHR, Rodrigo. 'La mort comme significant de rupture. Une lecture des racines du désaccord entre Freud et Jung.' Cahiers jungiens de psychanalyse 137 (mai 2013): 159-75.

This essay tries to add some arguments about the disagreements between Freud and Jung. As the history of depth psychology has shown us, these two researchers approached, even built a friendship and then lose each other, both personally and theoretically. Several reasons have been pointed out for this breakdown, but we believe that there are still a few pieces to add, especially regarding the epistemological and ontological aspects involved in their theoretical relationship. In other words, have their views on the nature of the psyche played a role in the difficulties that led to the end of their collaboration? We try to provide some answers through their correspondence, specially emphasizing the relation between theoretical developments and their personal relationship. Death, ultimately, means the impossible in this association.

BARROS GEWEHR, Rodrigo. 'L'inconscient phylogénétique versus l'inconscient collectif. Contribution au dialogue entre Freud et Jung.' Revue de psychologie analytique, 1,1 (2013) 75-97.

In the field of depth psychology, the agreements and disagreements between Freud and Jung have become well-known, and the quarrels between the two have had repercussions on both post-Freudians and post-Jungians. Nevertheless, we have also been able to observe openings that promote some dialogue between these two approaches to the study of the human psyche. Among them is consideration of the ancestral. Indeed, both Freud and Jung worked on the notion of the ancestral by way of the concepts of, respectively, a phylogenetic unconscious and a collective unconscious. As their manners of conceiving the ancestral are so different, one may wonder if this approach is truly precise, or justifiable. More specifically, while for Freud repression remains the condition for and the guarantee of a phylogenetic unconscious, for Jung this condition appears as partial ; and the very idea of an archetype throws doubt on Freud's insistence upon the oedipal complex as the ultimate explanation of the process of cultural transmission. Our goal is to study these two concepts so as to better understand the role of ancestry in both Freud's and Jung's work. We are also seeking to understand if the ancestral is more a meeting point or one of separation between these two authors, in particular given Freud's claim that the collective unconscious is an unnecessary or superfluous concept.

BeEbE, John and Ernst FAlzeder. 'Introduction.' In The Question of Psychological Types: The Correspondence of C. G. Jung and Hans Schmid-Guisan 1915-1916. Princeton, Oxford: Princeton University Press, 2013: 1-32.

GaILlard, Christian. 'Jung, Picasso et le bleu.' Revue de psychologie analytique 1, 1 (2013): 33-73.

In September 1932, the first large retrospective exhibition of Picasso's art opened at the Kunsthaus in Zurich. Jung was one of the visitors, and he was at once struck, and moved, by what he discovered there. He was particularly impressed by Picasso's works in blue although these were few in number in this exhibit. From this experience, he wrote an essay that was published in the Neue Zürcher Zeitung. Also in 1932, just prior to the article on the exhibit, Jung wrote an essay on Joyce's Ulysses. Through his analysis of these two essays written by Jung, the author shows how Jung takes the opposite point of view from those with Freudian approaches to the arts, inscribing his own position in the aftermath of his experience of writing and painting in the Red Book. He also shows Jung to be far from the anti-modern individual he is often made out to be. And he stresses the manner in which Jung, following his meeting with Wilhelm and before the work he will do on alchemical iconography and literature, inaugurates and develops observations and reflections in these essays that may be found in one of today's most fruitful orientations of the psychoanalysis of art : one which focuses on the different phases, often critical, of the creative process itself. Blue is thus revealed as a particular moment of a specific process. The author notes this particularity of Jung's thoughts concerning "process", how Jung perceives it from a 'long term' perspective, that is to say he considers the transformations to be ongoing, not only at the level of a work of art or of a life, but also at the level of the history of a culture, our own.

GAY, Marco and Isolde SCHIFFERMÜLLER (eds.). Lo Zarathustra di Nietzsche: C. G. Jung e lo scandalo dell'inconscio. Bergamo: Moretti \& Vitali, 2013.

GRAF-NOLD, Angela. "Das fremde Psychische objektiv erfassen" - Carl Gustav Jung am Burghölzli 1900-1909.' In RÖSSLER, Wulf, and Hans DANUSER (eds.). Burg aus Holz; Das Burghölzli: Von der Irrenanstalt zur Psychiatrischen Universitätsklinik. Zürich: Verlag Neue Zürcher Zeitung, 2013: 62-9. 
HAANING, Aksel. 'Jung's quest for the Aurora Consurgens.' Journal of Analytical Psychology 59, 2014, 8-30.

The paper focuses on the year 1929, when Jung publishes An European Commentary to Richard Wilhelm's German translation of the Taoist text The Secret of the Golden Flower, and shows that Jung is on the track for possible European alchemy by Konrad Waldkirch's preface in Artis Auriferae (1593); it asks if this is the possible missing link for Jung's research in Alchemy and Hermetic Philosophy in the years to come. It argues that here begins Jung's quest for the Aurora consurgens, which publication concludes the Mysterium Coninctionis more than twenty years later. Further is argued, that the choice of Aurora is in deep connection with Jung's ambition of revitalizing the past from within the individual and is explained by Jung's deep concern with the welfare and future of modern society.

French translation: 'La quête de Jung de l'Aurora Consurgens.' Revue de psychologie analytique 1, 2 (2013): 73103.

MAILlard, Christine. “Kâlî est Salomé et Salomé est mon âme”. La référence à l'Inde dans Le Livre Rouge (1914-1930) de Carl Gustav Jung et dans sa pensée psychologique des années 1910 et 1920.' In MAILlard, Christine, and Rajan REKHA (ed.). Les intellectuels européens et l'Inde au XXe siècle. Strasbourg, Presses Universitaires de Strasbourg, 2013: 69-92.

\section{MiLLS, Jon. 'Jung's metaphysics.' International Journal of Jungian Studies 5, 1 (2013): 19-} 43.

Despite it being the focal point of his theoretical system, I argue that Jung's notion of the archetypes is one of his least understood concepts because it was nebulous to Jung himself. Jung vacillated between viewing archetypes as analogous to primordial images and ideas inherited from our ancestral past, formal a priori categories of mind, cosmic projections, emotional and valuational agencies, and numinous mystical experience, but the question remains whether a 'suprapersonal' or 'transubjective' psyche exists. In what follows, I will be preoccupied with tracing the theoretical development of Jung's thesis on the collective unconscious, with a special emphasis on the archetypes, and hence pointing out the metaphysical implications of his thought. It is not possible to critique his entire body of work in the context of this abbreviated article; therefore, the reader should be aware that I am limiting myself to a narrow scope of interest in explicating and analyzing the philosophical viability of his major concepts. The greater question is whether the archetypes adequately answer to the question of origins, of an omnipresent and eternal dimension to the nature and structure of psychic reality.

RITSKE, Rensma. 'Analytical psychology and the ghost of Lamarck: did Jung believe in the inheritance of acquired characteristics?' Journal of Analytical Psychology 58, 2 (April 2013): 258-77.

Whether Jung was a Lamarckian or not has always been a hotly debated topic, both within the post-Jungian community and amongst scholars with an interest in Jung in the wider academic community. Yet surprisingly few substantial pieces of work have been dedicated to it and, to my mind, no one has yet managed to do justice to all the subtleties involved. The scholars who have claimed that Jung is a Lamarckian have, for the most part, oversimplified the debate by failing to discuss the passages in which Jung appears to be defending himself against Lamarckism; the scholars who have defended Jung against Lamarckism, however, have as a rule not adequately dealt with the question of whether these passages actually get Jung off the hook. This paper will attempt to correct this imbalance by putting forward four key passages spanning Jung's career that all represent conclusive evidence that Jung was indeed a Lamarckian. After discussing these, it will then deal in detail with the passages in which Jung appears to be defending himself against Lamarckism, making the case that they do not represent a defence against Lamarckism at all and have therefore generally been misinterpreted by many scholars.

SERINA, Florent. '“La structure de l'âme” de C. G. Jung (Genève, juin 1928).' Revue de Psychologie Analytique 1, 1 (2013): 176-96.

This study is an historical presentation of a long lost conference given in French by C. G. Jung on June 14, 1928, at the Permanent Center for International Conferences and Congresses on Psychical Research in Geneva, and published in the 1928 November-December issue of the Revue Métapsychique. The author first exposes the different steps of Jung's thought processes and then proceeds to give a description of their context and an analysis of the contents, following which he brings to light their specificities. 
SERINA, Florent. “J'ai eu connaissance par le journal”. Synchronicité et actualités.' Cahiers jungiens de psychanalyse 137 (mai 2013): 15-25.

According to Sonu Shamdasani, C. G. Jung's works on synchronicity are an attempt to understand his dreams and visions related to World War One in scientific terms. This historical study, devoted to the appearance of phenomena of significant coincidence in C. G. Jung's life, aims to enrich Shamdasani's hypothesis with elements that have not yet been introduced to the discussion.

SERINA, Florent. 'La question du rêve comme point de rupture entre l'École de Zurich et Sigmund Freud.' Cahiers jungiens de psychanalyse 138 (novembre 2013): 21-40.

In 1909, C.G. Jung wrote "The analysis of dreams." The author pursues a commentary on it, showing that the period leading up to and culminating in the split between Zurich and Vienna was marked by a lively debate on the socalled 'prospective' function of the dream suggested by Alphonse Maeder.

\section{4}

Books

Arocha Herrera, Alejandro. C. G. Jung y la tradición hermética. Salamanca: Publicaciones Universidad Pontificia, 2014.

BisHOP, Paul. Carl Jung. London: Reaktion Books, 2014.

FABJ, Luca Valerio. Jung e la fenomenologia: $i$ vissuti psicopatologici fondamentali. Volume primo, La patologia della percezione dell'oggetto e le precezioni extrasensoriali. Bologna : Paolo Emilio Persiani, 2014.

Hauf, Monika. Bollingen: C. G. Jungs steinernes "Symbol der Wandlung”. Ein Rätsel wird entschlüsselt. Neustadt an der Orla: Telesma-Verlag, 2014.

VIELJEUX, Juliette, and Florent SERINA, Bibliographie raisonnée des écrits de C. G. Jung en allemand, anglais et français, avec des avant-propos de Ulrich HOERNI et de Sonu SHAMDASANI. Paris: Le Martin-Pêcheur / Domaine jungien, 2014.

Articles, introductions, book chapters and reviews

BERNARDINI, Riccardo. 'Jung nel giardino di Eranos: il paesaggio dell'analisi.' In VignA, Ferruccio (ed.). L'Ombra del Flâneur. Scritti in onore di Augusto Romano. Bergamo: Moretti \& Vitali, 2014: 35-46.

BiSHOP, Paul. “Natur und Kunst, Sie scheinen sich zu fliehen, / Und haben sich”- im Roten Buch? - "gefunden".' Recherches germaniques hors-série 9 (2014): 99-113.

BuRSTON, David Raphael. "Our imperiled age”: an unfinished dialogue between Carl Jung and Karl Stern.' International Journal of Jungian Studies 6, 3 (2014): 18o-88.

Karl Stern was a Catholic psychiatrist in Montreal who published extensively on psychoanalysis and religion from 1951 to 1965 . He sent a copy of his second book, The Third Revolution (1954) to Jung, who responded warmly in a (hitherto unpublished) letter dated 30 April 1960. The paper ponders the similarities and differences between Stern and Jung's approach to the psychology of religion, and the impact that Jung's belated response to Stern's book might have had on Stern subsequently. 
CIFALI, Mireille. 'Rencontres de Carl Gustav Jung avec Théodore Flournoy. De l'occulte à la psychose.' Le Coq-Héron 218 (2014): 72-80.

Derrière la rupture entre Jung et Freud en 1913, il y a la présence de Théodore Flournoy. Entre Jung et Flournoy, des intérêts communs pour l'occulte, l'imagination créatrice, le religieux. Entre Jung et Freud, la dementia praecox et la paranoïa. L'article trace quelques correspondances entre ces trois hommes et les événements auxquels ils ont été mêlés.

DE MourA, Vicente. 'Learning from the patient: The East, synchronicity and transference in the history of an unknown case of C. G. Jung.' Journal of Analytical Psychology 59, 3 (2014): 391-409.

This article presents the history of one until now unknown case of C.G. Jung: Maggy Reichstein. Born in Indonesia in 1894 in a very aristocratic family, she brought her sister to Zurich to be treated by Jung in 1919, and later she herself was in analysis with him. Jung used her case as example in his lecture in 1937 on the realities of practical psychotherapy, relating it to the process of transference and countertransference. Jung deepened his studies in Eastern psychology after a series of dreams she had, which culminated in the Yoga Kundalini Seminars. She was also the case presented in his article of 1951 on the concept of synchronicity. Jung wrote that her case, concerning synchronicity, remained unique in his experience. Jung also published some of her mandalas. He considered her able to understand his ideas in depth. Reichstein was for Jung an important case, which challenged and triggered his interests in different subjects.

DomenicI, Gaia. 'Overleaping oder Surpassing? Die problematische Lektüre der Geschichte des Seiltänzers bei C. G. Jung.' In ATES, Murat (ed.). Nietzsches Zarathustra Auslegen. Thesen, Positionen und Entfaltungen zu Also sprach Zarathustra von Friedrich Wilhelm Nietzsche. Marburg: Tectum Verlag, 2014: 207-19.

FALZEDER, Ernst. 'Review of Paul BISHOP, Carl Jung'. The Journal of Analytical Psychology 59, 5, (2014): 716-17.

GIESER, Suzanne. 'From Copenhagen to the consulting room: Pauli and Jung in Copenhagen.' Journal of Analytical Psychology 59, 2 (March 2014): 165-73.

In this paper the city of Copenhagen is used as a starting point to highlight some critical historical events, both concerning the exchange of ideas between the physicist Wolfgang Pauli and C.G. Jung and the history of psychotherapy in Scandinavia. Pauli's years in Copenhagen under the influence of Niels Bohr and his philosophy prepared him mentally to receiveC.G. Jung's ideas. The paper also recounts the one occasion that Jung was in Scandinavia, attending the 9 th conference of the General Medical Society for Psychotherapy in Copenhagen, just before going to New York in 1937 to give his final seminars on Pauli's dreams. The reason for focusing on these particular events is that they also constitute part of the history of the reception of psychodynamic psychology in Sweden and Scandinavia.

GUMPPER, Stéphane. “Schize” numineuse et scansions, via le corpus jungien (19021930): vers une suppléance par l'écriture?" Recherches germaniques hors-série 9, (2014): 115-33.

JeHle-Wildberger, Marianne. 'Die Wegstrecke von den Anfangen - Der Briefwechsel zwischen Jung und Keller." In C. G. Jung und Adolf Keller. Über Theologie und Psychologie: Briefe und Gespräche. Zurich: Theologischer Verlag, 2012: 11-128.

LAGORIO, Silvia. 'Jung e Eliade. La rivelazione della nozze e della morte.' Rivista di psicologia analitica 89, 37 (2014): 227-36.

LIARD, Véronique. 'Zeitgeist et "Esprit des profondeurs" dans les images du Livre Rouge.' Recherches germaniques hors-série 9 (2014): 135-51. 
LIEBSCHER, Martin. 'Schopenhauer und Jung.' In SchubBe, Daniel and Matthias KossLer (eds.). Schopenhauer-Handbuch. Leben, Werk, Wirkung. Stuttgart: Metzler, (2014): 312-16.

LuDWIG-KÖRNER, Christiane. 'Antonia Francesca Sussmann geb. Borchardt, eine vergessene Jungianerin.' Analytische Psychologie 45, 178 (2014): 422-43.

MAIN, Roderick. 'The cultural significance of synchronicity for Jung and Pauli.' Journal of Analytical Psychology 59, 2 (April 2014): 174-80.

This paper considers the cultural significance of C.G. Jung's concept of synchronicity, as this was envisaged both by Jung himself and by the physicist Wolfgang Pauli, Jung's most important discussant in developing the concept. For both thinkers the principle of synchronicity was, above all, an attempt to develop an expanded, more holistic understanding of science. The paper argues, however, that their motives for proposing this development were not just, as might be expected, scientific, philosophical, and psychological (including personal), but also historical, social, political, and religious, and involved consideration of esoteric as well as mainstream currents of thought.

MAILlARD, Christine and Véronique LIARD. 'Réévaluer l'oeuvre de Jung?' Recherches germaniques hors-série 9 (2014): 1-5.

MÀDERA, Romano. 'Empirisme ou une philosophie pour l'âme? Réflexions sur la pensée de C. G. Jung.' Recherches germaniques hors-série 9 (2014): 43-61.

MAILlaRd, Christine. 'Herbert Silberer (1882-1923) et Carl Gustav Jung: genèse et enjeux d'une théorie de l'alchimie.' Recherches germaniques hors-série 9 (2014): 79-97.

SchMITT, Gerhard. 'Wahrheit und Individuation - zum verlauf von Denklinien bei Heidegger und Jung.' Recherches germaniques hors-série 9 (2014): 239-56.

Schoent, William. 'Jung's evolving Views of Nazi Germany: From 1936 to the end of World War II.' Journal of Analytical Psychology 59, 2 (2014): 245-62.

This article first shows Jung's evolving views of Nazi Germany from 1936 to the beginning of World War II. In a lecture at the Tavistock Clinic, London, in October 1936, he made his strongest and most negative statements to that date about Nazi Germany. While in Berlin in September 1937 for lectures to the Jung Gesellschaft, his observations of Hitler at a military parade led him to conclude that should the catastrophe of war come it would be far more and bloodier than he had previously supposed. After the Sudetenland Crisis in Fall 1938, Jung in interviews made stronger comments on Hitler and Nazi Germany. The article shows how strongly anti-Nazi Jung's views were in relation to events during World War II such as Nazi Germany's invasion of Poland, the fall of France, the bombings of Britain, the U.S. entry into the War, and Allied troops advancing into Germany. Schoenl and Peck, 'An Answer to the Question: Was Jung, for a Time, a "Nazi Sympathizer" or Not?' (2012) demonstrated how his views of Nazi Germany changed from 1933 to March 1936. The present article shows how his views evolved from 1936 to the War's end in 1945.

SORGE, Giovanni. 'Die Theorie der "Mana-persönlichkeit” im jungschen Werk. Eine historisch-hermeneutische Perspektive.' Recherches germaniques hors-série 9 (2014): 205-37.

VON GURETZKY, Bernhard. 'Zur Begriffsgeschichte der Synchronizität.' Analytische Psychologie 175 (2014): 56-83.

Seit einigen Jahren nimmt das Interesse am Begriff der Synchronizität zu. Der Begriff wird damit verstärkt kontrovers diskutiert. Der vorliegende Text sucht dessen philosophische und psychologischen Wurzeln auf und zeichnet nach, wie Jung zur Idee seiner revolutionären Begriffsbildung kam. Dazu gehört eine kritische Analyse dessen, wie sich bei Jung das Verständnis dessen, was er mit Synchronizität umschrieb, im Laufe von über 30 Jahren verändert hat. Dies ist nicht nur von begriffshistorischem, sondern auch von therapeutischem Interesse, insbesondere für Themen wie Sinn und Zeit. 
Domenici, Gaia. Books 'for All and None'. Nietzsche's Zarathustra, Jung's The Red Book, and 'Visionary Works'”. PhD dissertation, University of Pisa, 2015.

Owens, Lance S. Jung in Love: The Mysterium in Liber Novus, Los Angeles: Gnosis Archive Books, 2015.

Articles, introductions, book chapters and reviews

BARreto, Marco Heleno. 'Remarks on the meaning of “irrational” in Jung.' Jung Journal: Culture \& Psyche 9, 1 (2015): 31-41.

Jung's conception of 'reason'-and thus of what is 'rational' and 'irrational'-is decisive in its consequences to psychology, both theoretically and practically. No matter how one much one protests against the misappropriation of Jung by magical and superstitious currents in the panoply of contemporaneous ideologies, one must concede that Jung himself could be charged with being responsible for this use of his thought. In this paper, I examine briefly the meaning of 'irrational' in Jung, so that the nature of the 'irrationalism' stemming from his position can be contrasted with the "irrationalism" of the common magical appropriations of his thought.

Bernardini, Riccardo. 'In analisi con Jung: I diari di Emma von Pelet.' Rivista di psicologia analitica 91, 39 (2015): 219-36.

BoubliL, Élodie. 'C. G. Jung, lecteur de Zarathoustra: penser l'individuation chez Nietzsche.' BÉLAND, Martine (ed.) Lectures nietzschéennes, sources et receptions. Montréal: Presses de l’Université de Montréal, 2015: 337-65.

CoHEn, Betsy. 'Dr. Jung and his patients.' Jung Journal: Culture E Psyche 9, 2 (2015): 39-49.

The author studied the total of Jung's 236 clinical cases, as described in The Collected Works and 1925 Seminars. She questions whether Jung was a relational psychoanalyst, as he describes himself in many of his theoretical writings about psychotherapy. She discovers that only eight examples include discussion of his relationship with the patient from a relational perspective. Dr. Cohen looks carefully at two of Jung's well-known cases, those of Kristine Mann and Wolfgang Pauli, and examines why Jung separates the personal and archetypal (objective) psyche in his analysis with them.

Domenici, Gaia. 'Il “ruggito del leone morale”. C. G. Jung si confronta con Zarathustra.' In D’IORIO, Paolo, Maria Cristina FORNARI, Luca LUPO, and Chiara PIAZZESI (eds.). Prospettive. Omaggio a Giuliano Campioni. Pisa: ETS, 2015: 201-o6.

Hieronimus, Gilles. 'Culture de soi ou advenir du Soi? Éléments pour une confrontation entre G. Bachelard et C. G. Jung.' Cahiers Gaston Bachelard 13: (2015): 29-47.

KENNY, Robert. 'Freud, Jung and Boas: the psychoanalytic engagement with anthropology revisited.' Notes and records of the Royal Society of London 69, 2 (June 2015): 173-90.

Sigmund Freud's and C. G. Jung's turn to evolutionist anthropological material after 1909 is usually seen as a logical progression of their long-term interest in such material. It is also seen that they used this material ignorant of the significant challenges to the evolutionist paradigm underpinning such material, in particular the challenges led by 
Franz Boas. This paper argues otherwise: that both psychologists' turnings to such material was a new development, that neither had shown great interest in such material before 1909, and that their turnings to such material, far from being taken in ignorance of the challenges to evolutionist anthropology, were engagements with those challenges, because the evolutionist paradigm lay at the base of psychoanalysis. It argues that it is no coincidence that this engagement occurred after their return from America in 1909, where they had come into first-hand contact with the challenges of Franz Boas.

KeVE, Tom. 'The Jung-Ferenczi dossier.' American Journal of Psychoanalysis 75, 12 (March 2015): 94-109.

The acquaintance between Sándor Ferenczi and C. G. Jung pre-dates their first encounter with Sigmund Freud. Later, a triangular relationship developed when the three men crossed the Atlantic together and spent an extended period in one another's company. Ferenczi's friendship with Jung could not survive the latter's break with Freud, but its development between 1907 and 1913 is evidenced by unpublished letters from Jung to Ferenczi, found in the Ferenczi Archive, now at the Freud Museum.

LAUNER, John. 'Carl Jung's relationship with Sabina Spielrein: a reassessment.' International Journal of Jungian Studies 7, 3 (2015): 179-93.

The aim of this article is to give an accurate account of the relationship between Sabina Spielrein and Carl Gustav Jung, based on a close reading of the available documentary evidence. I challenge many of the commonly held assumptions about their relationship. These include the belief that Spielrein was Jung's first analytic patient, that they had a long and mutually passionate affair, and that Spielrein was the inspiration behind Jung's conception of the 'anima'. I argue that there is little evidence for these and a number of other beliefs that have been passed down through successive cultural iterations without careful documentary analysis.

LiARD, Véronique. 'Le Livre Rouge de C. G. Jung. L'expérience d'une nouvelle forme de spiritualité.' S. Crinquand, P. Bravo, Au plus profond de soi: quand le spirituel se fait intime. Louvain-la-Neuve: EME Éditions, 2015: 72-86.

LIEBSCHER, Martin. 'Introduction.' In Analytical Psychology in Exile: The Correspondence of C. G. Jung and Erich Neumann. Princeton, Oxford: Princeton University Press, Philemon Series, 2015: xi-lxi.

German version : 'Einleitung.' C. G. Jung - Erich Neumann. Die Briefe, 1933-1959: Analytische Psychologie im Exil. Ostfildern: Schwaben, 2015: 10-59.

French translation : 'Introduction.' In C. G. Jung, E. Neumann, Correspondance. Zurich-Tel Aviv (1933-1959). Paris: La Compagnie du Livre Rouge, Imago, 2018: 9-52, translated by B. Eveno.

LIEBSCHER, Martin. 'Le lettere di C. G. Jung a Erich Neumann nell'edizione rivisitata alla luce della corrispondenza Jung-Neumann.' Enkelados 3 (2015): 47-70.

LiebsCHER, Martin. 'Review of Paul Bishop, Carl Jung.' History of Human Sciences 28, 4 (2015): 102-105.

Quaglino, Gian Piero, and Augusto Romano, Riccardo Bernardini, 'Introduction.' In Jung, C. G. The Solar Myths and Opicinus de Canistris. Notes of the Seminar given at Eranos in 1943. Einsiedeln: Daimon Verlag, 2015: 13-76.

SHAMDASANI, Sonu. "S. W." and C. G. Jung: mediumship, psychiatry and serial exemplarity.' History of Psychiatry 26, 3 (2015): 288-302.

On the basis of unpublished materials, this essay reconstructs Jung's seances with his cousin, Helene Preiswerk, which formed the basis of his 1902 medical dissertation, The Psychology and Pathology of so-called Occult Phenomena. It separates out Jung's contemporaneous approach to the mediumistic phenomena she exhibited from his subsequent sceptical psychological reworking of the case. It traces the reception of the work and its significance for his own self-experimentation from 1913 onwards. Finally, it reconstructs the manner in which Jung continually returned to his first model and reframed it as an exemplar of his developing theories. 
StePhenson, Craig E. On Psychological and Visionary Art: Notes From C. G. Jung's Lecture on Gérard de Nerval's Aurélia. Princeton, Princeton University Press, 2015: 1-48.

French translation: 'À propos de l'art psychologique et visionnaire. Commentaires sur la conférence de Jung sur Aurélia, de Gérard de Nerval, tenue en 1945.' Revue de psychologie analytique 5, (2016): 8-41, translated by C. Raguet.

STEIN, Leslie. 'Jung and divine self-revelation.' Jung Journal: Culture E Psyche 9, 1 (2015): 18-30.

The Seven Sermons to the Dead provides what Jung called the "supreme meaning" of his opus, which is the reconciliation of opposites. However, his choice of a Pleroma in the Sermons that consists of both fullness and nothingness hints at a deeper meaning veiling a mystical vision he must have had but never revealed. In choosing to follow Basilides's concept of a Pleroma, the deeper meaning, as asserted in this paper, is divine self-reflection: making the purpose of individuation to become an instrument through which the divine can witness its own creation. It was not until Answer to Job that Jung referred to man as being the "instrument into which God enters to attain selfreflection" but that mystical vision is exposed in the Sermons and, therefore, informed his later work.

\section{6}

$\underline{B o o k s}$

VAN DER BERK, Tjeu. In de ban van Jung. Nederlanders ontdekken de analytische psychologie. Zoetermeer: Uitgeverij Meinema, 2016.

BISHOP, Paul. On the Blissful Islands with Nietzsche and Jung: In the Shadow of the Superman. London: Routledge, 2016.

Chemouni, Jacquy. Savoir ou révélation. La mythologie entre Freud et Jung. Paris: Les Belles Lettres, 2016.

DoHe, Carrie B. Jung's Wandering Archetype: Race and Religion in Analytical Psychology. London, New York: Routledge, 2016.

ESCAMILLA, Michael. Bleuler, Jung and the Creation of the Schizophrenias. Einsiedeln: Daimon Verlag, 2016.

Roesler, Christian. Das Archetypenkonzept C. G. Jungs: Theorie, Forschung und Anwendung. Stuttgart: Verlag W. Kohlhammer, 2016.

Shalit, Erel, and Murray STEIN (eds.). Turbulent Times, Creative Minds - Erich Neumann and C. G. Jung in Relationship (1933-1960). Asheville: Chiron, 2016.

Schoent, William and Linda SchOent, Jung's Evolving Views of Nazi Germany. From the Nazi Takeover to the End of World War II. Asheville: Chiron Publications, 2016.

Sorge, Giovanni. Psicologia analitica e Anni Trenta. Il ruolo di C. G. Jung nella 'Internationale Allgemeine Ärztliche Gesellschaft für Psychotherapie' (19331939/40). Dissertation, Universität Zürich 2010/2016. 
BARTON, David G. 'C. G. Jung and the indigenous psyche: two encounters.' International Journal of Jungian Studies 8, 2 (2016): 75-84.

In The Lament of the Dead, James Hillman quotes Foucault as saying there are two ways to escape 'the box of contemporary thinking'. One path lies through erudition, the other through the indigenous experience. While the history of Jung's ideas has been thoroughly explored, we understand little about his encounters with indigenous people in the American Southwest. For example, the literature on his visit to Taos Pueblo is riddled with misleading information. Part of the problem begins with Jung's own confusion regarding his contact at Taos with Antonio Mirabal. Not only did Jung wrongly believe that Mirabal was an 'Indian chief; he misspelled and mistranslated his Tiwa name, Ochwiay Biano. Although the encounter could be described (at one level) as superficial, Jung refers to it as one of the most important experiences of his life. This paper will explore what Jung seems to have encountered in Taos, and the ways his experience were orchestrated by the unseen presence of others (including Mabel Dodge Lujan, D. H. Lawrence, and Jaime de Angulo). Archival records and news accounts from the 1920s show that although Jung imagined he was meeting face to face with a 'primitive' who still lived in the world of 'participation mystique', Mirabal was a gifted Native American impresario who later visited one American president and turned down an invitation to visit a second. I argue that the complex of colonialism surrounding Jung's relationship with Mirabal has infected subsequent encounters between the Jungian tradition and indigenous people.

\section{BisHOP, Paul. 'Eine "Kathedrale des Geistes”? Spiritualität und Ästhetik in Jungs Rotem Buch.' Analytische Psychologie 47, 186 (2016): 431-52. \\ In a conversation with Christiana Morgan on 12 July 1926 Jung is said to have advised her to put her visions down »as beautifully as you can - in some beautifully bound book «. Why ought she to do this? »When these things are in some precious book«, Jung continued, "you can go to the book and turn over the pages and for you it will be your church - your cathedral - the silent places of your spirit where you will find renewal«. How seriously was this advice to be taken? And to what extent is Jung's Red Book to be understood as a psychological, as a philosophical, or as a reli- gious document? This contribution considers various ways of thinking about spirituality that are expressed in the Red Book; not least in relation to Jung's own later intellectual development.}

\section{CY, Kim. 'Carl Gustav Jung and Granville Stanley Hall on Religious Experience.' Journal of Religious Health 55, 4 (August 2016): 1246-6o. \\ Granville Stanley Hall (1844-1924) with William James (1842-1910) is the key founder of psychology of religion movement and the first American experimental or genetic psychologist, and Carl Gustav Jung (1875-1961) is the founder of the analytical psychology concerned sympathetically about the religious dimension rooted in the human subject. Their fundamental works are mutually connected. Among other things, both Hall and Jung were deeply interested in how the study of religious experience is indispensable for the depth understanding of human subject. Nevertheless, except for the slight indication, this common interest between them has not yet been examined in academic research paper. So this paper aims to articulate preliminary evidence of affinities focusing on the locus and its function of the inner deep psychic dimension as the religious in the work of Hall and Jung.}

\section{CROCE, Francesca, 'Attraverso l'immagine. Il processo trasformativo di Atmavictu- Philemon nel Libro rosso di C. G. Jung. Prima parte.' l'Ombra 8 (2016): 47-63.}

\footnotetext{
FALZEDER, Ernst. 'Types of truth. Jung's philosophical roots.' Jung Journal: Culture $\mathcal{E}$ Psyche 10, 3 (2016): 14-30.

This paper investigates Jung's position vis-à-vis science and philosophy. It is argued that Jung tried, in his writings, to find a superior standpoint, from which he could view, and explain, what he perceived as man's precarious position between two extreme poles, or different "truths." Among his attempts to do so was not only his typology of 1921, but also, in fact, three other attempts at a typological classification, so that we could speak of a quaternity of typologies.
}

GITZ-JOHANSEN, Thomas. 'Jung in education: a review of historical and contemporary contributions from analytical psychology to the field of education.' Journal of Analytical Psychology 61, 3 (June 2016):365-84.

The available literature on the influence of Jungian thought on the theory and practice of education leaves the impression that although the work of Carl Jung and analytical psychology have much to offer the field of education, the Jungian influence has so far been slight. While this has certainly been true, the last decade or so has nevertheless witnessed an increased scholarly interest in exploring how analytical psychology may inform and inspire the field of education. As an explanation for this burgeoning interest in Jung, several of the contemporary contributors mention that analytical psychology has the potential of functioning as a counterbalance to the tendencies in Western societies to focus on measurable learning targets and increasingly standardized measures of teaching and assessment. It seems 
pertinent then to gain an overview of how analytical psychology has so far inspired the field of education and how it may fruitfully continue do so in the future. To this end this paper is structured chronologically, starting with the different phases of Jung's own engagement with the field of education and ending with later post-Jungian applications of his concepts and ideas to education.

GRAF-NOLD, Angela. 'Switzerland's “Intimate Tragedy” - C. G. Jung's “Basic Roughness” / Count Keyserling's Encounter with Jung and Switzerland.' In RASCHE, Joerg, and Thomas Singer (eds.). Europe's Many Souls: Exploring Cultural Complexes and Identities. New Orleans, Spring Journal Books, 2016: 189-210.

In 1928, ten years after the end of World War I, as the crisis in Europe was buliding, Count Keyserling published his book 'The Spectrum of Europe', where he portrays the European nations, stating and validating their specific characters within Europe. Concerning Switzerland he stated an 'intimate tragedy': an anti-aristocratic country, small, narrow, ingnificant, the Swiss: conventional, ugly, without principles, miserly. Only two well known Swiss personalities stood out as positive examples: Hans Badrutt, the pioneer of Swiss luxury hotel business, and C. G. Jung. Undoubtedly Keyserling diagnosed some specific Swiss cultural complexes: the anti-authoritarian and anti-aristocratic mental attitude of the Swiss, the limited space, the political neutrality and the specific relationship with money. His onesided negative view of these pecularities obviously was complying with his personal situation as an uprooted impoverished Baltic aristocrate, a victim of World War I. And since he doesn't analyse the Swiss myths nor the historical facts of Swiss history, Keyserling's diagnosis doesn't provid an orientation; his view rather mirrors the cultural and political tensions in Europe that would erupt soon tragically in World War II.

LIARD, Véronique. 'Carl Gustav Jung et Friedrich Hölderlin.' Cahiers jungiens de psychanalyse 144, 2 (novembre 2016): 11-28.

C. G. Jung felt that as a poet, Hölderlin had brought him even more than even Goethe, but what he valued in Hölderlin's poetry was essentially psychological in nature. He noted that the poems retrace how a consciousness which does not evolve gradually sinks into its own depth, and slowly finds itself submerged by the unconscious. In Jung's writings, he regularly refers to Hölderlin as both a warning and a message of hope. This alert and encouragement are based on what Jung himself experienced in his confrontation with the unconscious.

LIEBSCHER, Martin. 'Uncertain Friends in Particular Matters.' In SHALIT, Erel, and Murray SteIN (eds.). Turbulent Times, Creative Minds: Erich Neumann and C. G. Jung in Relationship (1933-1960). Asheville, North Carolina: Chiron Publications, 2016: 25-44.

LIEBSCHER, Martin: 'The challenges of editorship: a reflection on editing the JungNeumann correspondence', in Journal of Analytical Psychology 61, 2 (2016): 15571.

MAILLARD, Christine. 'Le Livre Rouge (1914-1930) de Carl Gustav Jung: individuation et discours sur l'éthique.' Danger et nécessité de l'individuation IX Colloque de Bruxelles. Noville-sur-Mehaigne, Maransart: Esperluète/L'Arbre Soleil, 2016: 7698. Republished in Cahiers jungiens de psychanalyse 147 (juin 2018): 15-32.

Peltier, Armelle Line. 'Le Livre Rouge de Carl Gustav Jung: processus créateur et connaissances.' Delforge, Nicolas and Matthias DÖRRIES (ed.). Limites de la créativité. Paris: Kimé, 2016: 129-50.

Schoenl, William, and Linda Schoent, 'Jung's views of Nazi Germany: the first year and Jung's transition.' Journal of Analytical Psychology 61, 4 (September 2016): 481-96.

This article first considers Jung's response to the coming to power of the Nazis in Germany. It brings forth evidence that, besides wanting to preserve psychotherapy in Germany and maintain the international connection between the German and other communities of psychotherapists, he wanted to advance Jungian psychology - his psychology - in Germany. It also presents evidence that, although he occasionally made some anti-Semitic statements during this early period, he was not anti-Semitic in the way the Nazis were. The paper then argues that after Gustav Bally's criticisms in the Neue Zuercher Zeitung in February 1934, Jung entered into a transitional period that spring 
during which he became warier both of the Nazis and of making any statements that could be construed as being antiSemitic. Schoenl and Peck (2012) have shown how Jung's views of Nazi Germany changed from 1933 to March 1936. This present article demonstrates very significant changes in Jung's views during the important early part of this period, that is from January 1933 - when Hitler became Chancellor of Germany - through to the spring of 1934. It draws on evidence from archival and other primary sources.

ShamDASAnI, Sonu. 'Descensus ad Infernos: la saison en enfer de C. G. Jung.' Danger et nécessité de lindividuation. IX Colloque de Bruxelles. Noville-sur-Mehaigne, Maransart: Esperluète/L'Arbre Soleil, 2016: 27-76.

SERINA, Florent. 'Le cas Miss Miller, de Théodore Flournoy à Carl Gustav Jung.' Cahiers jungiens de psychanalyse 144 (novembre 2016): 11-28.

In 1990, Sonu Shamdasani pierced some of the mysteries surrounding a key figure in the history of analytical psychology, the woman named Miss Frank Miller. This new edition of her self-observations - in English - is an opportunity not only to delve into certain aspects of her biography, but also to reexamine the way they were interpreted by Théodore Flournoy, and later Carl Gustav Jung.

\section{7}

Books and doctoral dissertations

BAILEY, David. The English Woman and C. G. Jung. London: Austin Macauley Publishers, 2017.

BisHOP, Paul. On the Blissful Islands with Nietzsche E Jung: in the Shadow of the Superman. London, New York: Routledge, Taylor \& Francis Group, 2017.

Boechat, Walter. The Red Book of C.G. Jung: a Journey into Unknown Depths, preface by Sonu Shamdasani. London: Karnac, 2017, translated from the Brazilian by C. Hoggarth.

BOnARDEL, Françoise. Jung et la Gnose. Paris: Pierre Guillaume de Roux, 2017.

CLAY, Catherine. Labyrinths: Emma Jung, her Marriage to Carl and the Early Years of Psychoanalysis. London: William Collins, 2017.

JeHLE-WiLdBerger, Marianne. 'Stationen einer schwierigen Freundschaft - C. G. Jung und Adolf Keller.' In SchweIzer, Andreas, and Regine ScHWEIZER-VÜLLERS (eds.). Baustein. Reflexionen zur Psychologie von C. G. Jung. Einsiedeln: Daimon Verlag, 2017: 255-278.

English translation: 'Stations of a difficult relationship - Carl Gustav Jung and Adolf Keller.' In SCHWEIZER, Andreas, and Regine SCHWEIZER-VÜLLERS (eds.). Stone by Stone. Reflections on the Psychology of C. G. Jung, Einsiedeln: Daimon Verlag, 2017: 241-263.

LIENHART, Sonja Theresa. Das Religionsverständnis von Sigmund Freud und Carl Gustav Jung. Gießen: Psychosozial-Verlag, 2017.

MAgGY, Anthony. Salome’s Embrace: the Jungian Women. Abingdon, Oxon, New York: Routledge, 2017. 
Maillard, Christine. Au cœur du Livre Rouge. Les Sept Sermons aux Morts. Paris: Imago, La Compagnie du Livre Rouge, 2017.

Savage, Nan Healy. Toni Wolff \& C. G. Jung: A Collaboration. Los Angeles: Tiberius Press, 2017.

SERINA, Florent. Carl Gustav Jung en France au XXe siècle. Histoire d'une reception. Thèse pour l'obtention du grade de docteur ès lettres, Faculté des lettres de l'Université de Lausanne - Institut Universitaire d'Histoire de la Médecine et de la Santé Publique, 2017.

SpARKS, J. Gary. Carl Jung and Arnold Toynbee: The Social Meaning of Inner Work, Toronto: Inner City Books, 2017.

\section{Articles and book chapters}

FIKE, Matthew A. 'C. G. Jung on plagiarism in Pierre Benoît's L'Atlantide.' International Journal of Jungian Studies 9, 3 (2017): 167-82.

Jung explained the possible plagiaristic relationship between Henry Rider Haggard's She and Pierre Benoit's L'Atlantide as either cryptomnesia or archetypal inspiration, but he was misinformed about the case and unfamiliar with Benoît's life. This essay critiques Jung's statements about Benoît and then considers the case for plagiarism that was published in The French Quarterly in 1919-1920. Neither the typical reply - that L'Atlantide reflects the author's African experience and historical knowledge - nor the reading of the novel that arose from Jung's 1925 seminar adequately refutes the plagiarism charge. A depth-psychological reading of L'Atlantide shows the danger of seeking the anima archetype itself rather than experiencing the anima in a relationship with an available woman. But even if literary analogies, including the Circe myth, suggest that Haggard and Benoît may have tapped into the same archetypal vein, the novels' similarities and verbal echoes cannot be dismissed outright.

SERINA, Florent. 'Rêver de C. G. Jung. Extraits des carnets de rêves d'Hélène Kiener.' Cahiers jungiens de psychanalyse 146 (décembre 2017): 45-58.

How should a historian rank the dream notebooks of an analysand and a psychotherapist? How is he entitled to use them? These questions are discussed here, to introduce a selection of oneiric writings, taken from the notebooks of Hélène Kiener, an Alsatian student of C. G. Jung.

SHAMDASANI, Sonu. 'Des névroses à une nouvelle cure des âmes: C. G. Jung et la refonte du patient thérapeutique.' Cahiers jungiens de psychanalyse 146 (décembre 2017): 7-28.

This paper studies how from the First World War onwards, C. G. Jung reformulated his psychotherapeutic procedure on the basis of his own self-experimentation. It shows how through doing so, he shifted the aims of psychotherapy from being solely the cure of pathology to one of higher psychological and spiritual development, and in so doing, proposed a new notion of humanity. It studies a series of cases of Jung, demonstrating how he reformulated the 'offer' of psychotherapy, how individuals took it up, and how this helped to shape the social role of the psychotherapeutic patient.

WOOLFSON, Tony. "I came across this impressive doctrine”. Carl Gustav Jung, Gershom Scholem, and Kabbalah.' In SchwEIZER, Andreas, and Regine SCHWEIZER-VÜLLERS (eds.). Stone by Stone. Reflections on the Psychology of C. G. Jung. Einsiedeln: Daimon Verlag, 2017: 135-70. 


\section{8}

Books

Ammann, Ruth, Verena KAST, and Ingrid RIEDEL (ed.). Das Buch der Bilder: Schätze aus dem Archiv des C. G. Jung-Instituts Zürich. Ostfildern: Patmos Verlag, 2018.

Hoerni, Ulrich, Thomas Fischer, Bettina Kaufmann, and the Foundation OF THE Works OF C. G. Jung, The Art of C. G. Jung. New York: W. W. Norton and Company, 2018.

Italian translation: L'arte di C. G. Jung, Torino: Bollati Boringhieri, 2018, translated by M. A. Massimello.

Greene, Liz. The Astrological World of Jung's 'Liber Novus': Daimons, Gods, and the Planteray Journey. London, New York: Routledge, 2018.

MeLLICK, Jill, The Red Book Hours: Discovering C. G. Jung's Art Mediums and Creative Process. Zürich: Scheidegger and Spiess, 2018.

Articles and introductions

Baumann, Daniel. 'Réflexion sur la creation de la tour de Bollingen.' Jung et l'élan créateur. $X^{e}$ Colloque de Bruxelles. Noville-sur-Mehaigne, Maransart: Esperluète/L'Arbre Soleil, 2018: 31-64.

BERNARDINI, Riccardo. 'Jung nelle Nuove Edizioni Ivrea (NEI). Con la corrispondenza inedita C. G. Jung - Cesare Musatt/NEI'. l'Ombra 9 (2018): 167-200.

Falzeder, Ernst. 'Introduction to Volume 1.' In JUnG, C. G. History of Modern Psychology. Lectures delivered at ETH Zurich, volume I, 1933-1934. Princeton: Princeton University Press, 2018: xxxiii-l.

Falzeder, Ernst, Martin LiebsCher and Sonu Shamdasani. 'General Introduction.' In JunG, C. G. History of Modern Psychology. Lectures delivered at ETH Zurich, volume I, 1933-1934. Princeton: Princeton University Press, 2018: xix-xxvii.

HOERNI, Ulrich. 'Foreword: C. G. Jung's Activities at ETH Zurich'. In JUnG, C. G. History of Modern Psychology. Lectures delivered at ETH Zurich, volume I, 19331934. Princeton: Princeton University Press, 2018: vii-xviii. Translated from the German by H. McCartney.

LIARD, Véronique. 'Grande Mère et Ourobouros patriarcal. Dépendance et indépendance du féminin chez Erich Neumann.' Cahiers jungiens de psychanalyse 147 (juin 2018): 67-80. 
Owens, Lance S. 'C. G. Jung and Erich Neumann: The Zaddik, Sophia, and the Shekinah.' Psychology.' Psychological Perspectives 61, 2 (2018): 133-51.

Erich Neumann was one of C. G. Jung's most brilliant and creative disciples. Publication in 2015 of the correspondence between Neumann and Jung-Analytical Psychology in Exile: The Correspondence of C. G. Jung and Erich Neumann-has opened new perspectives on the work of both men. Neumann stated that his encounter with Jung, initiated in 1933, was the transformative event in his life. He perceived Jung to be the living exemplar of a Zaddik. Eventually Neumann helped Jung better understand the mystical depths of Jewish tradition. Each man affirmed that the vital task awaiting the coming age was a re-valorization of the feminine archetype of divinity, traditionally identified both as Sophia and as the Shekhinah in Kabbalistic tradition.

Perugini, Alessandra. 'La buccia di un segreto. Giacomo Debenedetti e Carl Gustav Jung.' l'Ombra 9 (2018): 229-65.

\section{PRIVIERO, Tommaso. 'Jung and the quest for creative imagination.' European Yearbook} of the History of Psychology 4 (2018): 135-55.

In this paper, I intend to explore the roots of Jung's psychological elaboration of the ancient notion of active imagination. The revalorisation of a creative and healing function of imagination was central throughout Jung's life and work. In the first place, it was crucial in Jung's visionary experiment known as Liber Novus [New Book]. Later, it played a primary role in the progressive adaptation of active imagination as a therapeutic tool in analytical psychology. At the same time, an increasing interest in the creative faculties of imagination was in the early decades of the twentieth century the object of a cultural, cross-disciplinary discussion which affected the intersection between psychology and terrains such as art and literature. In this paper, I aim to offer a brief survey of the way in which Jung's reflection on the nature of imagination was underpinned by the experimental lines of such cultural moment.

ROMANO, Augusto. 'Bobi Bazlen e Jung.' l'Ombra 9 (2018): 201-10.

RYALS, Samuel L. 'Miss Frank Miller: Jung’s Sherpa from Alabama.' Quadrant: The Journal of the C. G. Jung Foundation. XLVIII: 1 (Summer 2018): 25-40.

The life of Miss Frank Miller has been examined by two Jung historians, Sonu Shamdasani and Florent Serina. Miller was the subject of Carl Jung's 1912 Transformations and Symbols of the Libido and his 1952 revision, Symbols of Transformation. Though their research took the Miller mysteries out of the Stygian darkness, key genealogical questions remained about her childhood and death. This article fills in gaps about her childhood and argues that Jung's reading of the Miller Fantasies was an important event during his watershed studies of mythology.

SERINA, Florent. 'A case of undeclared debt? Claude Levi-Strauss' ambiguities and paradoxes toward analytical psychology.' Journal of the History of the Behavioral Sciences 54, 3 (Summer 2018): 163-77.

If his relationship to Sigmund Freud's psychoanalysis has been widely acknowledged, Claude Lévi-Strauss' rapport with C. G. Jung's analytical psychology remains quite obscure. While secondary commentary has been abundant, its approach has above all been intertextual, to the detriment of a rigorously historical reading. Even if certain arguments put forward by supporters of so-called 'influence' deserve to be taken into account, especially because they highlight Lévi-Strauss ambiguities and paradoxes toward Jung, this paper provides proof that a precise reading of the texts, with the help of recent studies on the intellectual genesis of Lévi-Strauss, lead to reject the thesis of an unstated debt owed by the French anthropologist to the Zurich psychologist.

SERINA, Florent. 'Henri Ey sur la voie d'une relecture organo-dynamique de l'originaire jungien.' Les Cahiers Henri Ey 41-42 (juin 2018): 169-92.

SHAMDASANI, Sonu. 'Expressions symboliques: Jung, Dada, le mandala et l'art de la folie.' Jung et l'élan créateur. $X^{e}$ Colloque de Bruxelles. Noville-sur-Mehaigne, Maransart: Esperluète/L'Arbre Soleil, 2018: 269-324. 